\title{
Emission factors for open and domestic biomass burning for use in atmospheric models
}

\author{
S. K. Akagi ${ }^{1}$, R. J. Yokelson ${ }^{1}$, C. Wiedinmyer ${ }^{2}$, M. J. Alvarado ${ }^{3}$, J. S. Reid ${ }^{4}$, T. Karl ${ }^{2}$, J. D. Crounse ${ }^{5}$, and \\ P. O. Wennberg 6 \\ ${ }^{1}$ University of Montana, Department of Chemistry, Missoula, MT, USA \\ ${ }^{2}$ National Center for Atmospheric Research, Boulder, CO, USA \\ ${ }^{3}$ Atmospheric and Environmental Research (AER), Inc., Lexington, MA, USA \\ ${ }^{4}$ Naval Research Laboratory, Monterey, CA, USA \\ ${ }^{5}$ Division of Chemistry and Chemical Engineering, California Institute of Technology, Pasadena, CA, USA \\ ${ }^{6}$ Divisions of Engineering and Applied Science and Geological and Planetary Science, California Institute of Technology, \\ Pasadena, CA, USA
}

Received: 19 September 2010 - Published in Atmos. Chem. Phys. Discuss.: 12 November 2010

Revised: 14 April 2011 - Accepted: 15 April 2011 - Published: 3 May 2011

\begin{abstract}
Biomass burning (BB) is the second largest source of trace gases and the largest source of primary fine carbonaceous particles in the global troposphere. Many recent BB studies have provided new emission factor (EF) measurements. This is especially true for non-methane organic compounds (NMOC), which influence secondary organic aerosol (SOA) and ozone formation. New EF should improve regional to global $\mathrm{BB}$ emissions estimates and therefore, the input for atmospheric models. In this work we present an up-to-date, comprehensive tabulation of EF for known pyrogenic species based on measurements made in smoke that has cooled to ambient temperature, but not yet undergone significant photochemical processing. All EFs are converted to one standard form (g compound emitted per kg dry biomass burned) using the carbon mass balance method and they are categorized into 14 fuel or vegetation types. Biomass burning terminology is defined to promote consistency. We compile a large number of measurements of biomass consumption per unit area for important fire types and summarize several recent estimates of global biomass consumption by the major types of biomass burning. Post emission processes are discussed to provide a context for the emission factor concept within overall atmospheric chemistry and also highlight the potential for rapid changes relative to the scale of some models or remote sensing products. Recent work
\end{abstract}

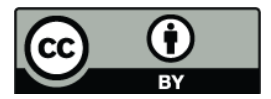

Correspondence to: R. J. Yokelson

(bob.yokelson@umontana.edu) shows that individual biomass fires emit significantly more gas-phase NMOC than previously thought and that including additional NMOC can improve photochemical model performance. A detailed global estimate suggests that $\mathrm{BB}$ emits at least $400 \mathrm{Tg} \mathrm{yr}^{-1}$ of gas-phase NMOC, which is almost 3 times larger than most previous estimates. Selected recent results (e.g. measurements of $\mathrm{HONO}$ and the BB tracers $\mathrm{HCN}$ and $\mathrm{CH}_{3} \mathrm{CN}$ ) are highlighted and key areas requiring future research are briefly discussed.

\section{Introduction}

Biomass burning (BB) can be broadly defined as open or quasi-open combustion of any non-fossilized vegetative or organic fuel. Examples range from open fires in forests, savannas, crop residues, semi-fossilized peatlands, etc. to biofuel burning (e.g. cooking fires, dung burning, charcoal or brick making, etc.). Savanna fires, domestic and industrial biofuel use, tropical forest fires, extratropical (mostly boreal) forest fires, and crop residue burning are thought to account for the most global biomass consumption (in the order given). Overall, BB is the largest source of primary fine carbonaceous particles and the second largest source of trace gases in the global atmosphere (Bond et al., 2004; Andreae and Merlet, 2001; Forster et al., 2007; Guenther et al., 2006).

Published by Copernicus Publications on behalf of the European Geosciences Union. 
Particles emitted and formed in BB plumes have major direct and indirect effects on climate (Hobbs et al., 1997; Rosenfeld, 1999) and contribute to dense continental-scale haze layers that occupy much of the tropical boundary layer (and sometimes large parts of the boreal boundary layer) during the dry season (Andreae et al., 1988; Reid et al., 1998; Wofsy et al., 1992; Eck et al., 2003). A multipart review by Reid et al. (2005a, b) focused on the physical and optical properties of biomass burning particles and their impacts. These topics have been the subject of much ongoing research (e.g. Andreae et al., 2004; Ramanathan and Carmichael, 2008; Grieshop et al., 2009).

The trace gases emitted by biomass burning have a significant influence on the atmosphere, which includes a major contribution to the formation of global tropospheric ozone $\left(\mathrm{O}_{3}\right)$, an important greenhouse gas (Sudo and Akimoto, 2007). The $\mathrm{O}_{3}$ formed can also affect air quality: e.g. Pfister et al. (2007) show that BB emissions from California wildfires in 2007 increased downwind ozone concentrations in rural regions. Trace gases from $\mathrm{BB}$ can contribute to the secondary formation of aerosol particles (Reid et al., 1998; Alvarado and Prinn, 2009; Yokelson et al., 2009). The effect of BB trace gases on the oxidizing power of the troposphere is an important, complex issue. The hydroxyl radical $(\mathrm{OH})$ is a key oxidant in the global troposphere and is mostly produced in the tropics, which is also where $\sim 70-80 \%$ of BB is thought to occur (Crutzen and Andreae, 1990; van der Werf et al., 2010). The carbon monoxide (CO) and NMOC produced by $\mathrm{BB}$ are continually removed via reaction with $\mathrm{OH}$ while photolysis of some of the oxygenated NMOC and the $\mathrm{O}_{3}$ formed in BB plumes can be an $\mathrm{OH}$ source (Crutzen and Andreae, 1990; Singh et al., 1995). Coupled with this picture are large tropical biogenic emissions of isoprene, which has a complex oxidation scheme that is still under investigation, but results in some $\mathrm{OH}$ regeneration and significant $\mathrm{CO}$ production (Lelieveld et al., 2008; Paulot et al., 2009; Archibald et al., 2010; Peeters et al., 2009)

Among the earliest studies to point out the importance of biomass burning on the global scale are the seminal work of Crutzen et al. (1979) and Seiler and Crutzen (1980). Major field campaigns in the 1980's and 1990's resulted in a boom in BB related publications. These are well summarized in a number of review and compilation papers, such as Haywood and Boucher (2000), Andreae and Merlet (2001), Simoneit (2002), Lemieux et al. (2004), and Reid et al. (2005a, b). The work of Andreae and Merlet (2001), in particular, continues to have widespread use in the atmospheric modeling community. For example, the emission factors (EF or EFs, the grams of a compound emitted per $\mathrm{kg}$ of dry biomass burned) reported therein can be combined with databases that provide estimates of global biomass consumption such as Global Fire Emissions Database (GFED, van der Werf et al., 2006, 2010) and Fire Locating and Modeling of Burning Emissions (FLAMBE, Reid et al., 2009), to produce emission estimates for atmospheric models. De- spite the continued utility of previous reviews, a large number of studies have been carried out since $\sim 2000$ that benefitted from advances in instrumentation and the understanding of BB plume chemistry. The results of these studies have not been conveniently compiled in one work. Thus, to aid in the assessment of biomass burning impacts in model simulations, we present an updated compilation with the following rationale:

1. In recent years, the ability has been developed to quantify a wide range of emitted species that were previously unmeasured and thus, often ignored in modeling applications.

2. The effect of rapid plume chemistry on measured emission ratios is better understood. This has led to recognition of the need to compare or combine data from smoke samples of a similar well-defined age in a standardized way. Our compilation of "initial" EF is based on measurements made in smoke that has cooled to ambient temperature, but not yet undergone significant photochemical processing.

3. Many of the studies compiled in this work sampled smoke meeting the "freshness" criteria above and measured a wide range of species from a large number of fires. Studies that are more comprehensive and of fresher smoke may better represent the true regional initial emissions. These EF measurements need to be compiled for convenient use in atmospheric models to promote improved modeling results and assessments.

4. With computational capacity increasing and to promote a wide variety of applications, the link between the fire emissions and the fire type needs to be available at a high level of detail, but still allow straightforward implementation of less detailed schemes. The difference between fire types is small for the EF of some species, but can be quite large for others.

5. Methods need to be developed for dealing with the abundant, but as yet unidentified NMOC, which strongly impact plume chemistry.

6. The calculation of emission rates requires emission factors to be linked to estimates of biomass consumption. Thus we also compile a large number of measurements of biomass consumption per unit burned area for major fire types and several estimates of global biomass consumption by the main fire types.

7. The emission factor tables will be updated when warranted and available at: http://bai.acd.ucar.edu/Data/ fire/.

In this paper we assess the literature on BB emission factors to address the above issues. We organized the available data into 14 different categories based on the type of fuel 
burned and then analyzed each study considering the different properties of the sampled fires (e.g. amount of flaming and smoldering), the attributes of the measuring platforms, instrument sensitivity, and the number of fires sampled. We carefully selected measurements in smoke roughly 5-20 min old, after immediate condensational processes on smoke particles yet prior to most of the photochemistry that can alter the composition of a plume. The age of the smoke sample is important, since current photochemical plume models and larger-scale global atmospheric chemistry models (GACMs) use the emissions as direct inputs before chemical changes occur. Despite the difficulty of modeling rapid changes occurring after emission, initial emission measurements obtained in fresh smoke, as described above, may provide the only clearly defined point in smoke evolution for a bottom-up approach. We also briefly discuss measurements in aged smoke separately to summarize our knowledge of post-emission chemistry, which is both complex and so variable that a single EF for an advanced smoke age would be highly uncertain for most species emitted by BB. This work presents a comprehensive effort tying together recent measurements of emission factors, fuel loadings, plume chemistry, and global BB estimates for the main types of biomass fires to facilitate improved understanding of regional/global tropospheric chemistry.

\section{Methods and results}

\subsection{Terminology and the scope of this compilation}

\subsubsection{Emission ratios, emission factors and combustion efficiency}

An excess mixing ratio (EMR) is defined as the mixing ratio of species $\mathrm{X}$ in smoke minus its mixing ratio in background air. The EMR of $X$ is often denoted by " $\Delta X$," where the measured value reflects the degree of plume dilution and the instrument response time (Andreae et al., 1988; Yokelson et al., 1999). As a standardization measure, $\Delta \mathrm{X}$ is often divided by an EMR of a fairly non-reactive co-emitted smoke tracer $(\Delta \mathrm{Y})$, such as $\mathrm{CO}$ or $\mathrm{CO}_{2}$; this molar ratio is defined as the normalized excess mixing ratio (NEMR), which can be measured anywhere within a plume. A special case of the NEMR is the "emission ratio" (ER); the molar ratio between two emitted compounds (also written as $\Delta \mathrm{X} / \Delta \mathrm{Y}$ ), which should be reserved for emission measurements taken at the source (fresh smoke). The NEMR is highly variable for reactive gases and some aerosol species downwind from fires, and is dependent on the details of the post-emission processing (see Sect. 3.5). Thus for a reactive compound, a NEMR measured downwind may not be equal to the emission ratio even though it is expressed in similar fashion. A simpler alternative term sometimes used to refer to downwind NEMR is the "enhancement ratio" (Lefer et al., 1994), but since it would have the same abbreviation as "emission ratio" and some species are "depleted" downwind, we do not use this term in this work.

We use ERs to derive EFs in units of grams of $\mathrm{X}$ emitted per kilogram of dry biomass burned using the carbon mass balance method (Ward and Radke, 1993) with explicit equations shown elsewhere (e.g. Yokelson et al., 1999). The method assumes that all burned carbon is volatilized or contained in the emitted aerosol and that all major carboncontaining species have been measured. The inability to detect all carbon species can inflate emission factors by $1-2 \%$ when using the carbon mass balance method (Andreae and Merlet, 2001). The carbon content in the fuel must also be measured or estimated. In this study we assume a $50 \%$ carbon content by mass (dry weight) when a measured value is not available. Except for organic soils and dung, the carbon content of biomass normally ranges between 45 and 55\% (Susott et al., 1996; Yokelson et al., 1997; McMeeking et al., 2009). EF scale linearly in proportion to the assumed fuel carbon fraction. Our calculation of EF from charcoal kilns (in units of $\mathrm{gX}$ per $\mathrm{kg}$ charcoal made) reflects the changing carbon content during the kiln lifetime, as detailed by Bertschi et al. (2003a) and briefly discussed in Sect. 2.3.9.

Combustion efficiency (CE) - the fraction of fuel carbon converted to carbon as $\mathrm{CO}_{2}$ - can be estimated from measured emission ratios with the detailed equation given elsewhere (e.g. Sinha et al., 2003). The CE at any point in time during a fire, or for the fire as a whole, depends strongly on the relative contribution of flaming and smoldering combustion, with a higher CE indicating more flaming (Ward and Radke, 1993; Yokelson et al., 1996). Flaming combustion involves rapid reaction of $\mathrm{O}_{2}$ with gases evolved from the solid biomass fuel and is common in foliage or dry, small diameter aboveground biomass. Flaming combustion converts the $\mathrm{C}, \mathrm{H}, \mathrm{N}$, and $\mathrm{S}$ in the fuel into highly oxidized gases such as $\mathrm{CO}_{2}, \mathrm{H}_{2} \mathrm{O}, \mathrm{NO}_{\mathrm{x}}$, and $\mathrm{SO}_{2}$, respectively, and produces most of the black (or elemental) carbon particles. As a fire progresses, smoldering combustion tends to play a more dominant role via both surface oxidation (also known as "glowing" or gasification) and pyrolysis (mostly the thermal breakdown of solid fuel into gases and particles), often affecting large-diameter aboveground biomass and belowground biomass. Smoldering produces most of the $\mathrm{CO}, \mathrm{CH}_{4}$, NMOC, and primary organic aerosol. Smoldering and flaming frequently occur simultaneously during a fire, and distinct combustion phases may not occur. Flaming $(\sim 1400 \mathrm{~K})$ and glowing $(\sim 800-1000 \mathrm{~K})$ are the two heat sources driving pyrolysis and fuel temperatures can range from unheated to that of a nearby heat source. The widely used term "fire temperature" is based on the amount of 4-micron radiation emitted by a geographic area containing a fire and may not reflect the relative amount of flaming and smoldering (Kaufman et al., 1998). We also note that smoldering is not caused by a deficiency of $\mathrm{O}_{2}$; rather chemisorption of $\mathrm{O}_{2}$ on char is exothermic and helps drive glowing combustion (Yokelson 
et al., 1996). Depletion of $\mathrm{O}_{2}$ was measured at only a few percent or less within intense, open fires and $\mathrm{O}_{2}$ levels may not have a large affect on the gas-phase species emitted by fires (Susott et al., 1991). Large natural variability in fuel geometry, growth stage, moisture, windspeed, etc. causes large natural variability in the relative amount of biomass consumption by flaming and smoldering combustion; even within a single fire type category. This, coupled with variation in fuel chemistry, leads to a large range in the naturally occurring EF for most species for any fire type as discussed more below.

The combustion efficiency, as stated above, can be useful in indicating the relative abundance of flaming and smoldering combustion. Since CE is hard to measure, the modified combustion efficiency (MCE), which is defined as $\Delta \mathrm{CO}_{2} /\left(\Delta \mathrm{CO}_{2}+\Delta \mathrm{CO}\right)$, is commonly reported as an estimate of CE accurate within a few percent (Ferek et al., 1998). Pure flaming has an MCE near 0.99 while the MCE of smoldering varies over a larger range $(\sim 0.65-0.85)$, but is most often near 0.8. Thus an overall fire-integrated MCE near 0.9 suggests roughly equal amounts of biomass consumption by flaming and smoldering. Since both CE and MCE indicate the relative amount of flaming and smoldering combustion, both parameters often correlate reasonably well with EF (Fig. 4.3 in Ward and Radke, 1993; Fig. 3 in Yokelson et al., 2003). For example, in Fig. 3 of Yokelson et al. (2003) airborne measurements of $\mathrm{EF}\left(\mathrm{CH}_{4}\right)$ for individual fires range from $\sim 0.5 \mathrm{~g} \mathrm{~kg}^{-1}$ to $\sim 3.5 \mathrm{~g} \mathrm{~kg}^{-1}$ (a factor of 7) with decreasing MCE. Additional variation in EF and MCE would result from considering the unlofted emissions from residual smoldering combustion (RSC) (see, e.g., Bertschi et al., 2003b; Christian et al., 2007; Yokelson et al., 2008). In general, the MCE dependence of "EF(X)" for a fire type allows calculation of a specific $\mathrm{EF}(\mathrm{X})$ for any known MCE. However, we do not yet have good data on how regional average MCE may evolve with time over the course of the biomass burning season for the major types of burning. Thus, in this work we only report average EF for each fire type and (where possible) a very rough estimate of the expected naturally occurring range in the average EF appropriate for a typical group of fires. The calculation of these values is described in detail in Sect. 2.3.

\subsubsection{NMOC, OVOC, and NMHC}

Non-methane hydrocarbons (NMHC) are defined as organic compounds excluding methane $\left(\mathrm{CH}_{4}\right)$ that contain only $\mathrm{C}$ and $\mathrm{H}$; examples include alkanes, alkenes, alkynes, aromatics, and terpenes. Oxygenated volatile organic compounds (OVOC) contain $\mathrm{C}, \mathrm{H}$, and $\mathrm{O}$; examples include alcohols, aldehydes, ketones, and organic acids. NMHC and OVOC together account for nearly all the gas-phase non-methane organic compounds (NMOC) emitted by fires. The distinction is important when discussing the role of NMOCs in postemission chemistry. All of the organic compounds are impor- tant in secondary processes such as ozone and aerosol formation, but the OVOC are more abundant (60-80\% of NMOC on a molar basis, Yokelson et al., 2008), and the OVOC and NMHC tend to have different atmospheric chemistry (Singh et al., 1995; Finlayson-Pitts and Pitts, 2000). It is also important to note that only on the order of 50\% (by mass) of the observed gas-phase NMOC can be assigned to specific compounds (Christian et al., 2003; Karl et al., 2007). The remaining unidentified species are mostly high molecular weight NMOC. The unidentified species evidently play a large role in plume chemistry (Sect. 3.4, Trentmann et al., 2005; Alvarado and Prinn, 2009). We discuss NMOC in detail and estimate total global NMOC considering the large percentage of compounds that remain unidentified in Sect. 3.4.

\subsubsection{Common terminology used in computing regional/global emission estimates}

We briefly define common terms used in quantifying biomass for emission estimates. Biomass is described as primarily live (phytomass) or dead (necromass) plant material and can be discussed as total aboveground biomass (TAGB) referring to the litter layer and everything above - or total belowground biomass (TBGB), referring to duff, peat, organic soils, and roots (Seiler and Crutzen, 1980). Both terms are normally expressed on a dry weight basis. Fuel moisture can be calculated as (wet weight-dry weight)/dry weight, and along with fuel geometry affects what biomass is likely to burn. The term "fuel" in the forestry literature refers to only that portion of the total available biomass that normally burns under specified fire conditions (Neary et al., 2005). Thus, "fuel" and "biomass" are not equivalent terms in forestry, although they are sometimes used interchangeably by atmospheric chemists. Both fuel and biomass loading are typically expressed as the mass of fuel or biomass per unit area on a dry weight basis. A combustion factor is the fraction of biomass exposed to a fire that was actually consumed or volatilized. The biomass loading is often multiplied by a combustion factor to derive an estimate of how much biomass was consumed, otherwise known as the biomass consumption (per unit area). An estimate of the total combusted biomass can be obtained given biomass consumption per unit area and an estimate of the area burned. Measurements of biomass consumption per unit area burned have been published and we compile these values for several main fire types (e.g. savanna, boreal and tropical forest) in Sect. 2.4.

\subsubsection{Sampling considerations and study selection criteria for this compilation}

Smoke contains numerous species with atmospheric lifetimes ranging from micro-seconds to years. Other than a few continuously regenerated intermediates, current technology can only measure atmospheric species that are abundant and 
stable enough to have lifetimes of a few minutes or longer. In practice this means that measurements show the effects of aging for some detected species unless samples are taken within 10s of meters above lab fires or within $1-2 \mathrm{~km}$ of fires in the field. Under these conditions, smoke typically has $\mathrm{CO}$ concentrations in the range $5-1500 \mathrm{ppmv}$ in the lab or on the ground, and 2-30 ppmv in airborne studies. Figure 3 in Christian et al. (2003) or Figs. 2-4 in Yokelson et al. (2008) show that field samples meeting the above "freshness criteria" can often return similar emission factors for trace gases when compared to lab studies at the same MCE. Laboratory fires sometimes tend to burn with a different average MCE than fires in similar fuels burning in the natural environment, but this can be accounted for as described in Yokelson et al. (2008).

For particles and semi-volatile organic compounds (SVOC) the picture is less clear. Particulate matter (PM, solid or liquid particles suspended in air) is directly emitted from fires, but can also be formed through secondary processes that may involve SVOC. The lab EF(PM) vs. MCE can be quite consistent with low-level airborne measurements of EF(PM) vs. MCE (e.g., Fig. 5 of Yokelson et al., 2008). On the other hand, Babbitt et al. (1996) compared $\mathrm{EF}\left(\mathrm{PM}_{2.5}\right)$ (particles with aerodynamic diameter $<2.5$ microns) measured from $30 \mathrm{~m}$ towers above Brazilian fires to $\mathrm{EF}\left(\mathrm{PM}_{2.5}\right)$ measured using identical gravimetric methods from an aircraft flying over the same fires. Except for the lowest MCE fire (perhaps the coolest smoke) the ground-based $\mathrm{EF}\left(\mathrm{PM}_{2.5}\right)$ were only about one-half those measured from the air, while the agreement for volatile trace gases vs. MCE from both platforms was excellent. In order to prevent highly sensitive particle instruments from saturating, some lab BB studies employ rapid dilution with room temperature air. This could possibly differ from the dilution/cooling regime associated with injection of emissions into the atmosphere during some real fires. Thus, for now, we favored the data from low-level airborne smoke samples (taken after any rapid initial cooling, but before most of the photochemistry) to derive our "initial emissions" of particles (and SVOC if available). Our compilation does include lab-measured EF for two scenarios: (1) when the fuel burns entirely by smoldering combustion in the natural environment (e.g. peat, duff), and (2) when the fuel burns by both flaming and smoldering, but the authors took special care to realistically replicate the natural fuel complex and they report data for compounds not yet measured in the field. For example, the lab study of Goode et al. (1999) was the first to use FTIR on grass fires, but none of the results are included because they are superseded by the FTIR-based field study of savanna fires by Yokelson et al. (2003). On the other hand, we include the lab study of Christian et al. (2003), which carefully replicated savanna fires and also features the only proton-transfer mass spectrometer (PTR-MS) measurements of the emissions from this fire type. Finally, we point out that a lot of important work has characterized particle emissions from lab fires recently (e.g. Chen et al., 2006; Engling et al., 2006; Hopkins et al., 2007; Mazzoleni et al., 2007; Chakrabarty et al., 2010), but did not report the results as EF. Thus, it was not always clear how to incorporate these results into initial particle characteristics for models that would be analogous to the trace gas and particle EF we report.

Another important consideration for field studies is that smoldering combustion can produce unlofted smoke with low MCE that is not amenable to airborne sampling. Groundbased sampling can measure these sometimes substantial emissions, but realistic estimates of the biomass consumption contributing to the two different types of smoke are needed to properly weight the ground-based and airborne measurements (Christian et al., 2007).

In order to present a compilation that is as up to date as possible, we include some EF values from papers under review and a few preliminary EF values that are believed to be "final" from papers on the verge of submission. These values are clearly indicated in the Supplement Tables and the reader using these values should locate the forthcoming publications, check for updates, and cite those publications directly. In general we encourage the reader to examine and cite the original work that we compile and also consider modifying our averaging schemes to better suit their specific needs.

\subsection{Fire-type categories}

\subsubsection{Vegetation}

We organize the selected EF for landscape-scale fires into six broad types of vegetation susceptible to burning: savanna, tropical forest, boreal forest, temperate forest, peatlands, and chaparral. We split the category "extratropical forest" used by Andreae and Merlet (2001) into "boreal" (high latitude $\sim 50-70^{\circ}$ forested regions) and "temperate" forest. We also derive EF for "extratropical" forest fires using a weighted average of boreal and temperate emission factors ( $86.5 \%$ and $13.5 \%$, respectively) based on GFED3 biomass consumption estimates (van der Werf et al., 2010) to preserve the option of using this category. We present a specific category for chaparral (a type of temperate shrubland) since the emissions from chaparral fires are important in the southwestern US and shrublands are widespread globally (Friedl et al., 2002). (Some of the temperate forest and chaparral EF we include are flagged as preliminary in the Supplement Tables.) Our category "tropical forest" includes tropical evergreen forest deforestation fires, tropical dry forest deforestation fires, and tropical dry forest understory fires. Tropical dry forest is also called "seasonal" or "monsoon" forest. Tropical dry forests (TDF) differ from "woody" savanna regions in that TDF are characterized by a significant ( $>60 \%$ ) canopy coverage or closed canopies (Mooney et al., 1995; Friedl et al., 2002). Savanna regions are qualitatively described as grassland with an "open" canopy of trees (if any). Our savanna category includes the savanna, woody savanna, and grassland categories 
in the detailed MODIS land cover products (Friedl et al., 2002). Our savanna and tropical forest categories contribute the most open burning emissions globally (Andreae and Merlet, 2001). While peatlands represent $3 \%$ of terrestrial cover, they hold about one third of the world's soil carbon (Rein et al., 2009; Yu et al., 2010) and can be a significant contributor to annual carbon emissions (Page et al., 2002).

\subsubsection{Biofuel}

We use "biofuel" as a specific term denoting biomass used as a domestic or industrial energy source. In assessing the impacts of biofuel it is worth recalling that, in principle, it could be regrown so is potentially "renewable" unlike fossil fuel. Rural populations in developing countries rely heavily on biomass burning as a primary source of energy (Smil, 1979; Cecelski et al., 1979; Yevich and Logan, 2003). The amount of biofuel use in urban areas of the developing world is not known, but may be significant (Christian et al., 2010). Over the 50-yr period from 1950-2000, Fernandes et al. (2007) estimated a $70 \%$ growth in global annual biofuel consumption making it now the second largest type of global biomass burning after savanna fires (Andreae and Merlet, 2001), but future trends are hard to predict. In this work we present biofuel emission factors for open cooking fires, dung burning, Patsari cooking stoves, charcoal making, and charcoal burning. Open cooking fires are the single largest contributor to global biofuel emissions accounting for roughly $80 \%$ of current biofuel use worldwide (Dherani et al., 2008). Various stove designs are available, but the most complete emissions measurements have been made for Patsari stoves; therefore, we selected them to represent emissions from all types of biofuel stoves. Patsari stoves are used in Mexico and incorporate an insulated fire box that vents emissions outdoors via a metal chimney (Christian et al., 2010). The stoves are designed to replace traditional open three-stone fires and can reduce indoor air pollution by $70 \%$. Stoves in general require less fuel per cooking task than open cooking fires, which reduces emissions and pressure on biofuel sources (Johnson et al., 2008; Masera et al., 2005; Zuk et al., 2007). For the above reasons there is considerable international activity to encourage switching from open cooking fires to stoves. In addition, the Patsari stove emissions were found to have different chemistry than open cooking fire emissions (Johnson et al., 2008; Christian et al., 2010), further justifying a separate category in this study. While not fully representative of all cooking stoves, the Patsari stove EF likely represent most stove emissions better than EF for open cooking fires and might be used to help assess the impact of changes in how biofuel is used.

Dung as a biofuel is mainly of note in Asia, dominated by use in India and China (Yevich and Logan, 2003). Its use in most other rural areas globally is less common than that of woodfuel (though sometimes still significant), and overall it comprises approximately $5 \%$ of the total dry matter burned as biofuel (Yevich and Logan, 2003). Charcoal is mainly produced in rural areas and often consumed in urban areas, accounting for $\sim 10 \%$ of global biofuel use (Bertschi et al., 2003a).

\subsubsection{Agricultural/waste burning}

Crop residue and pasture maintenance fires and open burning of garbage can be common both in rural agricultural regions and peri-urban areas. For instance, sugarcane burning is the main source of PM in some Brazilian cities (Lara et al., 2005; Cançado et al., 2006). Crop residue burning has been estimated as the fourth largest type of biomass burning (Andreae and Merlet, 2001), but these emissions could be greatly underestimated given the difficulty of detecting these often short-lived, relatively small fires from space (Hawbaker et al., 2008; Smith et al., 2007; Chang and Song, 2010a; van der Werf et al., 2010). Crop residue may be burned 1-3 times a year on a single site depending on the rate of annual harvest. Some crop residue is utilized as biofuel (especially in China), blurring the distinction between these categories (Yevich and Logan, 2003). A recent increase in crop residue burning is likely in large areas of the Amazon concurrent with a shift in land use from cattle ranching to crop production (Cardille and Foley, 2003; Morton et al., 2006). Pasture maintenance burning is performed every $2-3 \mathrm{yr}$ to prevent reconversion of pasture to forest. These fires frequently include residual smoldering combustion of large logs that can burn for weeks after the flames have ceased (Kauffman et al., 1998). Garbage burning is normally overlooked as an emissions source. However, Christian et al. (2010) estimate that $\sim 2000 \mathrm{Tg} \mathrm{yr}^{-1}$ of garbage are generated globally and roughly half may be burned in open fires or incinerators. Partly because open garbage burning is often illegal, it is unmentioned in most inventories. We compile the few available EF for open burning of garbage as a separate category.

\subsection{Assessment, calculation, and application of emission factors for specific fire types}

This section provides the details of how we analyzed the emission factors. We classify biomass burning into 14 categories. For each of these categories, we organize the information by study in Supplement Tables S1-S14 for all studies meeting our selection criteria (updates at: http://bai.acd. ucar.edu/Data/fire/). For each included study we show the study-average emission factors and any additional specifics considered in calculating an overall average and estimate of the natural variation for the whole category. The rationale supporting the calculation of the category average and variation is summarized in the following sections. We present just the category average emission factors and category variability for all 14 BB categories in Tables 1 and 2. Our classification scheme allows consideration/assessment of fairly specific emission types while retaining the option of merging 
Table 1. Emission factors $\left(\mathrm{g} \mathrm{kg}^{-1}\right)$ for species emitted from different types of biomass burning $\mathrm{a}^{\mathrm{a}}$.

\begin{tabular}{|c|c|c|c|c|c|c|c|}
\hline & Tropical Forest & Savanna & $\begin{array}{l}\text { Crop } \\
\text { Residue }\end{array}$ & $\begin{array}{l}\text { Pasture } \\
\text { Maintenance }\end{array}$ & $\begin{array}{l}\text { Boreal } \\
\text { Forest }\end{array}$ & $\begin{array}{l}\text { Temperate } \\
\text { Forest }\end{array}$ & $\begin{array}{l}\text { Extratropical } \\
\text { Forest }^{b}\end{array}$ \\
\hline Carbon Dioxide $\left(\mathrm{CO}_{2}\right)$ & $1643(58)$ & $1686(38)$ & $1585(100)$ & $1548(142)$ & $1489(121)$ & $1637(71)$ & $1509(98)$ \\
\hline Carbon Monoxide (CO) & $93(27)$ & $63(17)$ & $102(33)$ & $135(38)$ & $127(45)$ & $89(32)$ & $122(44)$ \\
\hline Methane $\left(\mathrm{CH}_{4}\right)$ & $5.07(1.98)$ & $1.94(0.85)$ & $5.82(3.56)$ & $8.71(4.97)$ & $5.96(3.14)$ & $3.92(2.39)$ & $5.68(3.24)$ \\
\hline Acetylene $\left(\mathrm{C}_{2} \mathrm{H}_{2}\right)$ & $0.44(0.35)$ & $0.24(0.10)$ & $0.27(0.08)$ & $0.21(0.29)$ & $0.18(0.10)$ & $0.29(0.10)$ & $0.19(0.090)$ \\
\hline Ethylene $\left(\mathrm{C}_{2} \mathrm{H}_{4}\right)$ & $1.06(0.37)$ & $0.82(0.35)$ & $1.46(0.59)$ & $1.28(0.71)$ & $1.42(0.43)$ & $1.12(0.35)$ & $1.38(0.42)$ \\
\hline Ethane $\left(\mathrm{C}_{2} \mathrm{H}_{6}\right)$ & $0.71(0.28)$ & $0.66(0.41)$ & $0.91(0.49)$ & $0.95(0.43)$ & $1.79(1.14)$ & $1.12(0.67)$ & $1.70(1.05)$ \\
\hline Propadiene $\left(\mathrm{C}_{3} \mathrm{H}_{4}\right)$ & $0.016(0.0066)$ & $0.012(0.005)$ & - & $0.020(0.009)$ & - & - & - \\
\hline Propylene $\left(\mathrm{C}_{3} \mathrm{H}_{6}\right)$ & $0.64(0.43)$ & $0.79(0.56)$ & $0.68(0.37)$ & $0.85(0.66)$ & $1.13(0.60)$ & $0.95(0.54)$ & $1.11(0.61)$ \\
\hline Propyne $\left(\mathrm{C}_{3} \mathrm{H}_{4}\right)$ & - & - & - & - & 0.059 & - & 0.059 \\
\hline Propane $\left(\mathrm{C}_{3} \mathrm{H}_{8}\right)$ & $0.126(0.060)$ & $0.10(0.067)$ & $0.28(0.15)$ & $0.22(0.10)$ & 0.44 & $0.26(0.11)$ & $0.42(0.18)$ \\
\hline$n$-Butane $\left(\mathrm{C}_{4} \mathrm{H}_{10}\right)$ & $0.038(0.023)$ & $0.016(0.013)$ & $0.072(0.036)$ & $0.040(0.018)$ & 0.12 & $0.083(0.10)$ & $0.12(0.14)$ \\
\hline$i$-Butane $\left(\mathrm{C}_{4} \mathrm{H}_{10}\right)$ & $0.011(0.009)$ & $0.0043(0.0027)$ & $0.025(0.013)$ & $0.014(0.0063)$ & 0.042 & - & 0.042 \\
\hline 1-Butene $\left(\mathrm{C}_{4} \mathrm{H}_{8}\right)$ & $0.079(0.024)$ & $0.043(0.022)$ & $0.134(0.060)$ & $0.17(0.077)$ & 0.16 & - & 0.16 \\
\hline$i$-Butene $\left(\mathrm{C}_{4} \mathrm{H}_{8}\right)$ & $0.11(0.051)$ & $0.024(0.0051)$ & $0.117(0.060)$ & $0.11(0.05)$ & 0.11 & - & 0.11 \\
\hline 1,3-Butadiene $\left(\mathrm{C}_{4} \mathrm{H}_{6}\right)$ & 0.039 & $0.052(0.028)$ & $0.151(0.072)$ & - & 0.14 & - & 0.14 \\
\hline trans-2-Butene $\left(\mathrm{C}_{4} \mathrm{H}_{8}\right)$ & $0.029(0.013)$ & $0.011(0.0055)$ & $0.057(0.030)$ & $0.050(0.023)$ & 0.040 & - & 0.040 \\
\hline cis-2-Butene $\left(\mathrm{C}_{4} \mathrm{H}_{8}\right)$ & $0.024(0.010)$ & $0.0084(0.0043)$ & $0.043(0.023)$ & $0.040(0.018)$ & 0.030 & - & 0.030 \\
\hline$n$-Pentane $\left(\mathrm{C}_{5} \mathrm{H}_{12}\right)$ & $8.03 \times 10^{-3}\left(8.03 \times 10^{-3}\right)$ & $0.0032(0.0032)$ & $0.025(0.012)$ & $0.0056(0.0025)$ & 0.085 & - & 0.085 \\
\hline$i$-Pentane $\left(\mathrm{C}_{5} \mathrm{H}_{12}\right)$ & $0.010(0.010)$ & $0.0022(0.0032)$ & $0.020(0.012)$ & $0.0074(0.0033)$ & 0.038 & - & 0.038 \\
\hline trans-2-Pentene $\left(\mathrm{C}_{5} \mathrm{H}_{10}\right)$ & $3.30 \times 10^{-3}$ & $0.0045(0.0028)$ & - & - & - & - & - \\
\hline cis-2-Pentene $\left(\mathrm{C}_{5} \mathrm{H}_{10}\right)$ & $1.90 \times 10^{-3}$ & $0.0025(0.0018)$ & - & - & - & - & - \\
\hline 3-Methyl-1-Butene $\left(\mathrm{C}_{5} \mathrm{H}_{10}\right)$ & $3.80 \times 10^{-3}$ & $0.0051(0.0034)$ & - & - & - & - & - \\
\hline 2-Methyl-2-Butene $\left(\mathrm{C}_{5} \mathrm{H}_{10}\right)$ & $4.00 \times 10^{-3}$ & $0.0048(0.0035)$ & - & - & - & - & - \\
\hline 2-Methyl-1-Butene $\left(\mathrm{C}_{5} \mathrm{H}_{10}\right)$ & $4.40 \times 10^{-3}$ & $0.0059(0.0037)$ & - & - & - & - & - \\
\hline Isoprene $\left(\mathrm{C}_{5} \mathrm{H}_{8}\right)$ & $0.13(0.056)$ & $0.039(0.027)$ & $0.38(0.16)$ & $0.12(0.055)$ & 0.15 & - & 0.15 \\
\hline Cyclopentane $\left(\mathrm{C}_{5} \mathrm{H}_{10}\right)$ & - & - & $0.0019(0.0012)$ & - & - & - & - \\
\hline 2+3-Methylpentane $\left(\mathrm{C}_{6} \mathrm{H}_{14}\right)$ & - & - & - & - & 0.036 & - & 0.036 \\
\hline 2-Methyl-1-Pentene $\left(\mathrm{C}_{6} \mathrm{H}_{12}\right)$ & $2.80 \times 10^{-3}$ & $0.0035(0.0021)$ & - & - & - & - & - \\
\hline$n$-Hexane $\left(\mathrm{C}_{6} \mathrm{H}_{14}\right)$ & 0.010 & $0.013(0.0074)$ & - & - & 0.055 & - & 0.055 \\
\hline Heptane $\left(\mathrm{C}_{7} \mathrm{H}_{16}\right)$ & $5.60 \times 10^{-3}$ & $0.0070(0.0072)$ & - & - & 0.048 & - & 0.048 \\
\hline Benzene $\left(\mathrm{C}_{6} \mathrm{H}_{6}\right)$ & $0.39(0.16)$ & $0.20(0.084)$ & $0.15(0.04)$ & $0.70(0.32)$ & 1.11 & - & 1.11 \\
\hline Toluene $\left(\mathrm{C}_{6} \mathrm{H}_{5} \mathrm{CH}_{3}\right)$ & $0.26(0.13)$ & $0.080(0.058)$ & $0.19(0.06)$ & $0.34(0.15)$ & 0.48 & - & 0.48 \\
\hline Xylenes $\left(\mathrm{C}_{8} \mathrm{H}_{10}\right)$ & $0.11(0.082)$ & $0.014(0.024)$ & - & $0.11(0.050)$ & 0.18 & - & 0.18 \\
\hline Ethylbenzene $\left(\mathrm{C}_{8} \mathrm{H}_{10}\right)$ & $0.050(0.036)$ & $0.006(0.010)$ & - & $0.067(0.030)$ & 0.051 & - & 0.051 \\
\hline$n$-Propylbenzene $\left(\mathrm{C}_{9} \mathrm{H}_{12}\right)$ & - & - & - & - & 0.018 & - & 0.018 \\
\hline$\alpha$-Pinene $\left(\mathrm{C}_{10} \mathrm{H}_{16}\right)$ & - & - & - & - & 1.64 & - & 1.64 \\
\hline$\beta$-Pinene $\left(\mathrm{C}_{10} \mathrm{H}_{16}\right)$ & - & - & - & - & 1.45 & - & 1.45 \\
\hline Ethanol $\left(\mathrm{CH}_{3} \mathrm{CH}_{2} \mathrm{OH}\right)$ & - & - & - & - & 0.055 & - & 0.055 \\
\hline Methanol $\left(\mathrm{CH}_{3} \mathrm{OH}\right)$ & $2.43(0.80)$ & $1.18(0.41)$ & $3.29(1.38)$ & $5.84(3.42)$ & $2.82(1.62)$ & $1.93(1.38)$ & $2.70(1.75)$ \\
\hline Phenol $\left(\mathrm{C}_{6} \mathrm{H}_{5} \mathrm{OH}\right)$ & $0.45(0.088)$ & $0.52(0.36)$ & $0.52(0.14)$ & $1.68(3.34)$ & 2.96 & $0.33(0.38)$ & $2.60(3.00)$ \\
\hline Formaldehyde (HCHO) & $1.73(1.22)$ & $0.73(0.62)$ & $2.08(0.84)$ & $1.90(1.11)$ & $1.86(1.26)$ & $2.27(1.13)$ & $1.92(1.14)$ \\
\hline Glycolaldehyde $\left(\mathrm{C}_{2} \mathrm{H}_{4} \mathrm{O}_{2}\right)$ & 2.84 & $0.81(0.38)$ & $2.01(0.38)$ & - & 0.77 & $0.25(0.45)$ & $0.70(1.26)$ \\
\hline Acetaldehyde $\left(\mathrm{CH}_{3} \mathrm{CHO}\right)$ & $1.55(0.75)$ & $0.57(0.30)$ & $1.24(0.28)$ & $2.40(1.08)$ & - & - & - \\
\hline Acrolein $\left(\mathrm{C}_{3} \mathrm{H}_{4} \mathrm{O}\right)$ & $0.65(0.23)$ & - & - & - & - & - & - \\
\hline Furaldehydes & $0.29(0.0010)$ & - & - & - & - & - & - \\
\hline Propanal $\left(\mathrm{C}_{3} \mathrm{H}_{6} \mathrm{O}\right)$ & $0.10(0.026)$ & - & - & $0.16(0.074)$ & - & - & - \\
\hline Methyl Propanal $\left(\mathrm{C}_{4} \mathrm{H}_{8} \mathrm{O}\right)$ & $0.18(0.075)$ & - & - & $0.33(0.15)$ & - & - & - \\
\hline Hexanal $\left(\mathrm{C}_{6} \mathrm{H}_{12} \mathrm{O}\right)$ & $0.01(0.005)$ & - & - & $0.034(0.015)$ & - & - & - \\
\hline Acetone $\left(\mathrm{C}_{3} \mathrm{H}_{6} \mathrm{O}\right)$ & $0.63(0.17)$ & $0.16(0.13)$ & $0.45(0.07)$ & $1.05(0.47)$ & 0.75 & - & 0.75 \\
\hline Methyl Vinyl Ether $\left(\mathrm{C}_{3} \mathrm{H}_{6} \mathrm{O}\right)$ & - & $0.16(0.045)$ & $0.08(0.01)$ & - & - & - & - \\
\hline Methacrolein $\left(\mathrm{C}_{4} \mathrm{H}_{6} \mathrm{O}\right)$ & $0.15(0.045)$ & - & - & $0.40(0.18)$ & 0.087 & - & 0.087 \\
\hline Crotonaldehyde $\left(\mathrm{C}_{4} \mathrm{H}_{6} \mathrm{O}\right)$ & $0.24(0.068)$ & - & - & $0.60(0.27)$ & - & - & - \\
\hline 2,3-Butanedione $\left(\mathrm{C}_{4} \mathrm{H}_{6} \mathrm{O}_{2}\right)$ & $0.73(0.22)$ & - & - & $1.58(0.71)$ & - & - & - \\
\hline Methyl Vinyl Ketone $\left(\mathrm{C}_{4} \mathrm{H}_{6} \mathrm{O}\right)$ & $0.39(0.11)$ & - & - & $1.00(0.45)$ & 0.20 & - & 0.20 \\
\hline Methyl Ethyl Ketone $\left(\mathrm{C}_{4} \mathrm{H}_{8} \mathrm{O}\right)$ & $0.50(0.21)$ & - & - & $0.94(0.42)$ & 0.22 & - & 0.22 \\
\hline 2-Pentanone $\left(\mathrm{C}_{5} \mathrm{H}_{10} \mathrm{O}\right)$ & $0.08(0.024)$ & - & - & $0.17(0.077)$ & - & - & - \\
\hline 3-Pentanone $\left(\mathrm{C}_{5} \mathrm{H}_{10} \mathrm{O}\right)$ & $0.03(0.011)$ & - & - & $0.08(0.034)$ & - & - & - \\
\hline Furan $\left(\mathrm{C}_{4} \mathrm{H}_{4} \mathrm{O}\right)$ & $0.41(0.10)$ & $0.17(0.058)$ & $0.11(0.04)$ & $1.02(0.43)$ & $0.80(0.50)$ & $0.20(0.21)$ & $0.72(0.62)$ \\
\hline 3-Methylfuran $\left(\mathrm{C}_{5} \mathrm{H}_{6} \mathrm{O}\right)$ & $0.59(0.20)$ & - & - & $1.41(0.64)$ & - & - & - \\
\hline 2-Methylfuran $\left(\mathrm{C}_{5} \mathrm{H}_{6} \mathrm{O}\right)$ & $0.08(0.028)$ & - & - & $0.20(0.091)$ & - & - & - \\
\hline Other substituted furans & $1.21(0.016)$ & - & - & - & - & - & - \\
\hline $\mathrm{C}_{6}$ Carbonyls & $0.24(0.11)$ & - & - & $0.61(0.28)$ & - & - & - \\
\hline Acetol $\left(\mathrm{C}_{3} \mathrm{H}_{6} \mathrm{O}_{2}\right)$ & $1.13(0.12)$ & $0.45(0.24)$ & $3.77(0.91)$ & $6.18(5.60)$ & - & - & - \\
\hline Acetonitrile $\left(\mathrm{CH}_{3} \mathrm{CN}\right)$ & $0.41(0.10)$ & $0.11(0.058)$ & $0.21(0.06)$ & $0.55(0.25)$ & 0.61 & - & 0.61 \\
\hline Propenenitrile $\left(\mathrm{C}_{3} \mathrm{H}_{3} \mathrm{~N}\right)$ & $0.04(0.01)$ & $0.051(0.022)$ & $0.03(0.002)$ & - & - & - & - \\
\hline Propanenitrile $\left(\mathrm{C}_{3} \mathrm{H}_{5} \mathrm{~N}\right)$ & 0.090 & $0.031(0.014)$ & $0.06(0.002)$ & - & - & - & - \\
\hline
\end{tabular}


Table 1. Continued.

\begin{tabular}{|c|c|c|c|c|c|c|c|}
\hline & Tropical Forest & Savanna & $\begin{array}{l}\text { Crop } \\
\text { Residue }\end{array}$ & $\begin{array}{l}\text { Pasture } \\
\text { Maintenance }\end{array}$ & $\begin{array}{l}\text { Boreal } \\
\text { Forest }\end{array}$ & $\begin{array}{l}\text { Temperate } \\
\text { Forest }\end{array}$ & $\begin{array}{l}\text { Extratropical } \\
\text { Forest }^{\mathrm{b}}\end{array}$ \\
\hline Pyrrole $\left(\mathrm{C}_{4} \mathrm{H}_{5} \mathrm{~N}\right)$ & $0.12(0.038)$ & - & - & - & - & - & - \\
\hline Formic Acid (HCOOH) & $0.79(0.66)$ & $0.21(0.096)$ & $1.00(0.49)$ & $0.20(0.64)$ & $0.57(0.46)$ & $0.35(0.33)$ & $0.54(0.47)$ \\
\hline Acetic Acid $\left(\mathrm{CH}_{3} \mathrm{COOH}\right)$ & $3.05(0.90)$ & $3.55(1.47)$ & $5.59(2.55)$ & $10.4(6.8)$ & $4.41(2.66)$ & $1.97(1.66)$ & $4.08(2.99)$ \\
\hline Hydrogen Cyanide ( $\mathrm{HCN})$ & $0.42(0.26)$ & $0.41(0.15)$ & $0.29(0.38)$ & $0.46(0.45)$ & $1.52(0.82)$ & $0.73(0.19)$ & $1.41(0.60)$ \\
\hline Dimethyl Sulfide $\left(\mathrm{C}_{2} \mathrm{H}_{6} \mathrm{~S}\right)$ & $1.35 \times 10^{-3}\left(1.71 \times 10^{-3}\right)$ & $0.0013(0.0011)$ & - & - & $4.65 \times 10^{-3}$ & - & $4.65 \times 10^{-3}$ \\
\hline Carbonyl Sulfide (OCS) & 0.025 & - & - & - & $0.46(0.47)$ & - & $0.46(0.47)$ \\
\hline Chloromethane $\left(\mathrm{CH}_{3} \mathrm{Cl}\right)$ & $0.053(0.038)$ & $0.055(0.036)$ & - & $0.29(0.13)$ & 0.059 & - & 0.059 \\
\hline Dibromomethane $\left(\mathrm{CH}_{2} \mathrm{Br}_{2}\right)$ & - & - & - & - & $8.28 \times 10^{-5}$ & - & $8.28 \times 10^{-5}$ \\
\hline 1,2-Dichloroethane $\left(\mathrm{C}_{2} \mathrm{H}_{4} \mathrm{Cl}_{2}\right)$ & - & - & - & - & $1.29 \times 10^{-3}$ & - & $1.29 \times 10^{-3}$ \\
\hline Methyl Bromide $\left(\mathrm{CH}_{3} \mathrm{Br}\right)$ & $2.83 \times 10^{-3}\left(2.38 \times 10^{-3}\right)$ & $8.53 \times 10^{-4}\left(8.62 \times 10^{-4}\right)$ & - & $5.71 \times 10^{-3}\left(2.57 \times 10^{-3}\right)$ & $3.64 \times 10^{-3}$ & - & $3.64 \times 10^{-3}$ \\
\hline Methyl Iodide $\left(\mathrm{CH}_{3} \mathrm{I}\right)$ & $2.50 \times 10^{-3}\left(3.45 \times 10^{-3}\right)$ & $5.06 \times 10^{-4}\left(3.88 \times 10^{-4}\right)$ & - & $3.48 \times 10^{-3}\left(1.56 \times 10^{-3}\right)$ & $7.88 \times 10^{-4}$ & - & $7.88 \times 10^{-4}$ \\
\hline Trichloromethane $\left(\mathrm{CHCl}_{3}\right)$ & $2.94 \times 10^{-4}\left(6.75 \times 10^{-3}\right)$ & $0.012(0.020)$ & - & $6.32 \times 10^{-4}\left(2.84 \times 10^{-4}\right)$ & - & - & - \\
\hline Dichlorodifluoromethane $\left(\mathrm{CCl}_{2} \mathrm{~F}_{2}\right)$ & $2.80 \times 10^{-3}$ & - & - & - & - & - & - \\
\hline Ethylchloride $\left(\mathrm{C}_{2} \mathrm{H}_{5} \mathrm{Cl}\right)$ & - & - & - & - & $7.47 \times 10^{-4}$ & - & $7.47 \times 10^{-4}$ \\
\hline Ammonia $\left(\mathrm{NH}_{3}\right)$ & $1.33(1.21)$ & $0.52(0.35)$ & $2.17(1.27)$ & $1.47(1.29)$ & $2.72(2.32)$ & $0.78(0.82)$ & $2.46(2.35)$ \\
\hline Methyl Nitrate $\left(\mathrm{CH}_{3} \mathrm{ONO}_{2}\right)$ & $8.29 \times 10^{-3}\left(1.60 \times 10^{-2}\right)$ & $5.1 \times 10^{-4}\left(3.7 \times 10^{-4}\right)$ & - & - & $2.83 \times 10^{-3}$ & - & $2.83 \times 10^{-3}$ \\
\hline Ethyl Nitrate $\left(\mathrm{C}_{2} \mathrm{H}_{5} \mathrm{NO}_{3}\right)$ & $5.70 \times 10^{-3}$ & - & - & - & $1.78 \times 10^{-3}$ & - & $1.78 \times 10^{-3}$ \\
\hline$n$-Propyl Nitrate $\left(\mathrm{C}_{3} \mathrm{H}_{7} \mathrm{NO}_{3}\right)$ & 0.0003 & - & - & - & $3.23 \times 10^{-4}$ & - & $3.23 \times 10^{-4}$ \\
\hline$i$-Propyl Nitrate $\left(\mathrm{C}_{3} \mathrm{H}_{7} \mathrm{NO}_{3}\right)$ & 0.001 & - & - & - & $3.23 \times 10^{-3}$ & - & $3.23 \times 10^{-3}$ \\
\hline 2-Butyl Nitrate $\left(\mathrm{C}_{4} \mathrm{H}_{9} \mathrm{NO}_{3}\right)$ & 0.0006 & - & - & - & $3.84 \times 10^{-3}$ & - & $3.84 \times 10^{-3}$ \\
\hline 3-Pentyl Nitrate $\left(\mathrm{C}_{5} \mathrm{H}_{11} \mathrm{NO}_{3}\right)$ & - & - & - & - & $7.27 \times 10^{-4}$ & - & $7.27 \times 10^{-4}$ \\
\hline 2-Pentyl Nitrate $\left(\mathrm{C}_{5} \mathrm{H}_{11} \mathrm{NO}_{3}\right)$ & - & - & - & - & $9.70 \times 10^{-4}$ & - & $9.70 \times 10^{-4}$ \\
\hline 3-Methyl-2-Butyl Nitrate $\left(\mathrm{C}_{5} \mathrm{H}_{11} \mathrm{NO}_{3}\right)$ & - & - & - & - & $1.15 \times 10^{-3}$ & - & $1.15 \times 10^{-3}$ \\
\hline 3 -Ethyltoluene $\left(\mathrm{C}_{9} \mathrm{H}_{12}\right)$ & - & - & - & - & 0.024 & - & 0.024 \\
\hline 2-Ethyltoluene $\left(\mathrm{C}_{9} \mathrm{H}_{12}\right)$ & - & - & - & - & 0.011 & - & 0.011 \\
\hline 4-Ethyltoluene $\left(\mathrm{C}_{9} \mathrm{H}_{12}\right)$ & - & - & - & - & 0.015 & - & 0.015 \\
\hline 1,2,3-Trimethylbenzene $\left(\mathrm{C}_{9} \mathrm{H}_{12}\right)$ & - & - & - & - & 0.051 & - & 0.051 \\
\hline 1,2,4-Trimethylbenzene $\left(\mathrm{C}_{9} \mathrm{H}_{12}\right)$ & - & - & - & - & 0.030 & - & 0.030 \\
\hline 1,3,5-Trimethylbenzene $\left(\mathrm{C}_{9} \mathrm{H}_{12}\right)$ & - & - & - & - & $5.86 \times 10^{-3}$ & - & $5.86 \times 10^{-3}$ \\
\hline Hydrogen $\left(\mathrm{H}_{2}\right)$ & $3.36(1.30)$ & $1.70(0.64)$ & $2.59(1.78)$ & - & - & $2.03(1.79)$ & $2.03(1.79)$ \\
\hline Sulfur Dioxide $\left(\mathrm{SO}_{2}\right)$ & $0.40(0.19)$ & $0.48(0.27)$ & - & $0.32(0.14)$ & - & - & - \\
\hline Nitrous Acid (HONO) & 1.18 & 0.20 & - & $0.16(0.07)$ & - & $0.52(0.15)$ & $0.52(0.15)$ \\
\hline Nitrogen Oxides $\left(\mathrm{NO}_{\mathrm{x}}\right.$ as $\left.\mathrm{NO}\right)$ & $2.55(1.40)$ & $3.9(0.80)$ & $3.11(1.57)$ & $0.75(0.59)$ & $0.90(0.69)$ & $2.51(1.02)$ & $1.12(0.69)$ \\
\hline Nitrous Oxide $\left(\mathrm{N}_{2} \mathrm{O}\right)$ & - & - & - & - & 0.41 & $0.16(0.21)$ & $0.38(0.35)$ \\
\hline NMOC (identified) & $26.0(8.8)$ & $12.4(6.2)$ & $25.7(9.8)$ & $44.8(30.1)$ & $29.3(10.1)$ & $11.9(7.6)$ & $27.0(13.8)$ \\
\hline NMOC (identified + unidentified) ${ }^{c}$ & 51.9 & 24.7 & 51.4 & 89.6 & 58.7 & 23.7 & 54.0 \\
\hline Total Particulate Carbon & $5.24(2.91)$ & $3.00(1.43)$ & - & $10.6(4.8)$ & - & - & - \\
\hline Total Suspended Particulate (TSP) & 13 & - & - & - & - & - & - \\
\hline 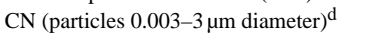 & $5.90 \times 10^{16}$ & - & - & - & - & - & - \\
\hline $\mathrm{PM}_{25}^{\mathrm{e}}$ & $9.1(3.5)$ & $7.17(3.42)$ & $6.26(2.36)$ & $14.8(6.7)$ & $15.3(5.9)$ & $12.7(7.5)$ & $15.0(7.5)$ \\
\hline $\mathrm{PM}_{10}^{2.5}$ & $18.5(4.1)$ & - & - & $28.9(13.0)$ & - & - & - \\
\hline Black Carbon (BC) & $0.52(0.28)$ & $0.37(0.20)$ & 0.75 & $0.91(0.41)$ & - & - & $0.56(0.19)^{\mathrm{f}}$ \\
\hline Organic Carbon (OC) & $4.71(2.73)$ & $2.62(1.24)$ & 2.30 & $9.64(4.34)$ & - & - & $8.6-9.7^{\mathrm{f}}$ \\
\hline Oxylate $\left(\mathrm{C}_{2} \mathrm{O}_{4}\right)$ & $0.04(0.034)$ & $0.0055(0.0055)$ & - & $0.040(0.018)$ & - & - & - \\
\hline Nitrate $\left(\mathrm{NO}_{3}\right)$ & $0.11(0.050)$ & $0.016(0.013)$ & - & $0.14(0.063)$ & - & - & - \\
\hline Phosphate $\left(\mathrm{PO}_{4}\right)$ & $5.56 \times 10^{-3}\left(8.99 \times 10^{-3}\right)$ & $0.0045(0.0060)$ & - & $1.07 \times 10^{-3}\left(4.80 \times 10^{-4}\right)$ & - & - & - \\
\hline Sulfate $\left(\mathrm{SO}_{4}\right)$ & $0.13(0.088)$ & $0.018(0.009)$ & - & $0.19(0.086)$ & - & - & - \\
\hline Ammonium $\left(\mathrm{NH}_{4}\right)$ & $5.64 \times 10^{-3}\left(1.72 \times 10^{-2}\right)$ & $0.0035(0.0035)$ & - & $3.97 \times 10^{-3}\left(1.79 \times 10^{-3}\right)$ & - & - & - \\
\hline $\mathrm{Cl}$ & $0.15(0.16)$ & $0.23(0.055)$ & - & $0.24(0.11)$ & - & - & - \\
\hline $\mathrm{Ca}$ & $0.085(0.089)$ & $0.021(0.018)$ & - & $0.020(0.009)$ & - & - & - \\
\hline $\mathrm{Mg}$ & $0.040(0.034)$ & $0.016(0.007)$ & - & $0.030(0.014)$ & - & - & - \\
\hline $\mathrm{Na}$ & $6.37 \times 10^{-3}\left(5.46 \times 10^{-3}\right)$ & $0.0055(0.0045)$ & - & $0.030(0.014)$ & - & - & - \\
\hline $\mathrm{K}$ & $0.29(0.28)$ & $0.23(0.053)$ & - & $0.34(0.15)$ & - & - & - \\
\hline
\end{tabular}

a See Sect. 2.3 for guidance in use. Emission factors are shown with an estimate of the natural variation in parenthesis, when available.

$\mathrm{b}$ EF calculated from a weighted average of boreal and temperate forest EF based on GFED3 biomass consumption estimates.

c Estimated (see Sect. 3.4).

${ }^{\mathrm{d}}$ Number of particles per $\mathrm{kg}$ of fuel burned.

e $\mathrm{PM}_{1}-\mathrm{PM}_{5}$ categorized as $\mathrm{PM}_{2.5}$.

${ }^{\mathrm{f}}$ Source is Andreae and Merlet (2001).

categories at the user's discretion. As an example, we also derive values for an "extratropical forest" category (shown in Table 1) by merging the boreal and temperate forest EF with the formula described in Sect. 2.2.1. Some users may instead desire EF in more detail than is provided by our 14 categories in Tables 1-2 and this can often be retrieved by consulting the Supplement Tables. For instance, the EF for smoldering combustion of hand-piled crop residue (common in much of Asia) are very different from the EF for flaming combustion of crop residue produced by mechanized agriculture and they can be found separately in Table S13. 
Table 2. Emission factors $\left(\mathrm{g} \mathrm{kg}^{-1}\right)$ for species emitted from different types of biomass burning ${ }^{\mathrm{a}}$.

\begin{tabular}{|c|c|c|c|c|c|c|c|c|}
\hline Compound & Peatland ${ }^{\mathrm{b}}$ & Chaparral & $\begin{array}{l}\text { Open } \\
\text { Cooking }\end{array}$ & $\begin{array}{l}\text { Patsari } \\
\text { Stoves }\end{array}$ & $\begin{array}{l}\text { Charcoal } \\
\text { Making }\end{array}$ & $\begin{array}{l}\text { Charcoal } \\
\text { Burning }^{\mathrm{d}}\end{array}$ & $\begin{array}{l}\text { Dung } \\
\text { Burning }\end{array}$ & $\begin{array}{l}\text { Garbage } \\
\text { Burning }\end{array}$ \\
\hline Carbon Dioxide $\left(\mathrm{CO}_{2}\right)$ & $1563(65)$ & $1710(39)$ & $1548(125)$ & $1610(114)$ & $1626(244)$ & 2385 & $859(15)$ & $1453(69)$ \\
\hline Carbon Monoxide (CO) & $182(60)$ & $67(13)$ & $77(26)$ & $42(19)$ & $255(52)$ & $189(36)$ & $105(10)$ & $38(19)$ \\
\hline Methane $\left(\mathrm{CH}_{4}\right)$ & $11.8(7.8)$ & $2.51(0.72)$ & $4.86(2.73)$ & $2.32(1.38)$ & $39.6(11.4)$ & $5.29(2.42)$ & $11.0(3.3)$ & $3.66(4.39)$ \\
\hline Acetylene $\left(\mathrm{C}_{2} \mathrm{H}_{2}\right)$ & $0.14(0.093)$ & $0.20(0.08)$ & $0.97(0.50)$ & $0.28(0.01)$ & $0.21(0.02)$ & 0.42 & - & $0.40(0.28)$ \\
\hline Ethylene $\left(\mathrm{C}_{2} \mathrm{H}_{4}\right)$ & $1.79(0.72)$ & $0.75(0.18)$ & $1.53(0.66)$ & $0.46(0.12)$ & $3.80(1.15)$ & $0.44(0.23)$ & $1.12(0.23)$ & $1.26(1.04)$ \\
\hline Ethane $\left(\mathrm{C}_{2} \mathrm{H}_{6}\right)$ & - & $0.36(0.11)$ & $1.50(0.50)$ & - & $12.2(9.3)$ & $0.41(0.13)$ & - & - \\
\hline Propylene $\left(\mathrm{C}_{3} \mathrm{H}_{6}\right)$ & $2.3(0.74)$ & $0.38(0.13)$ & $0.57(0.34)$ & 0.03 & $4.12(1.89)$ & - & $1.89(0.42)$ & $1.26(1.42)$ \\
\hline Propane $\left(\mathrm{C}_{3} \mathrm{H}_{8}\right)$ & - & $0.19(0.09)$ & - & - & - & - & - & - \\
\hline Butane $\left(\mathrm{C}_{4} \mathrm{H}_{10}\right)$ & - & $0.14(0.07)$ & - & - & - & - & - & - \\
\hline Isoprene $\left(\mathrm{C}_{5} \mathrm{H}_{8}\right)$ & $1.07(0.44)$ & - & - & - & - & - & - & - \\
\hline Toluene $\left(\mathrm{C}_{6} \mathrm{H}_{5} \mathrm{CH}_{3}\right)$ & $1.21(0.69)$ & - & - & - & - & - & - & - \\
\hline Benzene $\left(\mathrm{C}_{6} \mathrm{H}_{6}\right)$ & $2.46(1.21)$ & - & - & - & - & - & - & - \\
\hline Methanol $\left(\mathrm{CH}_{3} \mathrm{OH}\right)$ & $5.36(3.27)$ & $0.80(0.28)$ & $2.26(1.27)$ & $0.39(0.39)$ & $54.9(27.9)$ & 1.01 & $4.14(0.88)$ & $0.94(1.25)$ \\
\hline Acetol $\left(\mathrm{C}_{3} \mathrm{H}_{6} \mathrm{O}_{2}\right)$ & $1.92(0.20)$ & - & - & - & $21.6(35.3)$ & - & $9.60(2.38)$ & - \\
\hline Phenol $\left(\mathrm{C}_{6} \mathrm{H}_{5} \mathrm{OH}\right)$ & $4.36(5.06)$ & $0.45(0.21)$ & 3.32 & - & $10.4(6.6)$ & - & $2.16(0.36)$ & - \\
\hline Furan $\left(\mathrm{C}_{4} \mathrm{H}_{4} \mathrm{O}\right)$ & $1.51(0.37)$ & $0.18(0.10)$ & 0.40 & - & $3.94(2.30)$ & - & $0.95(0.22)$ & - \\
\hline Formaldehyde (HCHO) & $1.69(1.62)$ & $0.83(0.25)$ & $2.08(0.86)$ & $0.37(0.40)$ & $3.62(2.42)$ & 0.60 & - & $0.62(0.13)$ \\
\hline Glycolaldehyde $\left(\mathrm{C}_{2} \mathrm{H}_{4} \mathrm{O}_{2}\right)$ & $2.62(4.18)$ & $0.23(0.20)$ & 1.42 & - & - & - & - & - \\
\hline Acetaldehyde $\left(\mathrm{CH}_{3} \mathrm{CHO}\right)$ & $2.81(1.36)$ & - & - & - & - & - & - & - \\
\hline Carbonyl Sulfide (OCS) & $1.20(2.21)$ & - & - & - & - & - & - & - \\
\hline Acetic Acid $\left(\mathrm{CH}_{3} \mathrm{COOH}\right)$ & $7.08(3.40)$ & $1.10(0.50)$ & $4.97(3.32)$ & 0.34 & $44.8(27.3)$ & 2.62 & $11.7(5.08)$ & $2.42(3.32)$ \\
\hline Formic Acid $(\mathrm{HCOOH})$ & $0.54(0.71)$ & $0.06(0.04)$ & $0.22(0.17)$ & 0.0048 & $0.68(0.20)$ & 0.063 & $0.46(0.31)$ & $0.18(0.12)$ \\
\hline Acetone $\left(\mathrm{C}_{3} \mathrm{H}_{6} \mathrm{O}\right)$ & $1.08(0.29)$ & - & - & - & - & - & - & - \\
\hline Hydrogen Cyanide (HCN) & $5.00(4.93)$ & $0.38(0.12)$ & - & - & $0.21(0.17)$ & - & $0.53(0.30)$ & 0.47 \\
\hline Methyl Ethyl Ketone $\left(\mathrm{C}_{4} \mathrm{H}_{8} \mathrm{O}\right)$ & - & - & - & - & - & - & - & - \\
\hline Hydrogen Chloride ( $\mathrm{HCl})$ & - & $0.17(0.14)$ & - & - & - & - & - & $3.61(3.27)$ \\
\hline Methyl Vinyl Ether $\left(\mathrm{C}_{3} \mathrm{H}_{6} \mathrm{O}\right)$ & 0.85 & - & - & - & - & - & - & - \\
\hline Acetonitrile $\left(\mathrm{CH}_{3} \mathrm{CN}\right)$ & $3.70(0.90)$ & - & - & - & - & - & - & - \\
\hline Sulfur Dioxide $\left(\mathrm{SO}_{2}\right)$ & - & $0.68(0.13)$ & - & - & - & - & 0.06 & 0.5 \\
\hline Hydrogen $\left(\mathrm{H}_{2}\right)$ & - & - & - & - & - & - & - & 0.091 \\
\hline Ammonia $\left(\mathrm{NH}_{3}\right)$ & $10.8(12.4)$ & $1.03(0.66)$ & $0.87(0.40)$ & 0.03 & $1.24(1.44)$ & 0.79 & $4.75(1.00)$ & $0.94(1.02)$ \\
\hline Nitrogen Oxides $\left(\mathrm{NO}_{\mathrm{x}}\right.$ as $\left.\mathrm{NO}\right)$ & $0.80(0.57)$ & $3.26(0.95)$ & $1.42(0.72)$ & - & $0.22(0.22)$ & 1.41 & 0.5 & $3.74(1.48)$ \\
\hline Nitrous Oxide $\left(\mathrm{N}_{2} \mathrm{O}\right)$ & - & $0.25(0.18)$ & - & - & - & 0.24 & - & - \\
\hline Nitrous Acid (HONO) & - & $0.41(0.15)$ & - & - & - & - & - & - \\
\hline TNMHC as $\mathrm{CH}_{4}$ & - & - & $2.89(1.21)$ & $3.76(4.53)$ & - & - & - & - \\
\hline TNMHC as $\mathrm{g} \mathrm{C}$ & - & - & $2.27(2.07)$ & - & - & - & - & - \\
\hline NMOC (identified) & $48.7(32.4)$ & $6.0(2.4)$ & $19.2(7.6)$ & $1.87(0.92)$ & $161(115)$ & 5.56 & $32.6(10.2)$ & $7.5(7.6)$ \\
\hline NMOC (identified + unidentified) ${ }^{\mathrm{e}}$ & 97.3 & 12.1 & 57.7 & 5.62 & 321 & 11.1 & 97.7 & 22.6 \\
\hline Total Suspended Particulate (TSP) & - & $15.4(7.2)$ & $4.55(1.53)$ & $3.34(1.68)$ & $0.7-4.2$ & 2.38 & - & - \\
\hline Total Particulate C & - & - & - & - & - & - & 22.9 & - \\
\hline $\mathrm{PM}_{2.5}^{\mathrm{f}}$ & - & $11.9(5.8)$ & $6.64(1.66)$ & - & - & - & - & $9.8(5.7)$ \\
\hline Black Carbon (BC) & $0.20(0.11)$ & 1.3 & $0.83(0.45)$ & $0.74(0.37)$ & $0.02(0.02)$ & $1.0^{\mathrm{g}}$ & $0.53^{\mathrm{g}}$ & $0.65(0.27)$ \\
\hline Organic Carbon (OC) & $6.23(3.60)$ & 3.7 & $2.89(1.23)$ & $1.92(0.90)$ & $0.74(0.72)$ & $1.3^{\mathrm{g}}$ & $1.8^{\mathrm{g}}$ & $5.27(4.89)$ \\
\hline
\end{tabular}

a See Sect. 2.3 for guidance in use. Emission factors are shown with an estimate of the natural variation in parenthesis, when available.

$\mathrm{b}$ EF include an assumed tropical forest overstory.

${ }^{c}$ EF reported in units of $g$ of compound emitted per $\mathrm{kg}$ of charcoal produced.

$\mathrm{d}$ EF reported in units of $\mathrm{g}$ of compound emitted per $\mathrm{kg}$ of charcoal burned.

${ }^{\mathrm{e}}$ Estimated (see Sect. 3.4).

${ }^{\mathrm{f}} \mathrm{PM}_{1}-\mathrm{PM}_{5}$ categorized as $\mathrm{PM}_{2.5}$.

$\mathrm{g}$ Source is Bond et al. (2004).

\subsubsection{Savanna}

The emission factors from one laboratory study and four airborne studies of savanna fires are presented and averaged in Table S1. The savanna fire average and variation is also reported in Table 1. We make several points about three of the included studies next. During the Smoke, Clouds, and Radiation-Brazil (SCAR-B) campaign, airborne EF measurements were made of fresh smoke from several different fire types. However, the EF were originally published as the overall regional average emission factors for the combination of all the different fire types observed (Ferek et al., 1998). We broke out the original fire-specific SCAR-B EF 
into the appropriate fire-type categories in our classification scheme based primarily on the recorded visual observations from the aircraft. However, the delineation between TDF and "wooded" or "humid" savanna fires was difficult from the aircraft and the distinction is often unclear in the literature as well. We categorized three of the SCAR-B fires as savanna fires because the Advanced Very High Resolution Radiometer (AVHRR) Continuous Fields Tree Cover product (DeFries et al., 2000) showed that the area burned had a pre-fire canopy coverage less than $40 \%$ (Matthews, 1983; Hansen et al., 2000). We used the AVHRR product because the fires burned prior to coverage by the MODIS VCF product (Hansen et al., 2003). The gas and particle emissions data from the SCAR-B fires are also converted to units of $\mathrm{g}$ compound per kg fuel. "Xylenes" are calculated from the sum of p-xylene, m-xylene, and o-xylene. Since $\mathrm{NO}$ and $\mathrm{NO}_{2}$ are rapidly interconverted in the atmosphere, we also calculate and report an EF for " $\mathrm{NO}_{\mathrm{x}}$ as NO". The estimate of the variation in the EF is taken as the standard deviation of the EF. The volume distribution for BB particles by aerodynamic diameter shows a minimum from about 1 to 5 microns (Ward and Radke, 1993). Thus, in all our tables, measurements of $\mathrm{PM}_{1.0}-\mathrm{PM}_{5.0}$ are grouped together as $\mathrm{PM}_{2.5}$ to allow averaging data from more studies. We also note that $\mathrm{PM}_{2.5}$ is usually close to $80 \%$ of $\mathrm{PM}_{10}$ or TPM when measured on the same BB sample (e.g. Artaxo et al., 1998). Finally, we group $\mathrm{EF}$ reported for elemental carbon (EC) or black carbon (BC) in a single "BC" category. If there are thermal and thermal-optical measurements of EC we take the results from the latter more advanced technique. Differences between the measurement techniques used for these species are the subject of ongoing research (Reid et al., 2005a, b; Bond and Bergstrom, 2006; Schwarz et al., 2008).

We include early dry season EF measured by Yokelson et al. (2011) in Mexico that may help our average EFs (Tables $\mathrm{S} 1$ and 1) better represent the full dry season. In addition, these early dry season EFs could be taken from Table S1 for an application targeted at that time of year.

We include EF from Christian et al. (2003) who measured emissions from burning grass and/or twig/leaf-litter fuels from Zambian humid savannas in 16 laboratory fires. Their reported uncertainty is $\pm 37 \%$ factoring in $31 \%$ naturally occurring variability in NMOC (Yokelson et al., 2003), 15\% prediction error (reflecting the uncertainty in using lab data to predict field emission factors for this fire type), and 5\% error in measurement. Alang-alang (Imperata cylindrica) is a widespread fire-maintained grass subject to frequent burning in Indonesia (Jacobs, 1988; Seavoy, 1975; Pickford et al., 1992) that was burned in five fires by Christian et al. (2003) and we categorize it as a savanna-type fuel. Most of the data reported by Christian et al. (2003) were collected using open path FTIR (OP-FTIR) and PTR-MS. For this study and other studies with EFs measured by both FTIR and PTR-MS, the FTIR could sometimes quantify individual species when multiple species appeared on the same mass in the PTR-MS.
In these cases, we select the FTIR data with a notable exception for acetol. The coupling and/or selection of data from various instruments is described in more detail in the original papers and by Christian et al. (2004) and Karl et al. (2007). The EF for $\mathrm{HCOOH}$ and glycolaldehyde published prior to 2011 in FTIR-based studies have been rescaled to be consistent with new reference spectra (Rothman et al., 2009; Johnson et al., 2010).

For this category and for the other categories, when sufficient data are available, we provide a conservative estimate of the "naturally-occurring variation" in the average EF for a group of fires within the classification. It is common to report variability as "uncertainty," but the measurement uncertainties associated with calculating individual EF are generally quite low for the studies we include in this compilation. We adopted a relatively simple approach to estimate the variability, which is described next in order of increasing complexity:

The case when only one study is available:

1. If there is only one EF value available, we do not estimate variability.

2. If there are only two EF values available, we estimate variability as the range.

3. If two or more EF values are given and both provide an estimate of variation, we average them to estimate variability.

4. If three or more EF values are given in just one study, we estimate variability as the standard deviation of the EF.

The case when two or more studies are available:

1. If more than one study reports EF, but only one study provides an estimate of variability, we estimate variability using the fractional variability from the one study provided.

2. If more than one study reports EF and an estimate of the variability, we took the average variability as our estimate of variability (we find that the range or standard deviation of study means can sometimes significantly underestimate natural variability).

3. When more than one study was available and there was a large difference in the amount of sampling between studies, we weighted the EF by the amount of sampling to derive a final average EF value reported in our tables, but our estimates of variation were obtained as above (without weighting).

4. Variability in total NMOC was taken as the sum of the variability of each individual NMOC (we find that equations propagating fractional uncertainties overemphasize the impact of compounds measured in low abundance on total variation). 
Users preferring an alternate calculation of averages or variation can implement their scheme using the original data, which can be found in Supplement Tables S1-S14.

\subsubsection{Boreal forest}

Boreal forest fires can consume large amounts of both aboveground and below-ground biomass (Ottmar and Sandberg, 2003; French et al., 2004). We include lab or groundbased measurements of EF for burning organic soils, peat, and woody/down/dead vegetation; the latter term including stumps, logs, and downed branches (Tables 1, S2). Such fuels are likely to burn by RSC, which can continue long after flaming and strong convection from a fire have ceased (Bertschi et al., 2003b). We computed the average for five common components of the fuel in boreal organic soils that were burned individually by Bertschi et al. (2003b) (identified as Lolo1, 2, 3, NWT 1, 2 in original work) and took the standard deviation as the variability. Emissions from burning organic soil from Alaska (identified as sedge, sphagnum moss, feather moss, white spruce, and forest floor duff) were reported by Yokelson et al. (1997), for which we compute EF using the reported C content. Yokelson et al. (1997) also reported emissions measurements for boreal peat from Alaska and Minnesota. Given that the $\% \mathrm{C}$ was not measured for Alaskan peat, we used the measured $\% \mathrm{C}$ for $\mathrm{MN}$ peat $(49.4 \%)$ in all of the boreal peat EF calculations. We also include Alaskan duff EF measured in a laboratory by Burling et al. (2010). Bertschi et al. (2003b) reported EF for woody/down/dead fuels (identified as Stump and Cwd 2), which are also included here. We are unaware of any measurements of the relative consumption of the different organic soil and woody fuel components for "typical boreal fires" so a straight average of the EF for the organic soil/duff and dead and down component in these lab/ground studies was used for a ground-based average (as shown in Table S2).

Four studies reported airborne measurements of boreal forest fire EF in fresh smoke for an extensive number of compounds. We include the average of the emission factors from three fires (B280, B349, and B309) sampled by Goode et al. (2000) (fire B320 was not included since the fuels were not representative of a boreal forest; see original work). Nance et al. (1993) and Radke et al. (1991) also reported boreal airborne EF measurements for one wildfire and four prescribed fires, respectively. These are included in this compilation. We include airborne EF measurements for boreal wildfires from the Arctic Research of the Composition of the Troposphere from Aircraft and Satellites (ARCTAS) campaign (Simpson et al., 2011). Whole air samples (canisters) were collected in smoke plumes over Saskatchewan, Canada. Emission factors for long-lived species were based on all the canisters collected in 5 plumes. EFs of "short-lived" $\left(k_{\mathrm{OH}} \geq 8.52 \times 10^{-12} \mathrm{~cm}^{3}\right.$ molecule $\left.\mathrm{s}^{-1} \mathrm{~s}^{-1}\right)$ species were calculated using only samples of fresh smoke collected $<7.3 \mathrm{~km}$ from the source.
Due to slow decomposition, large amounts of carbon are stored in boreal soils and dead/down woody fuels that burn by smoldering combustion and thus account for much of the total fuel consumption. To take this into consideration, we calculate the overall boreal forest fire EF in Table 1 (and Table S2) from a straight average of the airborne and groundbased EF averages, which is roughly equivalent to assuming $\sim 70 \%$ of the fuel consumption is by smoldering combustion. In fact, data in Table 4 of van der Werf et al. (2010) suggest that an even larger weighting of the ground-based "smoldering" EF could be appropriate. Using Table S2, EF can be calculated based on other relative contributions of flaming and smoldering. Some smoldering compounds were measured only from the air. For these compounds we multiply the airborne EF by the average ratio of the " $50-50$ " average to the airborne average $(2.02 \pm 0.070)$. A similar approach is used for smoldering compounds measured only from the ground; they were multiplied $0.70 \pm 0.11$ to obtain the 50-50 average. Finally, we point out that the flaming and smoldering emissions can have different injection altitudes, which could be important to recognize in some applications. For instance, the boreal airborne average in Table S2 would likely agree well on average with airborne measurements of fresh smoke from boreal forest fires, but the overall boreal average shown in Tables 1 and S2 may better represent the true average regional fire emissions.

\subsubsection{Tropical forest}

Our emission factors for tropical forest fires are in Table 1. We derive the EFs by averaging over several types of tropical forest fires in Table S3. For tropical evergreen forest deforestation fires we include EFs cited in Yokelson et al. (2008) and EFs retrieved from the original SCAR-B data of Ferek et al. (1998). The EFs in Yokelson et al. (2008) (all from the Tropical Forest and Fire Emissions Experiment - TROFFEE) were derived using a $0.05 / 0.95$ weighted average of the Christian et al. (2007) ground-based measurements (dominated by residual smoldering combustion) and the Yokelson et al. (2007a) airborne measurements (dominated by flaming combustion). For these types of fires, available evidence suggests that approximately 5\% of biomass consumption is by residual smoldering combustion and $95 \%$ of consumption is during the convective plume forming phase of the fire (Christian et al., 2007). The average of the EF for residual smoldering and the EF for initially lofted emissions, weighted by the above fuel consumption, gives fire-average EF for smoldering compounds that were $1.12 \pm 0.11$ times higher than the EF from just the airborne data. Thus, since some smoldering compounds were measured only in the air, their emission factors are computed from 1.12 times the airborne average in both this work and Yokelson et al. (2008). The EF and variation for pyrrole can be found in the discussion version of Yokelson et al. (2007a). The variation for all the other species is taken as the standard deviation in the airborne EF 
in Table 2 of Yokelson et al. (2007a). We also average EF from 12 airborne samples of fires from the SCAR-B campaign (Ferek et al., 1998) that represented emissions from six flaming and six smoldering fires classified as tropical evergreen deforestation fires. We do not make the small adjustment to the smoldering compounds for RSC in the SCARB data (Ferek et al., 1998). Average EF for the "subcategory" tropical evergreen deforestation fires are included in Table S3.

For tropical dry forest (TDF) fires we consider both deforestation and understory fire emissions. The studies we include are Yokelson et al. (2009, 2011), Ferek et al. (1998), and Sinha et al. (2004). Yokelson et al. (2011) report EFs for nine TDF fires sampled in Mexico (six of which were originally published in Yokelson et al., 2009). These were early dry season fires, which should help the average EF we derive for this category reflect the entire dry season since the other studies measured EF later in the dry season. We calculate an $\mathrm{EF}$ for nitrous acid (HONO) from the mass emission ratio $\Delta \mathrm{HONO} / \Delta \mathrm{NO}_{\mathrm{x}}$ measured on one tropical dry deforestation fire (Fire \#2 on 23 March 2006 from Yokelson et al., 2009) times our average $\mathrm{EF}\left(\mathrm{NO}_{\mathrm{x}}\right)$ for TDF. We classify three SCAR-B fires from Ferek et al. (1998) as TDF fires and estimate the variation as the standard deviation of these EF. Sinha et al. (2004) measured numerous emissions from one African tropical dry forest (Miombo) understory fire. That work includes an EF for condensation nuclei in the diameter range $0.003-3 \mu \mathrm{m}$ expressed as number of particles per kg fuel burned. Finally, in theory, to derive average EF for tropical dry forest fires from the available measurements we would need to know the relative importance of understory and deforestation burns in this ecosystem globally (Desanker et al., 1997). Since this information is not available to our knowledge, we weight them equally here to obtain average EF for TDF. We then weight all the studies in Table S3 equally to obtain the tropical forest fire average EF that we carry over to Table 1.

\subsubsection{Temperate forest}

We include the average and standard deviation of EFs from three temperate evergreen forest fires (two wild and one prescribed) from Radke et al. (1991) and seven pine-oak forest fires sampled in remote mountain areas of Mexico by Yokelson et al. (2011), as seen in Table S4. We do not include the EFs for pine-oak forest fires measured in the Mexico City area by Yokelson et al. (2007b), since they were likely at least partially affected by nitrogen deposition from the urban area. We also include the average and standard deviation of the preliminary EFs from a recent study that sampled two prescribed understory fires in coniferous forest in the Sierra Nevada Mountains of California and six prescribed understory fires in coniferous forest in coastal North Carolina (Burling et al., 2011).

\subsubsection{Peatland}

Peat burns almost entirely by smoldering combustion. Christian et al. (2003) made laboratory measurements on a single Indonesian peat fire. We provide no estimate of variation for EF from Christian et al. (2003) as only one fire was measured, though a general range of at least $20-40 \%$ uncertainty could be assumed. The boreal peat EF reported in Yokelson et al. (1997) and considered in calculating the boreal forest EF (Table S2) are also used in computing our global peatland EF in Table S5. The Indonesian peat sample had a $54.7 \%$ carbon content, which contributed to a significantly higher $\mathrm{EF}\left(\mathrm{CO}_{2}\right)$ compared with boreal peat, but we do not imply that tropical peat always has higher $\mathrm{C}$ content. We calculated the average peat EF in Table S5 by averaging the studies of boreal (Yokelson et al., 1997) and Indonesian (Christian et al., 2003) peat and estimate an average variability from the fractional variation in EF in Yokelson et al. (1997). Smoldering peat accounts for the bulk of the emissions from most fires in peatlands and our average peat EFs in Table S5 are based only on the smoldering peat measurements. However, Page et al. (2002) estimated that $0.19-0.23$ Gt of carbon was released into the atmosphere through peat combustion in tropical peat swamp forests, while $0.05 \mathrm{Gt}$ of carbon was released from overlying vegetation during the $1997 \mathrm{El}$ Niño year in central Borneo. From these estimates we took a weighted average of the peat EFs (73\%) in Table S5 with the tropical evergreen forest deforestation fire EFs (27\%) in Table $\mathrm{S} 3$ to derive a peatland average shown in Table 2 that accounts for consumption of a (tropical) forest overstory. The user can apply the average EFs most suited to their application.

\subsubsection{Chaparral}

We include the average EF from three studies that measured emissions from California chaparral fires. The average EF from three fires sampled by Radke et al. (1991) was taken (Eagle, Lodi 1, and Lodi 2). We converted their $\mathrm{EF}\left(\mathrm{NO}_{\mathrm{x}}\right)$, which assumes a 50/50 mix to an EF for " $\mathrm{NO}_{\mathrm{x}}$ as NO" by multiplying their original $\mathrm{EF}$ by a mass factor of (30/38). We include the emission factors from a laboratory study that sampled $\sim 40$ carefully replicated fires in six types of chaparral fuels (Burling et al., 2010). We also include the average $\mathrm{EF}$ from five chaparral fires measured during a recent field campaign (Burling et al., 2011). The emission factors from the latter campaign are flagged as preliminary, but subject to only minor changes by the time of publication.

\subsubsection{Open cooking}

Christian et al. (2010) reported the average EF of eight open cooking fires sampled in Mexico. Brocard et al. (1996) and Brocard and Lacaux (1998) reported the average emission factors for 43 open cooking fires in Ivory Coast. We 
multiply their $\mathrm{EF}$ and variation by $\mathrm{MW}_{\mathrm{X}} / \mathrm{MW}_{\mathrm{C}}$ to convert from $\mathrm{g} \mathrm{C} \mathrm{kg}^{-1}$ dry fuel to $\mathrm{g} \mathrm{X} \mathrm{kg}^{-1}$ dry fuel. Some updated EF reported by Brocard and Lacaux (1998) supersede those found in Brocard et al. (1996). Smith et al. (2000) sampled six open cooking fires in a lab using Indian fuels: variation was taken as the fractional variation in ER as seen in Bertschi et al. (2003a). We include the EF measured by Zhang et al. (2000) for wood burning in open stove types in China and EF measurements made in Honduras for traditional open "stoves" (designated as "no chimney") from Roden et al. $(2006,2009) . \mathrm{CO}_{2}$ data were not included in the published work of the latter, but were graciously provided by Tami Bond and Christoph Roden. Johnson et al. (2008) included EF for 8 open cooking fires in Mexico, which we convert from $\mathrm{g} \mathrm{C} \mathrm{kg}^{-1}$ fuel to $\mathrm{g} \mathrm{X} \mathrm{kg}^{-1}$ fuel. Bertschi et al. (2003a) report the average EF for three open wood cooking fires in Zambia and we estimate variation from the fractional variation in their ER. We weight all 8 included studies equally to obtain the average EF shown in Tables 2 and S7.

\subsubsection{Patsari cooking stoves}

We assume a fuel $\mathrm{C}$ content of $50 \%$ when converting all cook stove ER to EF. Christian et al. (2010) analyzed 26 samples collected from chimney outlets of two Patsari stoves in Mexico. Our estimate of variation is the range in the two EF measurements. We also include Patsari stove EF measurements from Johnson et al. (2008) made in 13 homes in Mexico. We report the overall Patsari stove average emission factors and variation in Tables 2 and $S 8$.

\subsubsection{Charcoal making}

Most of the global charcoal production is carried out in temporary kilns constructed mainly from dirt (Bertschi et al., 2003a). Charcoal making EF have been reported in the literature in at least four types of units: $\mathrm{g}$ compound or $\mathrm{gC}$ emitted, referenced to either $\mathrm{kg}$ of wood used or $\mathrm{kg}$ of charcoal made. We convert as needed and report all EF here in units of $\mathrm{g}$ compound per $\mathrm{kg}$ charcoal produced. In Bertschi et al. (2003a), the kiln was charged with a tree species with a known carbon content of $48 \%$ (Susott et al., 1996). Coupling several other studies they concluded that $\sim 45 \%$ of the wood carbon is given off as gases so that approximately $216 \mathrm{~g} \mathrm{C}$ is volatilized per $\mathrm{kg}$ of dry wood used. Dividing up those $216 \mathrm{~g}$ according to their measured ER (which included the major emissions $\mathrm{CO}_{2}, \mathrm{CO}$, and $\mathrm{CH}_{4}$ ) then allowed straightforward calculation of the reported EF per $\mathrm{kg}$ wood used. Conversion to EF per $\mathrm{kg}$ charcoal produced was based on assuming an average charcoal yield per mass of dry wood of $28 \%$, a factor that varies little between the many reported measurements (Bertschi et al., 2003a; Chidumayo, 1994; Pennise et al., 2001; Lacaux et al., 1994; Smith et al., 1999). Bertschi et al. (2003a) obtained their ER from averaging three 1$2 \mathrm{~h}$ measurements made on one kiln on three different days spread over the 4 days required to produce a batch of charcoal. They then derived EF as just described. Christian et al. (2010) made 36 spot measurements of ER (with $\sim 1$ min sampling time) during days 2-5 from three kilns that had 8day "lifetimes"; they then converted to EF with the procedure of Bertschi et al. (2003a). Our estimate of variation for Bertschi et al. (2003a) and Christian et al. (2010) is the fractional uncertainty in ER. Christian et al. (2007) made three spot measurements (1 min sampling time) from a single kiln in Brazil; however, measurements were made only in the last stage of the kiln lifetime and may not be representative of emissions occurring throughout the charcoal making process. The FTIR-based studies of Bertschi et al. (2003a) and Christian et al. $(2007,2010)$ measured a substantially different suite of NMOC than the other available studies and also differed in sampling approach so data from these 3 studies was averaged together separately using the weighting factors described next. Since Christian et al. (2007) collected only three $1 \mathrm{~min}$ spot measurements, we employed a weighting factor $(4 \%)$ based on the minutes of actual sampling. The kiln measurements of Christian et al. (2010) and Bertschi et al. (2003a) were roughly equivalent in the extent of sampling and were weighted equally at $48 \%$. The FTIR-based average values were then averaged with 4 other studies to obtain the overall charcoal making EF shown in Tables 2 and S9. The four additional studies are described next. Lacaux et al. (1994) continuously monitored the emissions from a charcoal kiln in the Ivory Coast over its whole "lifetime". We assume that any differing $\mathrm{EF}$ found in a later paper that discusses that project (Brocard and Lacaux, 1998) supersede those found in Lacaux et al. (1994). We also include EF from Smith et al. (1999) and Pennise et al. (2001) measured in Thailand and Kenya, respectively.

\subsubsection{Charcoal burning}

We report all EF in units of $\mathrm{g}$ compound per $\mathrm{kg}$ charcoal burned (Tables 2 and S10). Unless otherwise stated, the charcoal fuel carbon content was assumed to be $72 \pm 3 \%$ (Lacaux et al., 1994; Chidumayo, 1994; Ishengoma et al., 1997; Smith et al., 1999). We recalculate the EF from the ER reported in Bertschi et al. (2003a) and a few of our EF values differ slightly from those originally reported in their work. No variation was reported for the Bertschi et al. (2003a) study as emissions were measured from only one fire. Brocard et al. (1998) reported ER and fractional variation in those ER for charcoal burning, which we converted to EF. For the compounds they reported relative to $\mathrm{CO}_{2}$, we estimate variation from the fractional variation in the ER. To estimate variation for the compounds they reported relative to $\mathrm{CO}$, we also consider their uncertainty in $\Delta \mathrm{CO} / \Delta \mathrm{CO}_{2}$. We include Smith et al. (2000) and Kituyi et al. (2001) EF measured in India and Kenya, respectively. 


\subsubsection{Dung}

Keene et al. (2006) reported the median EF of gases and total particulate carbon from two laboratory fires that burned dung collected in India. Christian et al. (2007) measured the emissions from three burning cattle dung piles encountered on a subsistence farm in Brazil. We calculate all EF assuming a $32.6 \%$ fuel carbon content on a dry weight basis, as reported by Keene et al. (2006). We compute a weighted average based on the number of samples from each study (Tables 2 and S11).

\subsubsection{Pasture maintenance}

In Brazil many cattle ranches have been established in areas that were previously tropical forest. Pasture maintenance fires are used to prevent the re-establishment of the forest and they burn both grass and residual wood from the original forest. Within Brazil, these fires are estimated to consume as much biomass annually as primary deforestation fires (Kauffman et al., 1998). Pasture maintenance fires are thought to be much less abundant in most other tropical forest areas. Yokelson et al. (2007a) sampled one Brazilian pasture fire from an airborne platform (Table S12). We include no estimate of variation as only one fire was measured. The EF for pyrrole for that fire was reported in the discussion version of Yokelson et al. (2007a). The SCAR-B study of Ferek et al. (1998) included airborne samples of six pasture fires. We use the standard deviation in EF from their pasture fire measurements to estimate the variability in $\mathrm{EF}$ and we compute a weighted airborne average EF based on the number of fires sampled in these two studies. A significant fraction of the fuel consumption in pasture fires produces unlofted emissions via residual smoldering combustion of the residual woody debris (RWD) from the former forest (Barbosa and Fearnside, 1996; Guild et al., 1998; Kauffman et al., 1998). These emissions must be sampled from the ground. We are aware of one ground-based study (Christian et al., 2007) that reported EF for RSC of RWD in pastures, and we also obtained originally unpublished EF from that study for " $\mathrm{NO}_{\mathrm{x}}$ as $\mathrm{NO}$," $\mathrm{NO}$, and $\mathrm{NO}_{2}$. For all species with both airborne and ground-based data we obtained a "EF(total)" for pasture fires from a weighted average based on the assumption that $40 \%$ of the fuel consumption was by RSC and $60 \%$ generated lofted emissions that could be sampled from the air (Christian et al., 2007).

Some compounds were measured only from the air. The $\mathrm{EF}$ (total) for the smoldering compounds that were measured only from an aircraft is estimated by multiplying the average $\mathrm{EF}$ (air) by $2.00 \pm 0.90$, which was the average value of the ratio $\mathrm{EF}$ (total)/EF(air) for smoldering compounds not containing $\mathrm{N}$ that were measured from both platforms (Yokelson et al., 2008). Two flaming compounds were measured only from the air. $\mathrm{EF}$ (total) for $\mathrm{SO}_{2}$ is estimated by multiplying $\mathrm{EF}$ (air) for $\mathrm{SO}_{2}$ by $\mathrm{EF}$ (air)/EF(total) for $\mathrm{NO}_{\mathrm{x}}$ which was measured from both platforms. Our estimate of $\mathrm{EF}(\mathrm{HONO})$ is obtained by multiplying the $\Delta \mathrm{HONO} / \Delta \mathrm{NO}_{\mathrm{x}}$ mass ER in Yokelson et al. (2007a) times our final $\mathrm{EF}\left(\mathrm{NO}_{\mathrm{x}}\right)$. Two smoldering compounds were measured only on the ground. $\mathrm{EF}$ (total) for acetol (1hydroxy-2-propanone, $\left.\mathrm{C}_{3} \mathrm{H}_{6} \mathrm{O}_{2}\right)$ and phenol $\left(\mathrm{C}_{6} \mathrm{H}_{6} \mathrm{O}\right)$ are estimated by multiplying the $\mathrm{EF}$ (ground) times the average $\mathrm{EF}$ (total)/EF(ground) for the (non-N) smoldering compounds measured from both ground and air. We use the fractional variation in the ground-based EF to estimate the variation in species with ground or both ground and airborne data, since ground-based data appear to have greater variability than airborne data (see Figs. 2 and 4 in Yokelson et al., 2008). For species with only airborne data we estimate the uncertainty as $45 \%$ (Yokelson et al., 2008) (Table 1).

\subsubsection{Crop residue}

Post harvest crop residue is a fine fuel that burns directly in the field and mostly by flaming in many mechanized agricultural systems. In contrast, when crops are harvested by hand the residue is often burned in large piles that may smolder for weeks. Yokelson et al. (2009) reported emission factors from airborne measurements of six crop residue fires associated with mechanized agriculture in the Yucatan, Mexico. Christian et al. (2010) made ground-based measurements of EF from mostly smoldering combustion during two similar burns in Central Mexico. Yokelson et al. (2011) made airborne measurements of the EFs for 6 additional crop residue fires associated with mechanized agriculture in central Mexico and derived overall averages that included their EFs and those from Yokelson et al. (2009) and Christian et al. (2010). We use the overall averages for mechanized agriculture from Yokelson et al. (2011) in Table S13. Christian et al. (2003) measured the mostly smoldering emissions from three laboratory fires burning manually piled Indonesian rice straw. Because of the significantly different EFs for these agricultural burning types it would be preferable to apply the specific EFs for each type of agriculture, when possible, by referring to Table S13 and the original papers. Because some users may require or prefer a global average for this category we present an estimate of this in Tables 1 and S13. In our overall average for crop residue fires, the EFs from the manual and mechanical agriculture subcategories are weighted based on the number of fires sampled, which is equivalent to assuming a 3:14 ratio of manual to mechanized harvesting on the global scale. The actual value of this ratio is not known to us and the reader can adjust the weighting if they prefer. In addition, because of the very large difference in EFs for these two types of burning, for this category only, we calculated the overall average by assuming a value of zero for the EF of 13 species that were not detected from fires associated with mechanical agriculture, but very high from smoldering rice straw (see Table S13). This procedure gives a weighted 
EF value for these 13 compounds that is more consistent with the overall average values for the other compounds.

\subsubsection{Garbage burning}

We consider field and laboratory measurements from Christian et al. (2010) and Lemieux et al. (2000), respectively. Christian et al. (2010) made 72 spot measurements at four Mexican landfills using a rolling, land-based FTIR and filter sampling apparatus. Emission factors were computed assuming the landfill waste was $40 \% \mathrm{C}$ by mass. Their estimate of $\mathrm{EF}\left(\mathrm{PM}_{2.5}\right)$ is the sum of particle components measured on quartz filters with a small allowance for unmeasured species (Christian et al., 2010). We report the average $\mathrm{EF}\left(\mathrm{PM}_{2.5}\right)$ and $\mathrm{EF}(\mathrm{HCl})$ from Lemieux et al. (2000) for the burning of recycled and non-recycled waste in barrels. We obtain the average from four "runs" - emissions from two avid recyclers and two non-recyclers - with $\mathrm{PM}_{2.5}$ emissions from non-recyclers notably higher than those of avid recyclers (see Table 1 in Lemieux et al., 2000 for study details and garbage composition). We include airborne EF measurements from a garbage burning fire in Mexico (Yokelson et al., 2011). We also include the few available USEPA (1995) AP-42 EF for open burning of municipal waste.

\subsection{Estimates of biomass loading and biomass consumption}

To project total emissions from a fire or region the EF presented above must be multiplied by the mass of biomass consumed in the fire or region. For open burning the total mass of biomass consumed is usually estimated from the product of two other estimates: (1) the mass of biomass consumed per unit area, and (2) the area burned. Airborne or ground-based measurements of the area of individual burn scars can be fairly accurate, but they are usually not available for the tropics and space-based measurements of burned area are still highly uncertain (Korontzi et al., 2004; Roy and Boschetti, 2009; Giglio et al., 2006, 2010). The biomass consumption per unit area has been measured for examples of most major types of open burning. Another approach involves calculating the fraction of the total biomass that was exposed to a fire that actually burned to determine a combustion factor (sometimes called "combustion completeness"). The combustion factor (CF) can then be multiplied by spatially varying estimates of biomass loading (Brown and Lugo, 1992; Brown, 1997) to estimate the biomass consumption per unit area for any burned location. The CF need not be a constant for an ecosystem. The small diameter biomass components in a "fuel complex" tend to have larger CFs than the larger diameter biomass components (Table 2 in Kauffman et al., 2003). Considering the season of CF measurements (available in the references for Table 3) reveals that $\mathrm{CF}$ tend to increase strongly as periods of dry weather lengthen and dry out the larger diameter fuels (van der Werf et al., 2006). Additional variation in CF results from natural variation at burn time in any of numerous factors that affect fire behavior such as relative humidity, temperature, winds, fuel geometry, etc. (Kauffman et al., 2003). For example, CF for Brazilian pasture fires ranged from 21-83\% due mainly to variable consumption of the large diameter residual woody debris (Kauffman et al., 1998; Guild et al., 1998). In southern Africa the percentage of available fuel that burned in understory fires in June (at the beginning of the dry season) in the Miombo tropical dry forest was $1 \%$ and 22\% ( $n=2$, Hoffa et al., 1999), while Shea et al. (1996) observed that $74 \%$ and $88 \%(n=2)$ of the understory fuels burned in Miombo fires in late August-early September (their Table 4). We have compiled many of the literature data for biomass loading, combustion factor, and biomass consumption sorted by vegetation/fire type in Table 3. GFED3 estimates for biomass consumption are also shown in Table 3 whenever their regional estimates for fuel consumption per unit area were likely dominated by one vegetation type. GFED estimates $46 \%$ higher biomass consumption for North American boreal fuel types compared to the average of the other referenced measurements. However, estimates of Asian boreal biomass consumption by GFED lie within 4\% of the average of the few measurements. A comparison for other fire types is difficult because the GFED biomass consumption data is presented by geographic regions that usually contain multiple fire types (van der Werf et al., 2010).

\subsection{Global emission estimates}

Operationally, most global models use temporally and spatially explicit products such as monthly GFED (van der Werf et al., 2006, 2010) or hourly FLAMBE (Reid et al., 2004, 2009) to generate open burning emissions over the course of a model run. However, estimates of the total annual biomass consumed globally by all the various fire types are needed, at the global scale, to assess the importance of various fire types, to develop emissions inventories for an average or model year, and to factor into budgets. We report several global estimates of combusted biomass (dry matter) for different fire types in Table 4. The individual estimates are based on data collected anywhere from 19872000, which explains some of the variability in comparisons. Global estimates from Andreae and Merlet (2001) and Bond et al. (2004) agree well for the main types of open burning: savanna, forest, and crop residue fires. The annual means for 1997-2009 from GFED3 (van der Werf et al., 2010) are about $20 \%$ lower than the widely used estimates in Andreae and Merlet (2001) for both savanna burning (2460 versus $3160 \mathrm{Tg}$ ) and total forest burning (1591 versus $1970 \mathrm{Tg}$ ). The Andreae and Merlet (2001) estimate of crop residue burning is about $75 \%$ higher than GFED3, but the latter assume that they underestimate this source. Kopacz et al. (2010) suggest that GFED3 underestimates BB in several important tropical regions. Detailed discussion and comparison of 
Table 3. Biomass loading, combustion factor, and biomass consumption estimates for various fuel types.

\begin{tabular}{|c|c|c|c|c|c|c|}
\hline Fuel Type & Reference & Location & Vegetation specifics & $\begin{array}{l}\text { Biomass } \\
\text { Loading } \\
\left(\mathrm{Mg} \mathrm{ha}^{-1}\right)\end{array}$ & $\begin{array}{l}\text { Combustion } \\
\text { Factor } \\
(\%)\end{array}$ & $\begin{array}{l}\text { Biomass } \\
\text { Consumption } \\
\left(\mathrm{Mg} \mathrm{ha}^{-1}\right)\end{array}$ \\
\hline Tropical Dry & Kauffman et al. (2003) & Mexico & Deforestation & $118.2-134.9$ & $62.4-80.2$ & $73.7-108.1$ \\
\hline \multirow[t]{6}{*}{ Forest } & Kauffman et al. (1993) & Brazil & Deforestation & 73.8 & 87 & 64 \\
\hline & Jaramillo et al. (2003) & Mexico & Deforestation & 112.2 & - & - \\
\hline & Shea et al. (1996) & Zambia & Understory & $5.1-5.8$ & $88-74$ & $4.5-4.3$ \\
\hline & Hoffa et al. (1999) & Zambia & Understory & 10.4 & 22.3 & 2.30 \\
\hline & Ward et al. (1992) & Brazil & & 9.3 & 78 & 7.3 \\
\hline & van der Werf et al. (2010), GFED3 & Central America & Central America (CEAM) & - & - & 29.8 \\
\hline \multirow{8}{*}{$\begin{array}{l}\text { Evergreen Tropical } \\
\text { Forest }\end{array}$} & Ward et al. (1992) & Brazil & & 292.4 & 53 & 155 \\
\hline & Fearnside et al. (1993) & Brazil & & 265 & 27.5 & 73 \\
\hline & Carvalho Jr. et al. (1998) & Brazil & & 401.5 & 20.47 & 82 \\
\hline & Carvalho Jr. et al. (2001) & Brazil & & 496 & 50 & 248 \\
\hline & Hughes et al. (2000) & Mexico & & 403 & 95 & 380 \\
\hline & Kauffman et al. (1995) & Brazil & & 355.4 & 51.6 & 185 \\
\hline & Guild et al. (1998) & Brazil & & 354.8 & 47 & 167 \\
\hline & van der Werf et al. (2010), GFED3 & Equatorial Asia & Equatorial Asia (EQAS) & - & - & 190 \\
\hline \multirow[t]{3}{*}{ Crop Residue } & Zárate et al. (2005) & Spain & Cereal crops & - & 80 & 1.14 \\
\hline & Hughes et al. (2000) & Mexico & Cornfield & 23 & - & - \\
\hline & Lara et al. (2005) & Brazil & Sugarcane & - & - & 20 \\
\hline \multirow[t]{2}{*}{ Peatland } & Page et al. (2002) & Indonesia & Peat plus overstory & - & - & 510 \\
\hline & Ballhorn et al. (2009) & Indonesia & Peat only & - & - & 383 \\
\hline \multirow[t]{5}{*}{ Pasture } & Hughes et al. (2000) & Mexico & & 24 & - & - \\
\hline & Guild et al. (1998) & Brazil & & 66.3 & 31 & 21 \\
\hline & Kauffman et al. (1998) & Brazil & & $53-119$ & $21-84$ & $24.5-44.5$ \\
\hline & Kauffman et al. (2003) & Mexico & & $29.0-40.3$ & $75-63$ & $21.8-25.4$ \\
\hline & Jaramillo et al. (2003) & Mexico & & 26.9 & - & - \\
\hline \multirow[t]{3}{*}{ Savanna } & Ward et al. (1992) & Brazil & Tropical savanna & 7.2 & 99 & 7.1 \\
\hline & Savadogo et al. (2007) & West Africa & Woodland savanna & - & - & 4.1 \\
\hline & Shea et al. (1996) & South Africa & & 3.8 & 76 & 2.9 \\
\hline \multirow[t]{10}{*}{ Boreal Forest } & Goode at al. (2000) & Alaska, USA & & - & - & 36 \\
\hline & S. Drury (unpublished data, 1998) & Alaska, USA & Wildfire B309, 28 June 1997 & - & - & 37 \\
\hline & van der Werf et al. (2010), GFED3 & North America & $\begin{array}{l}\text { Boreal North America } \\
\text { (BONA) }\end{array}$ & - & - & 53.2 \\
\hline & FIRESCAN Science Team (1996) & Bor Forest Island, Siberia & Prescribed crown fire & - & - & 38 \\
\hline & Cofer III. et al. (1998) & Northwest Territories, Canada & Prescribed crown fire & - & - & 42.7 \\
\hline & van der Werf et al. (2010), GFED3 & Asia & Boreal Asia (BOAS) & - & - & 39.6 \\
\hline & Kasischke et al. (1999) & Global estimate & & - & - & $10-60$ \\
\hline & Stocks (1991) & Global estimate & & - & - & 25 \\
\hline & Cahoon Jr. et al. (1994, 1996) & Global estimate & & - & - & 25 \\
\hline & de Groot et al. (2009) & Canada & & - & - & 22 \\
\hline \multirow[t]{5}{*}{ Temperate Forest } & Sah et al. (2006) & Florida, USA & Florida Keys pine forests & 60.6 & - & - \\
\hline & Snyder (1986) & Florida, USA & Everglades NP & $75-90$ & - & - \\
\hline & van der Werf et al. (2010), GFED3 & North America & $\begin{array}{l}\text { Temperate North America } \\
\text { (TENA) }\end{array}$ & - & - & 12.5 \\
\hline & Yokelson et al. (2007b) & Mexico & Pine dominated forest & - & - & $6.5-32$ \\
\hline & Campbell et al. (2007) & Oregon, USA & Mixed conifer forest & - & - & $34-44$ \\
\hline \multirow[t]{4}{*}{ Chaparral/Shrub } & Cofer III. et al. (1988) & S. California, USA & Chaparral & - & - & $20-70$ \\
\hline & Clinton et al. (2006) & S. California, USA & Chaparral & 28.3 & - & - \\
\hline & Ottmar et al. (2000) & S. California, USA & Chaparral & - & - & 15.0 \\
\hline & Hardy et al. (1996) & S. California, USA & Chaparral & - & - & 24.5 \\
\hline
\end{tabular}

current inventories can be found in Reid et al. (2009), Kopacz et al. (2010), Wiedinmyer et al. (2010) and the references therein. Yevich and Logan (2003) estimated biofuel biomass consumption at $2447 \mathrm{Tg} \mathrm{yr}^{-1}$ for 1985 , which suggested a dominant role of biofuels in global emissions even $25 \mathrm{yr}$ ago. They also estimated that biofuel use was growing at $20 \%$ per decade. Consistent with that growth, Bond et al. (2004) and Fernandes et al. (2007) independently estimated higher biofuel use for 1996 and 2000, respectively. If savanna burning remains constant on average, biofuel burning could overtake it as the primary source of BB emissions by approximately 2030; assuming the average emissions presented in Table 4 
Table 4. Global estimates of biomass consumption in units of mass of dry matter burned (Tg) per year.

\begin{tabular}{|c|c|c|c|c|c|c|c|}
\hline Year measured & 1990’s & mid 1990's & 2000 & $1993 / 1995$ & 1985 & & \\
\hline Forest & 1970 & 1939 & - & - & - & - & 1955 \\
\hline Tropical forest & 1330 & - & - & - & - & - & 1330 \\
\hline Cooking Stoves & - & - & 1351 & - & - & - & 1351 \\
\hline Open Cooking (fuelwood) & - & - & & 1062 & 1714 & - & \\
\hline Charcoal Burning & 38 & - & 39 & 24 & & - & 39 \\
\hline Charcoal Making & 43 & - & - & & - & - & 43 \\
\hline Crop Residue (for biofuel) & - & - & 495 & - & 597 & - & 546 \\
\hline Dung & - & - & 75 & - & 136 & - & 106 \\
\hline Garbage Burning & - & - & - & - & - & 1000 & 1000 \\
\hline
\end{tabular}

a Source is Andreae and Merlet (2001). Value of $640 \mathrm{Tg} \mathrm{yr}^{-1}$ is cited in original work as "extratropical forest", which encompasses both boreal and temperate forest types. "Biofuel" global estimate derived from the sum of biofuel burning, charcoal making, and charcoal burning estimates. Charcoal making estimate of 43 Tg yr ${ }^{-1}$ was calculated assuming a $27 \%$ charcoal yield (Bertschi et al., 2003a). The biomass consumption estimates were derived using methods described in Lobert et al. (1999).

b Source is Bond et al. (2004). Estimates from Table 4 in original work.

c Source is Fernandes et al. (2007). Original work defines "biofuel" as fuelwood (open cooking), charcoal burning, crop residues and dung.

d Source is Ludwig et al. (2003).

e Source is Yevich and Logan (2003). "Biofuel" defined as woodfuel, charcoal burning, crop residues and dung.

f Other. Garbage burning estimate of $1000 \mathrm{Tg} \mathrm{yr}^{-1}$ from Christian et al. (2010), peat estimate of $3400 \mathrm{Tg} \mathrm{yr}^{-1}$ from Page et al. (2002), and pasture maintenance estimate of $240 \mathrm{Tg} \mathrm{yr}^{-1}$ from Yokelson et al. (2008).

represent global emissions from the year 2003 with a $20 \%$ growth rate per decade. This projection is included to highlight the importance of biofuel use, but it is based mostly on past population/development trends and a rigorous projection of future trends is beyond the scope of this work. In general, large uncertainties in biofuel use stem from the difficulty in monitoring its usage in developing countries (Bond et al., 2004). The magnitude of industrial biofuel use remains especially uncertain given the diverse range of fuels used and the subjectivity of user surveys coupled with financial and legal issues for micro-enterprises, which form a large part of the economy of the developing world (Christian et al., 2010). A quantity with extreme uncertainty is the amount of global garbage burning with estimates ranging up to $1000 \mathrm{Tg} \mathrm{yr}^{-1}$ (Christian et al., 2010 and references therein).

\section{Discussion}

We begin this section with a brief comparison to two widely used compilations of emission factors and then provide guidance on estimating EFs for individual, unmeasured species. We then discuss a few individual BB emissions that are important as a radical source (HONO) or for use as BB tracers ( $\mathrm{HCN}, \mathrm{CH}_{3} \mathrm{CN}$ ) and for which a significant amount of new information has been recently obtained. We then briefly discuss progress in NMOC measurements as well as the large amount of NMOC emitted by BB that so far remain unidentified. We offer a new estimate for total global BB NMOC emissions. An overview of the sparse information available about atmospheric processing of $\mathrm{BB}$ emissions is presented. We then conclude with a brief summary of the state of the field identifying a few key gaps in our knowledge that should be targeted for future research.

\subsection{Summary comparison to previous compilations}

Because of the large number of compounds and fire types involved, a comprehensive comparison of the EFs presented here to all previous compilations is beyond the scope of this paper. In this section we present an overview comparison of our open burning EFs with the widely used review of Andreae and Merlet (2001, hereafter AM2001). We also compare our biofuel EFs with those in the extensive reference work of Yevich and Logan (2003). We acknowledge that a comparison of 2011 values to those from 2001 or 2003 should be seen partly as documentation of how values evolve as new information becomes available rather than as a traditional direct comparison. In addition, more than one 
averaging scheme may be adequate or appropriate since the applications of these data are diverse. In particular, AM2001 takes an inclusive approach while we take a highly selective approach, with each having their own strengths and weaknesses. An overly selective approach may inadvertently omit useful data while the full literature average may not reflect the ecosystem average for a large variety of reasons discussed earlier. The fact that many compounds are close in all compilations suggests some additional confidence for those species. A user may be well-advised to consider all compilations and the original work in many applications.

To keep the discussion at a reasonable length and focus it on differences outside the commonly observed variability, we limit our comparison to AM2001 to "major" emissions for which the recommended EF changed by more than $50 \%$ between 2001 and 2011. We loosely define major emissions as those with $\mathrm{EF}>0.2 \mathrm{~g} \mathrm{~kg}^{-1}$ in our compilation. As an exception, we track the $\mathrm{NO}_{\mathrm{x}}$ and $\mathrm{PM}_{2.5}$ EFs even when they do not meet these two selection criteria since they are critical to so many applications. Many other major emissions differ by less than $50 \%$ and many minor emissions change by more than $50 \%$, but they are not discussed here. The comparison is influenced by the fact that AM2001 provided best guesses for a significant number of unmeasured species while we do not. Instead, we discuss application-specific options for estimating values for unmeasured species separately in Sect. 3.2. In addition, we discuss $\mathrm{HONO}, \mathrm{HCN}$, and $\mathrm{CH}_{3} \mathrm{CN}$ in separate sections following this overview.

We make three general points before discussing specific compounds. We provide averages for 8 fire types not found in AM2001: boreal forest, temperate forest, chaparral, cooking stoves, peat, dung, pasture maintenance, and garbage burning, with possibility for even further subdivision using the Supplement Tables. For many fire types we include some new major emissions: e.g. HONO (see also Sect. 3.3), acetol, and glycolaldehyde. Our PM EFs are generally modestly higher.

We present a compact summary of the comparison with AM2001 for the selected major EFs in Fig. 1, where the black columns indicate the ratio of our EF to the AM2001 $\mathrm{EF}$ for each species. If a species has a blue column, this indicates that a EF was not available in AM2001 and, for the blue columns only, the height shows our actual EF in $\mathrm{g} \mathrm{kg}^{-1}$ to verify that it is a major emission. For example, referring to the top panel of Fig. 1 (savanna fires), we see that our $\mathrm{EF}\left(\mathrm{C}_{2} \mathrm{H}_{6}\right)$ is 2.06 times higher than the $\mathrm{EF}\left(\mathrm{C}_{2} \mathrm{H}_{6}\right)$ in AM2001. For phenol, our EF is 175 times larger than that reported in AM2001 as indicated by the number above the column. While our values are higher for most of the EFs shown, the AM2001 values are significantly higher for $\mathrm{NH}_{3}$ and $\mathrm{HCOOH}$. Our EF for $\mathrm{NO}_{\mathrm{x}}$ is identical to that in $\mathrm{AM} 2001$ and our $\mathrm{EF}\left(\mathrm{PM}_{2.5}\right)$ is $33 \%$ higher. Finally, EF for HONO, glycolaldehyde, and acetol are not found in AM2001 and they are now seen to be "major" emissions (EFs of 0.20, 0.81, and $0.45 \mathrm{~g} \mathrm{~kg}^{-1}$, respectively).
The underlying causes of all the differences depicted in Fig. 1 cannot be discussed in detail here, but they can be gleaned from the original papers and consideration of the various averaging schemes. However, for one category, much of the difference with AM2001 can be summarized succinctly, which we do next. Our extratropical smoldering compounds are generally higher than AM2001, which is mostly due to two factors. (1) Our total EFs for boreal fires reflect the large component of smoldering combustion in this region and are calculated by equally weighting the ground-based and airborne averages. (2) We also weight the boreal forest fire EFs more than the temperate forest fire EFs $(87: 13$, based on relative global fuel consumption) to generate our extratropical EF. Conversely, our $\mathrm{EF}\left(\mathrm{NO}_{\mathrm{x}}\right)$ for extratropical forest fires is about three times lower than $\mathrm{EF}\left(\mathrm{NO}_{\mathrm{x}}\right)$ for extratropical fires in $\mathrm{AM} 2001$. This is because the $\mathrm{EF}\left(\mathrm{NO}_{\mathrm{x}}\right)$ for temperate fires is higher than for boreal fires, but the temperate forest fire contribution is minimized in our extratropical average by our weighting scheme. However, our temperate forest fire $\mathrm{EF}\left(\mathrm{NO}_{\mathrm{x}}\right)$ is similar to the AM2001 $\mathrm{EF}\left(\mathrm{NO}_{\mathrm{x}}\right)$ for extratropical fires. For crop residue fires, the comparison to AM2001 is complex. The original AM2001 EFs relied on very limited data and extrapolations and AM2001 use a different averaging scheme than that applied in this work. In fact, we recommend using the EF measured specifically for mechanized or manual-harvest agriculture explicitly when possible (Sect. 2.3.13).

In comparison to Yevich and Logan (2003), the main difference is that they reported five major emitted species $\left(\mathrm{CO}_{2}\right.$, $\mathrm{CO}, \mathrm{CH}_{4}, \mathrm{NO}_{\mathrm{x}}$, and $\mathrm{PM}$ ) whereas we include many more species (nearly all recently-measured) in this work. For species reported in both compilations most of the values are within $40 \%$ of each other, but a few changed by a factor of 2 or more. Ratios of this work to Yevich and Logan (2003) for a given $\mathrm{EF}$ are shown in parentheses. The large changes are: lower $\mathrm{NO}_{\mathrm{x}}$ from charcoal burning (0.17) and dung burning (0.10); higher $\mathrm{CH}_{4}$ (4.07) and PM (18.8) from dung burning; and higher $\mathrm{CO}, \mathrm{CH}_{4}$, and $\mathrm{NO}_{\mathrm{x}}$ emissions from crop residue burned in field $(2.00,2.65$, and 2.79 , respectively). For the main type of biofuel burning (open wood cooking fires) the Yevich and Logan (2003) EFs are mostly very close to our EFs and all their EFs are within $48 \%$ of our updated values.

\subsection{Estimating unmeasured emission factors}

In general, estimating unmeasured values can improve model performance although this is not a guaranteed outcome. Our compilation does not tabulate estimates for unmeasured, individual species because the best estimation method depends on the application. The simplest estimates are obtained by using the EF values that may be available for the most similar fuel type. For example, filling in with $\mathrm{EF}$ values from one forest type for another, or using savanna fire EFs to estimate missing EFs for mechanized agriculture crop residue fires. To account for MCE differences between fire types, 

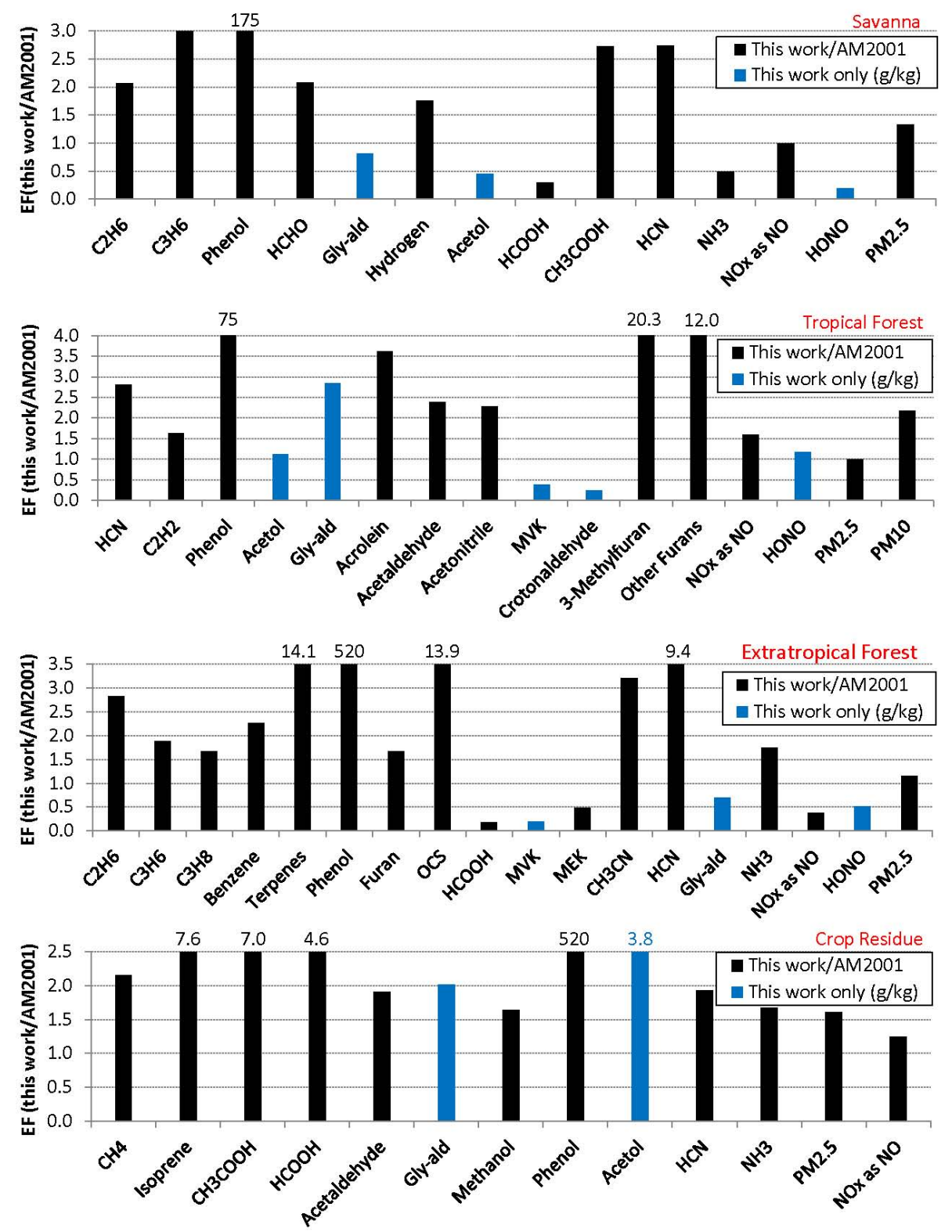

Fig. 1. The black columns show the EF in this work divided by the EF in Andreae and Merlet (2001) for the indicated species. The blue columns show the EF in $\mathrm{g} \mathrm{kg}^{-1}$ for species not found in Andreae and Merlet (2001). "Gly-ald", "MVK", and "MEK" indicate glycolaldehyde, methyl vinyl ketone, and methyl ethyl ketone, respectively. See Sect. 3.1 for discussion.

one can calculate missing EFs at the average MCE for a fire type using the relationships between EF and MCE for a similar fuel type. Or one can use the inter-compound ratios from the most similar fuel type. For example, assume compounds $\mathrm{X}$ and $\mathrm{Y}$ have both been measured for fuel type A, but only compound $\mathrm{X}$ has been measured for a similar fuel type $\mathrm{B}$. The emissions of compound $\mathrm{Y}$ from fuel type $\mathrm{B}$ can be estimated from: $\mathrm{Y}_{\mathrm{B}}=(\mathrm{Y} / \mathrm{X})_{\mathrm{A}} \times \mathrm{X}_{\mathrm{B}}$. If laboratory data is used it is critical to consider how realistic the fire simulations were. In addition, lab EFs may require some mathematical processing to project EF that better reflect field burning conditions.
These latter two issues are discussed in detail in Christian et al. (2003) and Yokelson et al. (2008). Another general principle is to use data relying on the most appropriate measurement technique available. For instance, in complex mixtures featuring sticky gases, some techniques may be more prone to chemical interference or positive or negative sampling artifacts. It is best to use sources where the smoke age and MCE are available in addition to the EF for the species of interest. Finally, if possible, estimates should be obtained from studies where the data for all the reported species seems reasonable. For example, BC values would be preferred from 
a study where all the trace gas EFs, particle size distributions, etc. are in the normal range as this indicates overall representative sampling. Sometimes a study may report a useful upper limit for a compound even though it does not report an EF. For instance, an upper limit is reported for glyoxal/acetone of $20 \%$ in OP-FTIR studies (Christian et al., 2003) or $10 \%$ in on-line, pre-separation MS studies (Karl et al., 2007; Warneke et al., 2011). In some cases, inspection of mass spectra can put an upper limit on the emissions of a compound, but it is frequently the case at high masses that many species appear at one nominal mass. Our estimates of total NMOC in Sect. 3.4 also provide very rough guidance for the sum of the compounds that are unmeasured.

\subsection{Specific compounds}

\subsubsection{HONO}

Given the abundance of highly reactive species present in fresh smoke, $\mathrm{OH}$ plays a key role in the "fast chemistry" of young plumes (Hobbs et al., 2003). Photolysis is the primary daytime fate of nitrous acid (HONO), which forms $\mathrm{OH}$ and NO with unit quantum yield within 10-20 min (Sander et al., 2006). Thus, HONO can be an important source of the $\mathrm{OH}$ radical, which then initiates attack on NMOCs (FinlaysonPitts and Pitts, 2000). Significant, direct emissions of gasphase HONO from $\mathrm{BB}$ at $\sim 3 \%$ of $\mathrm{NO}_{\mathrm{x}}$ was first reported for a savanna fire by Trentmann et al. (2005). A range of $\Delta \mathrm{HONO} / \Delta \mathrm{NO}_{\mathrm{x}}(5-30 \%)$ was then observed in a laboratory experiment burning various types of southern African biomass (Keene et al., 2006). A comparable molar ratio of $\Delta \mathrm{HONO} / \Delta \mathrm{NO}_{\mathrm{x}}(\sim 14 \%)$ was observed by Yokelson et al. (2007a) from a pasture fire in the Amazon (Table S12). The Caltech chemical ionization mass spectrometer (CIMS) measured similar HONO/NO ${ }_{\mathrm{x}}$ ER for Yucatan BB (Yokelson et al., 2009). OP-FTIR and the NOAA negative ion proton transfer CIMS were in good agreement with each other and observed $\mathrm{HONO} / \mathrm{NO}_{\mathrm{x}}$ ratios similar to those mentioned above when sampling laboratory fires burning North American biomass fuels (Roberts et al., 2010; Burling et al., 2010; Veres et al., 2010). A subsequent aircraft field campaign confirmed the lab $\mathrm{HONO} / \mathrm{NO}_{\mathrm{x}}$ ratios by airborne FTIR (Burling et al., 2011) for the same fuel types on open fires and also documented rapid post-emission HONO loss (Akagi et al., 2011). Similar $\mathrm{HONO} / \mathrm{NO}_{\mathrm{x}}$ ER were observed for boreal forest fires during ARCTAS (J. M. St. Clair, personal communication, 2010). The collective range of $\sim 3-30 \%$ in the ER $\triangle \mathrm{HONO} / \triangle \mathrm{NO}_{\mathrm{x}}$ from all studies suggests that HONO emissions may be highly dependent on fuel type (Keene et al., 2006; Burling et al., 2010). High levels of $\mathrm{OH}$ in young BB plumes that are consistent with photolysis of significant amounts of HONO have been observed at least twice (Hobbs et al., 2003; Yokelson et al., 2009) (discussed further in Sect. 3.5). In two prognostic model applications both Trentmann et al. (2005) and Alvarado and Prinn (2009) found that adding both a "reasonable" amount of initial HONO and a continuous source from heterogeneous chemistry to detailed photochemical models of BB plumes improved the agreement between simulated and observed ozone formation.

\subsubsection{HCN}

Andreae and Merlet (2001) reported HCN emission factors only from Hurst et al. (1994a, b) and stressed the need for more measurements of this species given its potential value as a biomass burning tracer ( $\mathrm{Li}$ et al., 2000). Within the past decade $\mathrm{EF}(\mathrm{HCN})$ has been measured frequently and the results have high variability. However, the bulk of the new data suggest average EF for most types of biomass burning that are about ten times higher than obtained in the first measurements (Tables 1 and 2). HCN has also proved useful as a tracer to deconvolute mixtures of urban and BB emissions (Yokelson et al., 2007b; Crounse et al., 2009). Currently there appears to be two main limitations in the use of $\mathrm{HCN}$ as a BB tracer. First, there is a high natural variability in $\mathrm{HCN}$ emissions even within a single or similar fire types. For example, Yokelson et al. (2009) note that the ER $\Delta \mathrm{HCN} / \triangle \mathrm{CO}$ for Brazilian tropical evergreen forest deforestation fires $(0.0063 \pm 0.0054)$ does not differ significantly from that of tropical dry forest deforestation fires in the Yucatan $(0.0066 \pm 0.0041)$. While it is encouraging that the mean, observed ER for these two fuel types are similar, the $1 \sigma$ standard deviation uncertainty in the mean is greater than $60 \%$ of the mean for both fuel types, which then contributes large uncertainty to $\mathrm{HCN}$-based estimates of the BB contribution to regional pollutant levels as discussed elsewhere (Yokelson et al., 2007b; Crounse et al., 2009). Second, there is a large difference in the $\Delta \mathrm{HCN} / \triangle \mathrm{CO}$ ER that can occur for some different fire types, which impacts estimates in the many areas featuring many types of biomass burning. For example, Christian et al. (2010) note that HCN levels fell below FTIR detection limits when sampling cooking fire emissions in both Mexico and Africa. Thus, more sensitive measurements of biofuel sources are needed for this fire type. On the other hand the $\mathrm{EF}(\mathrm{HCN})$ measured for peat fires appear to be about ten times larger than for other types of open burning (Tables 1, 2, and S5). Indonesia, as one example, can have large amounts of peat fires, forest fires, and biofuel use, complicating the use of $\mathrm{HCN}$ as a tracer in that region.

\subsection{3 $\mathrm{CH}_{3} \mathrm{CN}$}

Biomass burning is thought to be the primary source of acetonitrile in the atmosphere (de Gouw et al., 2003). Its relatively long lifetime (5-6 months, Li et al., 2003) and near exclusive production from biomass burning suggests great potential as a biomass burning tracer. Many groups have now measured $\mathrm{CH}_{3} \mathrm{CN}$ in smoke plumes by MS (Andreae et al., 2001; Jost et al., 2003; Holzinger et al., 1999; Karl et al., 2003, 2007; Christian et al., 2003; Yokelson et al., 2007a, 2009; Crounse et al., 2009). The $\Delta \mathrm{CH}_{3} \mathrm{CN} / \Delta \mathrm{HCN}$ ER has 
been shown to be quite robust in both laboratory and field measurements with molar ER of $0.39-0.56$ being observed for a wide range of non-boreal fuel types burned (Crounse et al., 2009; Yokelson et al., 2008, 2009; Christian et al., 2003). The $\Delta \mathrm{CH}_{3} \mathrm{CN} / \Delta \mathrm{HCN}$ ER for 4 boreal plumes sampled during ARCTAS was $0.30 \pm 0.11$ (Simpson et al., 2011). Analogous to $\mathrm{HCN}, \mathrm{CH}_{3} \mathrm{CN}$ is both unmeasured for cooking fires and was produced at order of magnitude higher levels by peat fires (Table S5).

\subsection{Gas-phase non-methane organic compounds (NMOC)}

Most NMOC are reactive so it is important to speciate as many as possible and to know the total amount. Early attempts to measure total gas-phase NMOC from $\mathrm{BB}$ relied on instruments designed to measure total NMHC (TNMHC, e.g. Cofer III. et al., 1993) and returned ER for $\Delta \mathrm{TNMHC} / \Delta \mathrm{CO}$ on the order of $24 \%$. However, it is now known that $\sim 60$ $80 \%$ of the NMOC emitted by BB are OVOC on a molar basis and that TNMHC instruments have a response to oxygenated compounds that is poorly characterized (Kállai et al., 2003). More recent attempts to estimate total NMOC are described next. PTR-MS is a "soft ionization" technique for measuring gas-phase NMOC with proton affinity higher than water (most NMOC) that produces essentially one peak per molecular mass and for which the proportionality between signal level and concentration falls within a narrow range for all compounds detected at each mass (Lindinger et al., 1998; Karl et al., 2007). GC and FTIR techniques can be useful for species identification when more than one compound appears at a mass, but their response factors to individual species vary over a greater range than for PTR-MS. In addition, many of the NMOC emitted by BB are too "sticky" or reactive to be measured by GC while FTIR works best for smaller molecules whose strongest absorption features are not severely overlapped by water or other co-emitted species (Goode et al., 1999). In BB studies that synthesized all three techniques the amount of MS signal due to identified and un-identified peaks was compared in a few selected "typical" PTR-MS mass spectra. In this way both Christian et al. (2003) and Karl et al. (2007) estimated that $72 \%$ of the NMOC in fresh smoke could be identified (on a molar basis) when considering all $\mathrm{m} / \mathrm{z}$ up to 205 . Since most of the unidentified species are heavier in mass $(>100 \mathrm{amu})$ this corresponds to successful identification of about $50 \%$ of the NMOC on a mass basis. In a recent laboratory-based fire study, additional advanced species identification processes were employed, but the unidentified species still ranged from $25-51 \%$ on a mass basis (Warneke et al., 2011).

Two major concerns regarding this large amount of unidentified (and often overlooked) NMOC species are (1) the additional reactivity they contribute to plume gasphase chemistry should be recognized in models, and (2) because of their high mass, on average, many are likely to be SVOC that could also condense after cooling or oxidation (Robinson et al., 2007). Consistent with the first effect, Trentmann et al. (2005) showed that tripling the $\mathrm{NMOC} / \mathrm{NO}_{\mathrm{x}}$ ratio above the measured amount improved model-measurement agreement for ozone. Alvarado and Prinn (2009) added monoterpenes to the BB initial emissions in their smoke model to increase the total organic gas-phase emissions by $30 \%$ as a surrogate for unidentified NMOC and this enabled their model to better reproduce the secondary formation of particulate organic carbon observed in a plume. Both findings suggest that model simulations can be improved by including NMOC that have not been identified to date.

Because unidentified NMOC emissions are both abundant and important, we have included their estimated EF for each fire type in Tables S1-S14 and in Tables 1 and 2 as described above. In addition, we provide a new global estimate of total NMOC emissions in Table 5, which supersedes the estimate in Table 5 of Yokelson et al. (2008). For most fuel types we calculated total identified NMOC by summing the individual average NMOC emission factors reported in Tables S1S14. We then estimated the potential total NMOC (identified plus unidentified) in $\mathrm{g} \mathrm{kg}^{-1}$ for each fire type by multiplying identified NMOC by a factor of 2 or 3 as needed. Based on the findings of Christian et al. (2003) and Karl et al. (2007) that only about half of the NMOC mass can be identified when the emissions are measured by FTIR, GC, and PTRMS, we employed a factor of 2 to estimate total NMOC from fire types where the emissions were measured with all these instruments. Yokelson et al. (2009) found that studies using 2 of these techniques identified only about $40 \%$ as much NMOC by mass compared to studies using all three techniques. Therefore, we use a factor of 3 to calculate potential total NMOC for those fire types that have so far only been sampled with minimal instrumentation (e.g. biofuel burning).

To scale to global production of gas-phase NMOC in $\mathrm{Tg} \mathrm{yr}^{-1}$ in Table 5, we multiply the total NMOC in $\mathrm{g} \mathrm{kg}^{-1}$ for each fire type by the estimated biomass consumption for that fire type from Table 4. Global production of NMOC from biofuels is calculated using $\mathrm{EF}(\mathrm{NMOC})$ of open cooking fires, since these types of fires are the dominant source of biofuel emissions on a global scale (Dherani et al., 2008). Summing the annual gas-phase NMOC from each fire type results in a total BB gas-phase NMOC source of $406 \mathrm{Tg} \mathrm{yr}^{-1}$ ( $383 \mathrm{Tg} \mathrm{yr}^{-1}$ without garbage burning). We then show that adding the estimated NMOC emissions from peat fires in the $1997 \mathrm{El}$ Niño year brings the global total to $737 \mathrm{Tg} \mathrm{yr}^{-1}$. The latter estimate is an upper limit for emissions during an El Niño year when a large number of fires affected the Indonesian tropical peatlands. The lower value of $383 \mathrm{Tg} \mathrm{yr}^{-1}$ ignores the contribution from peat and garbage burning entirely. We note that Table 2 of AM2001 estimates that about $100 \mathrm{Tg} \mathrm{yr}^{-1}$ of identified NMOC are emitted by BB when considering all the NMHC and several of the main OVOC. If the other OVOC from their Table 1 (that are not 
Table 5. Measured and predicted estimates of NMOC emitted from biomass burning on an annual basis.

\begin{tabular}{|c|c|c|c|c|c|c|c|c|}
\hline Fuel Type & $\begin{array}{l}\text { Total } \\
\text { Combusted } \\
\text { Biomass } \\
\left(\mathrm{Tg} \mathrm{yr}^{-1}\right)^{\mathrm{a}}\end{array}$ & 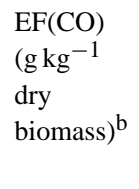 & $\begin{array}{l}\text { CO global } \\
\text { production } \\
\left(\mathrm{Tg} \mathrm{yr}^{-1}\right)\end{array}$ & 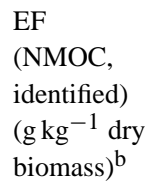 & 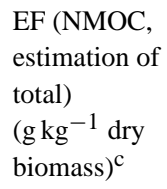 & $\begin{array}{l}\text { NMOC } \\
\text { global } \\
\text { production } \\
\left(\operatorname{Tg~yr}^{-1}\right)\end{array}$ & $\begin{array}{l}\mathrm{EF}(\mathrm{BC}) \\
\left(\mathrm{g} \mathrm{kg}^{-1} \text { dry }\right. \\
\text { biomass })\end{array}$ & $\begin{array}{l}\text { BC global } \\
\text { production } \\
\left(\mathrm{Tg} \mathrm{yr}^{-1}\right)\end{array}$ \\
\hline Savanna & 3366 & 63 & 212 & 12.4 & 24.7 & 83 & 0.37 & 1.25 \\
\hline Extratropical & 640 & 122 & 78 & 27.0 & 54.0 & 35 & 0.56 & 0.36 \\
\hline Open Cooking/Cooking Stoves & 1351 & 59.5 & 80 & 10.5 & 31.6 & 42.7 & 0.79 & 1.06 \\
\hline Dung Burning & 106 & 105 & 11.1 & 32.6 & 97.7 & 10.4 & 0.53 & 0.056 \\
\hline Charcoal Making & 43 & 255 & 11.0 & 161 & 321 & 13.8 & 0.02 & $8.6 \times 10^{-4}$ \\
\hline Charcoal Burning & 39 & 189 & 7.4 & 5.56 & 11.1 & 0.43 & 1.0 & 0.039 \\
\hline Pasture Maintenance & 240 & 135 & 32 & 44.8 & 89.6 & 21.5 & 0.91 & 0.22 \\
\hline Crop Residue & 489 & 102 & 50 & 25.7 & 51.4 & 25.1 & 0.75 & 0.367 \\
\hline
\end{tabular}

a Total combusted biomass estimates are from Table 4 averages (this work), unless otherwise noted. Charcoal making estimate is in units of Tg charcoal made per year. Charcoal burning estimate is in units of $\mathrm{Tg}$ charcoal burned per year.

b Data are from Tables 1 and 2 of this work. EF for open cooking fires was used to represent EF for all biofuel since cooking fires are the dominant source of biofuel emissions globally. EF for open cooking/cooking stoves was taken as the averages of open cooking and cooking stove EF. Charcoal making EF in units of $\mathrm{g} \mathrm{kg}^{-1}$ charcoal made. Charcoal burning $\mathrm{EF}$ in units of $\mathrm{g} \mathrm{kg}^{-1}$ charcoal burned.

${ }^{\mathrm{c}}$ Multiplication factors to estimate total EF(NMOC) (as identified + unidentified NMOC) is described in Sect. 3.4.

${ }^{\mathrm{d}}$ Emissions from peat are added to global totals to estimate a typical emissions during an El Niño year.

included in their Table 2) are considered, it suggests that about $150 \mathrm{Tg} \mathrm{yr}^{-1}$ of identified NMOC are emitted by BB globally. Doubling this value to account for unidentified species suggests a true global total near $300 \mathrm{Tg} \mathrm{yr}^{-1}$, however, this has not been widely realized. The latter value is only $20-30 \%$ lower than our estimate in Table 5. Clearly biomass burning emissions of NMOC rank well ahead of urban NMOC emissions globally and are second only to biogenic emissions $\left(\sim 1000 \mathrm{Tg} \mathrm{yr}^{-1}\right)$ as discussed in Yokelson et al. (2008). CO and black carbon (BC) are also important BB emissions. Both as a demonstration of (and a check on) our methodology in Table 5, we also combine our biomass consumption values with the measured $\mathrm{EF}(\mathrm{CO})$ and $\mathrm{EF}(\mathrm{BC})$ for each fire type to produce global $\mathrm{BB}$ central estimates for $\mathrm{CO}$ $\left(734 \mathrm{Tg} \mathrm{yr}^{-1}\right)$ and $\mathrm{BC}\left(5.69 \mathrm{Tg} \mathrm{yr}^{-1}\right)$ that are in good agreement with other recent estimates (Kopacz et al., 2010; Bond et al., 2004).

\subsection{Post emission processing}

The emission factors presented herein were calculated from fresh smoke sampled at the source that had usually cooled to ambient temperature, but undergone minimal photochemical aging. In nearly any application of this data, it is important to realize that rapid, complex photochemistry can cause large changes in smoke composition within minutes after its initial emission. There is a not a single standard process- ing scenario that can be applied to all smoke. Rather, there are numerous possible fates of smoke given differences in initial emissions, degree of cloud processing, dispersion altitude, temperature, humidity, time of day or night, small vs. large-scale fires (e.g. cooking fires vs. forest fires), the degree of mixing with other $\mathrm{BB}$ plumes or biogenic or urban emissions, etc. In theory, almost any realistic processing scenario can be modeled. In practice, very few detailed smoke evolution data have been acquired that are of value for testing or constraining the chemical mechanism in smoke photochemistry models. Next we summarize the measurements that have been made and draw a few conclusions.

The type of measurements that provide the most straightforward test of photochemical models are those that trace the evolution of a single, isolated BB plume. Measurements of this type have been obtained in Alaska, Africa, California, Mexico, and Canada. Goode at al. (2000) sampled two very large plumes up to $\sim 56 \mathrm{~km}$ downwind in Alaska (their Table 6). The B280 fire plume was sampled well below the top of the plume and no ozone formation or change in a reactive hydrocarbon $\left(\mathrm{C}_{2} \mathrm{H}_{4}\right)$ was observed over $\sim 2.8 \mathrm{~h}$ of aging. However $\mathrm{NH}_{3}$ decreased about $70 \%$ over that time. The B309 fire plume was sampled closer to the top and within $\sim 2 \mathrm{~h}$ of aging the $\Delta \mathrm{O}_{3} / \Delta \mathrm{CO}$ ratio had risen to $\sim 9 \%$ (from negative values at initial injection). Both $\Delta \mathrm{HCOOH} / \Delta \mathrm{CO}$ and $\Delta \mathrm{CH}_{3} \mathrm{COOH} / \Delta \mathrm{CO}$ doubled on that time scale, but the decrease in $\mathrm{C}_{2} \mathrm{H}_{4}$, which would have 
accompanied high $\mathrm{OH}$, was small enough to be insignificant. The chemical evolution of five different isolated BB plumes was tracked by various aircraft during the Southern Africa Fire Atmosphere Research Initiative (SAFARI) 2000. Three of these plumes were sampled by the University of Washington Convair 580 (Fig. 5 in Yokelson et al., 2003 ) and $\Delta \mathrm{O}_{3} / \Delta \mathrm{CO}$ rose to $\sim 9 \%$ in only $\sim 40 \mathrm{~min}$ of aging. In addition $\Delta \mathrm{CH}_{3} \mathrm{COOH} / \Delta \mathrm{CO}$ more than tripled from its initial value to $\sim 9 \%$ within the same aging interval. Additional detailed analysis of the most extensively sampled plume (Hobbs et al., 2003), the Timbavati plume, revealed a rapid loss of $\mathrm{NO}_{\mathrm{x}}$ and 16 reactive hydrocarbons consistent with an average $\mathrm{OH}$ of $1.7 \times 10^{7}$ molecules $\mathrm{cm}^{-3}$. Technical issues involving the sampling system preclude us from making conclusive quantitative statements about the evolution of the particles in that plume (Alvarado and Prinn, 2009; Magi, 2009), but particle nitrate definitely increased and OC likely did also. Jost et al. (2003) sampled a Namibian BB plume at 11 different smoke ages and observed $\Delta \mathrm{O}_{3} / \Delta \mathrm{CO}$ rise to $\sim 10 \%$ in $\sim 2 \mathrm{~h}$ and also a tendency for acetone to be enhanced in the downwind plume. In another African plume, Abel et al. (2003) measured an increase in single scattering albedo from 0.84 to 0.885 over $2.4 \mathrm{~h}$ of aging that they attributed to condensation of non-absorbing (organic) species.

Yokelson et al. (2009) described the evolution during $1.5 \mathrm{~h}$ of aging of a single BB plume in the Yucatan sampled by the NCAR C-130. $\Delta \mathrm{O}_{3} / \Delta C O$ rose to $10-15 \%$ in about one hour, which is almost identical to the $\mathrm{O}_{3}$ formation rate observed by Hobbs et al. (2003). Rapid secondary production of peroxyacetylnitrate (PAN), hydrogen peroxide, formic acid, and peroxyacetic acid was observed. The post emission loss rates were measured for $\mathrm{SO}_{2}, \mathrm{NO}_{\mathrm{x}}$, and HONO. No reactive NMOC were measured in the down-wind plume, but in-plume $\mathrm{OH}$ was directly measured for the first time in a BB plume and averaged $1.14 \times 10^{7}$ molecules $\mathrm{cm}^{-3}$ for the plume age interval 22-43 min. Significant post-emission formation rates for particle nitrate, ammonium, sulfate, organic aerosol (OA), and an increase in single scattering albedo were measured. Aerosol mass spectrometry and light scattering measurements both indicated that the aerosol to $\mathrm{CO}$ ratio increased by a factor of $\sim 2.4$ in $1.5 \mathrm{~h}$. In another isolated Yucatan plume TEM analysis indicated that slightly aged smoke had a higher abundance of tar balls (Yokelson et al., 2009), which have been linked to the concept of brown carbon (Adachi and Buseck, 2008; Andreae and Gelenesér, 2006; Chakrabarty et al., 2010). Recently the evolution of an isolated BB plume was measured in mid-coast California for $\sim 4.5 \mathrm{~h}$. A rapid increase in light scattering and formation of $\mathrm{O}_{3}, \mathrm{HCOOH}, \mathrm{CH}_{3} \mathrm{COOH}$, and PAN was observed along with loss of $\mathrm{NO}_{\mathrm{x}}, \mathrm{HONO}, \mathrm{C}_{2} \mathrm{H}_{4}, \mathrm{C}_{3} \mathrm{H}_{6}$, and $\mathrm{NH}_{3}$ (Akagi et al., 2011).

The chemical evolution of one boreal forest fire plume (Flight 18, McKay Lake Fire) was extensively measured during ARCTAS (Alvarado et al., 2010). This fire plume exhibited two different types of behavior on the same day.
In particular, the early evening samples were divided into two groups: those obtained below $1 \mathrm{~km}$ and those obtained above $2 \mathrm{~km}$. The low altitude samples had low MCE (more smoldering, 0.85-0.92) and low $\Delta \mathrm{NO}_{\mathrm{y}} / \Delta \mathrm{CO}(0.34-0.55 \%)$. After $\sim 4 \mathrm{~h}$ of aging $\Delta \mathrm{PAN} / \Delta \mathrm{CO}$ reached $0.23-0.36 \%$ and $\Delta \mathrm{O}_{3} / \Delta \mathrm{CO}$ ranged from $-1 \%$ to $3 \%$. The higher altitude samples had higher MCE (more flaming, 0.96) and a higher $\Delta \mathrm{NO}_{\mathrm{y}} / \Delta \mathrm{CO}(1.1-1.7 \%)$. In the high altitude samples (produced by more vigorous combustion) $\Delta \mathrm{PAN} / \Delta \mathrm{CO}$ reached $0.51 \%$ after only one hour, by which time $\Delta \mathrm{O}_{3} / \Delta \mathrm{CO}$ had already reached $5 \%$. These results nicely illustrate the high natural variability in post-emission processing that can be expected for fires, which was, in this case, driven partly by variable initial emissions. In light of the potential connection between plume chemistry and plume injection altitudes it is significant that large numbers of BB plume heights can now be measured from space about once per day (Val Martin et al., 2010). However, in the boreal forest, where individual fires can burn for weeks, the fire radiative energy (and likely the biomass consumption rate and injection altitude) may not peak at mid-day in a simple diurnal cycle. In fact, the regional fire radiative energy can be higher at night (see Fig. 4b of Vermote et al., 2009), which could be driven by frontal passage or other weather or fuel conditions.

Several authors have constructed detailed photochemical models for direct comparison to the measurements in some of the plumes mentioned above (Jost et al., 2003; Trentmann et al., 2005; Mason et al., 2006; Alvarado and Prinn, 2009; Alvarado et al., 2010). Taken together, these studies show that model performance is improved by considering the initial emissions of HONO, a continuous heterogeneous source of HONO, and unidentified NMOC. In addition, Alvarado et al. (2010) discuss application-specific techniques to improve model performance at larger geographic scales.

It is also useful to compare data acquired in "intercepted", aged plumes to "probable" initial values. Yokelson et al. (2009) discuss sources of uncertainty in interpretation of data from aged smoke only in their Sect. 3.5. The comparison is least uncertain for species which have tightly constrained initial values such as $\Delta \mathrm{O}_{3} / \Delta \mathrm{CO}$, which is negative in fresh plumes (Yokelson et al., 2003). For example, Andreae et al. (1994) described encounters with 40 different tropical BB plumes about 7-10 days old for which $\Delta \mathrm{O}_{3} / \Delta \mathrm{CO}$ averaged $43 \pm 26 \%$ (ranging from $11-89 \%$ ) and where $\Delta \mathrm{O}_{3} / \Delta \mathrm{CO}$ correlated positively with $\Delta \mathrm{NO}_{\mathrm{y}} / \Delta \mathrm{CO}$ (their Table 1 and Fig. 14). At the other end of the spectrum, 1-2 day old plumes from smoldering tundra fires in the Arctic had an average $\Delta \mathrm{O}_{3} / \Delta \mathrm{CO}$ of $9.5 \pm 6 \%$ (Wofsy et al., 1992; Jacob et al., 1992). The smaller $\mathrm{O}_{3}$ enhancements in the arctic plumes were attributed to younger plume age and a factor of ten lower initial $\Delta \mathrm{NO}_{\mathrm{x}} / \Delta \mathrm{CO}$ (inferred from lower $\Delta \mathrm{NO}_{\mathrm{y}} / \Delta \mathrm{CO}$ ) (Andreae et al., 1994). Nine plumes from boreal wildfires that were 6-15 days old were sampled at the PICO-NARE station in 2004 and eight of the plumes had $\Delta \mathrm{O}_{3} / \Delta \mathrm{CO}$ ranging from $9 \%$ to $89 \%$ (Table 3 
of Val Martín et al., 2006; Lapina et al., 2006). However one aged plume had $\Delta \mathrm{O}_{3} / \Delta \mathrm{CO}$ of $-42 \%$ (vide infra). Higher $\mathrm{O}_{3}$ enhancements were correlated with higher $\mathrm{NO}_{\mathrm{y}}$. Yokelson et al. (2007a) sampled a large regional plume in Brazil containing the mixed output from many regional fires with smoke age likely ranging from $1-20 \mathrm{~h}$ that had enhanced $\mathrm{O}_{3}, \mathrm{HCOOH}$, and $\mathrm{CH}_{3} \mathrm{COOH}$. Reid et al. (1998) compared regional haze dominated by aged $\mathrm{BB}$ smoke to $\mathrm{BB}$ smoke $<4$ min old in Brazil. Smoke aging was associated with loss of gas-phase NMHC and growth of particle ammonium, organic acids, and sulfate as well as other changes including increases in particle size and single scattering albedo.

The observation at PICO-NARE that some plumes may have little or no photochemical activity is consistent with some airborne observations. One of two Alaskan plumes traced by Goode et al. (2000) and several aged plumes encountered at high altitude off the coast of the US by de Gouw et al. (2006) or in Africa by Capes et al. (2009) showed little evidence of oxidation. Most of the boreal forest fire plumes sampled during ARCTAS were photochemically active enough to generate substantial amounts of PAN, but very little $\mathrm{O}_{3}$ (Alvarado et al., 2010; Singh et al., 2010). A variety of plume chemistry regimes has been observed in remote sensing studies. For example, Fishman et al. (1991) attributed widespread $\mathrm{O}_{3}$ enhancements in the Southern Hemisphere to BB, while Verma et al. (2009) observed both $\mathrm{O}_{3}$ formation and $\mathrm{O}_{3}$ destruction in boreal forest fire plumes. In summary, the airborne, ground-based, and space-based observations consistently demonstrate that a large range in post-emission outcomes is possible. An important aspect of this variability is that despite the difficulty of using reactive initial emissions as input for regional-global models, there may not be an advanced smoke age that provides significant advantages as a starting point at which emissions could be tabulated.

A few observations have been made of cloud processing of smoke. Yokelson et al. (2003) observed rapid reduction in $\mathrm{NO}, \mathrm{CH}_{3} \mathrm{OH}, \mathrm{NH}_{3}$, and $\mathrm{CH}_{3} \mathrm{COOH}$ and concurrent fast $\mathrm{NO}_{2}$ and $\mathrm{HCHO}$ formation within a small pyrocumulus cloud that capped a vertical column of smoke $\sim 3 \mathrm{~km}$ above the flame front. This was modeled as the product of heterogeneous reactions of $\mathrm{CH}_{3} \mathrm{OH}$ on droplet surfaces combined with enhanced photochemistry in the cloud (Tabazadeh et al., 2004; Madronich, 1987). Unpublished data from the Yucatan plume described earlier in this section shows a very large step increase in $\triangle \mathrm{HCHO} / \triangle \mathrm{CO}$ immediately after the plume $\mathrm{RH}$ briefly exceeded $100 \%$, a potential sign of cloud-processing (A. Fried and T. Campos, personal communication, 2010). A large fraction of the smoke on Earth resides in hazy boundary layers that are "topped" with a layer of embedded cumulus clouds. These clouds also play a role in "pumping" smoke from the boundary layer to the free troposphere. For these reasons, smoke-cloud interactions require much more research.

\subsection{Knowledge gaps and sources of uncertainty}

\subsubsection{Poorly characterized combustion/fire types and post-emission processing scenarios}

The emissions from residual smoldering combustion have rarely been measured and measurements of fuel consumption by RSC are also rare. This is a major source of uncertainty for every type of open burning except grass fires. For instance, Bertschi et al. (2003b) showed that if RSC accounted for $10 \%$ of fuel consumption on woody savanna fires, the fire-average EF for some species would be $\sim 2.5$ times larger. Biofuel use (e.g. cooking fires) is the second largest type of global BB, but often overlooked as these small fires elude satellite detection. Biofuel consumption is estimated from questionnaires distributed in rural areas (Yevich and Logan, 2003), which may underestimate urban and industrial biofuel use. The NMOC emissions from biofuel use have not been measured with mass spectrometry, which is required for comprehensive smoke analysis. Thus, $\mathrm{HCN}$ and $\mathrm{CH}_{3} \mathrm{CN}$ emissions have not been quantified for biofuels and there is no chemical tracer to validate survey results (Christian et al., 2010). The lack of a tracer to verify surveys is especially problematic for industrial biofuel use. Small informal firms account for over $50 \%$ of non-agricultural employment and 25-75\% of gross domestic product in both Latin America and Africa (Ranis and Stewart, 1994; Schneider and Enste, 2000). These firms use a variety of fuels (wood, sawdust, crop residue, coal, used motor oil, tires, garbage, boards with lead paint, etc.) and some are illegal, which can affect survey results (Christian et al., 2010). More biofuel measurements, with more complete instrumentation, are needed to characterize the diverse emissions, which depend on fuel, geography, local customs, climate, and season (Yevich and Logan, 2003).

Garbage burning (GB) is a poorly characterized emission source that can be significant in urban-rural areas of developing and developed nations. Christian et al. (2010) made seminal measurements of open GB. High $\mathrm{EF}(\mathrm{HCl})(1.65-$ $9.8 \mathrm{~g} \mathrm{~kg}^{-1}$ ) traceable to waste polyvinyl chloride suggest that GB is the main global source of $\mathrm{HCl}$. GB emits large amounts of $\mathrm{PM}, \mathrm{HCl}$, and $\mathrm{NO}_{\mathrm{x}}$ (Yokelson et al., 2011) and interaction between these species could impact $\mathrm{O}_{3}$ formation (Osthoff et al., 2008; Raff et al., 2009; Thornton et al., 2010). GB is the main global source of dioxins (Costner, 2005, 2006) and the emissions of other toxic chlorinated compounds should be measured. GB could impact source apportionment studies because it emits high levels of several compounds used as tracers for BB such as levoglucosan (Christian et al., 2010).

Relatively few measurements have been made of BB in temperate regions where much of the burning is prescribed for land management, but controlled to protect air quality (Mutch, 1994; Neary et al., 2005; Wiedinmyer and Hurteau, 2010). Models often assess the air quality impacts using 
EFs from tropical and boreal forest fires, which adds uncertainty. Preliminary results from recent laboratory and field campaigns in temperate regions are included in this compilation. Finally, there are very few measurements of important post-emission processing scenarios such as nighttime smoke chemistry and mixing with clouds or other plumes.

\subsubsection{Measurement challenges}

The proper measurement of particle-phase light absorbing carbon (LAC, including BC, weak absorption by organic carbon (OC), and strong absorption by "brown carbon") and the best way to represent LAC in models is an area of active research (Andreae and Gelenesér, 2006; Magi, 2009; Chakrabarty et al., 2010). Most of the high molecular mass NMOC in both the gas and condensed phases are still unidentified, making it difficult to model their atmospheric impact. Moving from the current common mass resolution of $\sim 200$ to $\sim 5000$ and scanning at higher masses will allow more of these compounds to be identified. However, compounds with different structural formulas can have the same molecular mass at any resolution (e.g. acetic acid and glycolaldehyde) (Jordan et al., 2009). Species with identical mass can sometimes be quantified based on their different tendencies to form clusters, pre-separation, or MS-MS techniques, but all these approaches have limitations and many of the unknown species are semi-volatile and thus difficult to sample (Crounse et al., 2006; Karl et al., 2007). However, improved knowledge of the chemical formula of the emissions present at higher masses should enable an improved assessment of the physical properties of these emissions (e.g. vapor pressure, reactivity, etc.).

Limitations exist for all platforms used to study BB. Each offers well-documented advantages, but here we mention some key limitations and ideas for overcoming them. In laboratory studies many fire-types are hard to replicate and the different products of flaming and smoldering combustion may not mix the same way as in real fires. Wall losses limit aging studies to a few hours. Careful comparison/synthesis of laboratory results with field results for similar fuels (discussed at length in Yokelson et al., 2008) should maintain a key role for laboratory studies in future BB research.

Airborne studies sample real fires, but the lofted and unlofted emissions can have different chemistry and postemission transport. Simultaneous ground-based and airborne EF measurements have been made on the same fire (Yokelson et al., 2008), but more measurements of the biomass consumption contributing to the lofted and unlofted emissions are needed, as noted above. Airborne platforms can study aging on long time scales, but real world smoke is often a complex mixture of young and old plumes and non-BB sources. The use of multiple tracers helps deconvolute mixtures of urban and BB emissions (Crounse et al., 2009).
Remote sensing provides numerous products to drive and validate models, but the global loss of information due to cloud coverage and lack of daily coverage by MODIS in the tropics are serious limitations. Detection efficiency of fires as hot-spots or burn scars is poor for small fires, which may comprise the majority of tropical fires (Hawbaker et al., 2008; Chang and Song, 2010a; Giglio et al., 2006). Comparison of burned area or hotspot products often reveals factor of ten or larger disagreements (e.g. Al-Saadi et al., 2008; Tables 5-7 in Chang and Song, 2010a, b). The latter authors noted that GFED2.1-based estimates of CO emissions from tropical Asia were 5-7 times higher than their estimates based on MODIS or L3JRC burned area products. On the other hand, Kopacz et al. (2010) concluded that GFED2.1 significantly underestimated $\mathrm{CO}$ from biomass burning in this region and globally. Better characterization of remote sensing products could improve their incorporation into models and possibly inform the development of new sensors.

The most serious measurement limitations from the standpoint of model accuracy may be as follows. At the plume scale, there is a large fraction of unidentified, reactive NMOC and few measurements of plume aging that constrain/validate chemical mechanisms. At regional-global scales there is uncertainty in biomass consumption, plume injection heights, and model parameterizations for processes that occur on spatial scales much smaller than the model grid (Alvarado et al., 2009, 2010; Fast et al., 2009). Additional measurements and improvements in computing power and parameterization of fast processes could increase model performance (Alvarado et al., 2009, 2010).

\section{Conclusions}

In the past ten years significant progress has been made in characterizing the initial emissions of trace gases and particles from biomass burning and their post-emission evolution. New instruments better quantify particle species, useful BB tracers, and light oxygenated NMOC, which account for much of the gas-phase NMOC emitted by fires. The detailed chemical evolution of several individual BB plumes has now been measured in the field. This new information has improved model performance for several biomass burning fuel types. In this work, recent studies are used to derive emission factors that characterize the nascent emissions from 14 types of biomass burning. Biomass burning terminology, biomass consumption, and plume aging are also summarized. Large uncertainties still exist for fire types (e.g. biofuels) and smoke-processing scenarios (e.g. clouds, night-time) that have been sampled only minimally with currently available instruments. Thus, significant advances could be achieved in the near future by deploying existing technology more extensively and we plan to update the EF data as warranted. 


\section{Supplementary material related to this article is available online at: http://www.atmos-chem-phys.net/11/4039/2011/ acp-11-4039-2011-supplement.zip.}

Acknowledgements. We thank Isobel Simpson, Don Blake, Andy Weinheimer, Armin Wisthaler, Guido van der Werf, Thijs van Leeuwen, Ian Burling, Tami Bond, Christoph Roden, and Ted Christian for advance data. We thank Jennifer Logan, Ed Hyer, Jim Reardon, John Graham, Mark Carroll, Angelika Heil, and Ben Foster, for helpful discussions. SKA thanks Paulette Middleton and GEIA for financial support. Akagi and Yokelson were supported by NSF grants ATM-0513055 and ATM-0936321.

Edited by: C. Granier

\section{References}

Abel, S. J., Haywood, J. M., Highwood, E. J., Li, J., and Buseck, P. R.: Evolution of biomass burning aerosol properties from an agricultural fire in southern Africa, Geophys. Res. Lett., 30(15), 1783, doi:10.1029/2003GL017342, 2003.

Adachi, K. and Buseck, P. R.: Internally mixed soot, sulfates, and organic matter in aerosol particles from Mexico City, Atmos. Chem. Phys., 8, 6469-6481, doi:10.5194/acp-8-6469-2008, 2008.

Akagi, S. K., Craven, J. S., Taylor, J., McMeeking, G. R., Yokelson, R. J., Burling, I. R., Urbanski, S. P., Wold, C. E., Seinfeld, J. H., Coe, H., and Alvarado, M. J.: Evolution of trace gases and particles emitted by a chaparral fire in California, in preparation, 2011.

Al-Saadi, J., Soja, A., Pierce, R. B., Szykman, J., Wiedinmyer, C., Emmons, L., Kondragunta, S., Zhang, X., Kittaka, C., Schaack, T., and Bowman, K.: Evaluation of near-real-time biomass burning emissions estimates constrained by satellite fire data, J. Appl. Remote Sens., 2, 021504, doi:10.1117/1.2948785, 2008.

Alvarado, M. J. and Prinn, R. G.: Formation of ozone and growth of aerosols in young smoke plumes from biomass burning: 1. Lagrangian parcel studies, J. Geophys. Res., 114, D09306, doi:10.1029/2008JD011144, 2009.

Alvarado, M. J., Wang, C., and Prinn, R. G.: Formation of ozone and growth of aerosols in young smoke plumes from biomass burning: 2. Three-dimensional Eulerian studies, J. Geophys. Res., 114, D09307, doi:10.1029/2008JD011186, 2009.

Alvarado, M. J., Logan, J. A., Mao, J., Apel, E., Riemer, D., Blake, D., Cohen, R. C., Min, K.-E., Perring, A. E., Browne, E. C., Wooldridge, P. J., Diskin, G. S., Sachse, G. W., Fuelberg, H., Sessions, W. R., Harrigan, D. L., Huey, G., Liao, J., Case-Hanks, A., Jimenez, J. L., Cubison, M. J., Vay, S. A., Weinheimer, A. J., Knapp, D. J., Montzka, D. D., Flocke, F. M., Pollack, I. B., Wennberg, P. O., Kurten, A., Crounse, J., Clair, J. M. St., Wisthaler, A., Mikoviny, T., Yantosca, R. M., Carouge, C. C., and Le Sager, P.: Nitrogen oxides and PAN in plumes from boreal fires during ARCTAS-B and their impact on ozone: an integrated analysis of aircraft and satellite observations, Atmos. Chem. Phys., 10, 9739-9760, doi:10.5194/acp-10-9739-2010, 2010.
Andreae, M. O. and Gelencsér, A.: Black carbon or brown carbon? The nature of light-absorbing carbonaceous aerosols, Atmos. Chem. Phys., 6, 3131-3148, doi:10.5194/acp-6-3131-2006, 2006.

Andreae, M. O. and Merlet, P.: Emission of trace gases and aerosols from biomass burning, Global Biogeochem. Cy., 15(4), 955-966, doi:10.1029/2000GB001382, 2001.

Andreae, M. O., Browell, E. V., Garstang, M., Gregory, G. L., Harriss, R. C., Hill, G. F., Jacob, D. J., Pereira, M. C., Sachse, G. W., Setzer, A. W., Silva Dias, P. L., Talbot, R. W., Torres, A. L., and Wofsy, S. C.: Biomass burning emissions and associated haze layers over Amazonia, J. Geophys. Res., 93, 1509-1527, 1988.

Andreae, M. O., Anderson, B. E., Blake, D. R., Bradshaw, J. D., Collins, J. E., Gergory, G. L., Sachse, G. W., and Shipham, M. C.: Influence of plumes from biomass burning on atmospheric chemistry over the equatorial and tropical South Atlantic during CITE 3, J. Geophys Res., 99, 12793-12808, doi:10.1029/94JD00263, 1994.

Andreae, M. O., Artaxo, P., Fischer, H., Freitas, S. R., Grégoire, J.-M., Hansel, A., Hoor, P., Kormann, R., Krejci, R., Lange, L., Lelieveld, J., Lindinger, W., Longo, K., Peters, W., de Reus, M., Scheeren, B., Silva Dias, M. A. F., Ström, J., van Velthoven, P. F. J, and Williams, J.: Transport of biomass burning smoke to the upper troposphere by deep convection in the equatorial region, Geophys. Res. Lett., 28(6), 951-954, 2001.

Andreae, M. O., Rosenfeld, D., Artaxo, P., Costa, A. A., Frank, G. P., Longo, K. M., and Silva Dias, M. A. F.: Smoking rain clouds over the Amazon, Science, 303, 1337-1342, 2004.

Archibald, A. T., Cooke, M. C., Utembe, S. R., Shallcross, D. E., Derwent, R. G., and Jenkin, M. E.: Impacts of mechanistic changes on $\mathrm{HO}_{\mathrm{x}}$ formation and recycling in the oxidation of isoprene, Atmos. Chem. Phys., 10, 8097-8118, doi:10.5194/acp10-8097-2010, 2010.

Artaxo, P., Fernandes, E. T., Martins, J. V., Yamasoe, M. A., Hobbs, P. V., Maenhaut, W., Longo, K. M., and Castanho, A.: Largescale aerosol source apportionment in Amazonia, J. Geophys. Res., 103, 31837-31847, 1998.

Babbitt, R. E., Ward, D. E., Susott, R. A., Artaxo, P., and Kauffman, J. B.: A comparison of concurrent airborne and ground-based emissions generated from biomass burning in the Amazon Basin, SCAR-B Proceedings, Transtec, Saõ Paulo, Brazil, 1996.

Ballhorn, U., Siegert, F., Mason, M., and Limin, S.: Derivation of burn scar depths and estimation of carbon emissions with LIDAR in Indonesian peatlands, PNAS, 106(50), 21213-21218, 2009.

Barbosa, R. I. and Fearnside, P. M.: Pasture burning in Amazonia: Dynamics of residual biomass and the storage and release of aboveground carbon, J. Geophys. Res., 101(D20), 25847-25857, 1996.

Bertschi, I. T., Yokelson, R. J., Ward, D. E., Christian, T. J., and Hao, W. M.: Trace gas emissions from the production and use of domestic biofuels in Zambia measured by open-path Fourier transform infrared spectroscopy, J. Geophys. Res., 108(D13), 8469, doi:10.1029/2002JD002158, 2003a.

Bertschi, I. T., Yokelson, R. J., Ward, D. E., Babbitt, R. E., Susott, R. A., Goode, J. G., and Hao, W. M.: Trace gas and particle emissions from fires in large diameter and belowground biomass fuels, J. Geophys. Res., 108(D13), 8472, doi:10.1029/2002JD002100, 2003b.

Bond, T. C. and Bergstrom, R. W.: Light absorption by 
carbonaceous particles: An investigative review, Aerosol Sci. Tech., 40, 27-67, doi:10.1080/02786820500421521, 2006.

Bond, T. C., Streets, D. G., Yarber, K. F., Nelson, S. M., Woo, J.H., and Klimont, Z.: A technology-based global inventory of black and organic carbon emissions from combustion, J. Geophys. Res., 109, D14203, doi:10.1029/2003JD003697, 2004.

Brocard, D. and Lacaux, J. P.: Domestic biomass consumption and associated atmospheric emissions in West Africa, Global Biogeochem. Cy., 15(1), 127-139, 1998.

Brocard, D., Lacaux, C., Lacaux, J. P., Kouadio, G., and Yoboué, V.: Emissions from the combustion of biofuels in western Africa, in: Biomass Burning and Global Change, edited by: Levine, J. S., MIT Press, Cambridge, MA, 350-360, 1996.

Brown, S.: Estimating Biomass and Biomass Change of Tropical Forests, FAO, Forest Resources Assessment, Food and Agric. Org., Rome, 1997.

Brown, S. and Lugo, A. E.: Aboveground biomass estimates for tropical moist forests of the Brazilian Amazon, Interciencia, 17(1), 8-18, 1992.

Burling, I. R., Yokelson, R. J., Griffith, D. W. T., Johnson, T. J., Veres, P., Roberts, J. M., Warneke, C., Urbanski, S. P., Reardon, J., Weise, D. R., Hao, W. M., and de Gouw, J.: Laboratory measurements of trace gas emissions from biomass burning of fuel types from the southeastern and southwestern United States, Atmos. Chem. Phys., 10, 11115-11130, doi:10.5194/acp10-11115-2010, 2010.

Burling, I. R., Yokelson, R. J., Akagi, S. K., Urbanski, S. P., Wold, C. E., Griffith, D. W. T., Johnson, T. J., Reardon, J., and Weise, D. R.: Airborne and ground-based measurements of the trace gases and particles emitted by biomass burning, in preparation, 2011.

Cahoon Jr., D. R., Stocks, B. J., Levine, J. S., Cofer III., W. R., and Pierson, J. M.: Satellite analysis of the severe 1987 forest fires in northern China and southeastern Siberia, J. Geophys. Res., 99, 18627-18638, 1994.

Cahoon, D. R., Stocks, B. J., Levine, J. S., Cofer III., W. R., and Barber, J. A.: Monitoring 1992 forest fires in the boreal ecosystem using NOAA AVHRR satellite imagery, in: Biomass Burning and Climate Change, edited by: Levine, J. S., MIT Press, Cambridge, MA, 795-802, 1996.

Campbell, J., Donato, D., Azuma, D., and Law, B.: Pyrogenic carbon emission from a large wildfire in Oregon, United States, J. Geophys. Res., 112, G04014, doi:10.1029/2007JG000451, 2007.

Cançado, J. E. D., Saldiva, P. H. N., Pereira, L. A. A., Lara, L. B. L. S., Artaxo, P., Martinelli, L. A., Arbex, M. A., Zanobetti, A., and Braga, A. L. F.: The Impact of Sugar Cane - Burning Emissions on the Respiratory System of Children and the Elderly, Environ. Health Persp., 114, 725-729, 2006.

Capes, G., Murphy, J. G., Reeves, C. E., McQuaid, J. B., Hamilton, J. F., Hopkins, J. R., Crosier, J., Williams, P. I., and Coe, H.: Secondary organic aerosol from biogenic VOCs over West Africa during AMMA, Atmos. Chem. Phys., 9, 3841-3850, doi:10.5194/acp-9-3841-2009, 2009.

Cardille, J. A. and Foley, J. A.: Agricultural land-use change in Brazilian Amazonia between 1980 and 1995: Evidence from integrated satellite and census data, Remote Sens. Environ., 87, 551-562, 2003.

Carvalho Jr., J. A., Higuchi, N., Araújo, T. M., and Santos, J. C.: Combustion completeness in a rainforest clearing experiment in Manaus, Brazil, J. Geophys. Res., 103(D11), 13195-13199,
1998.

Carvalho Jr., J. A., Costa, F. S., Gurgel Veras, C. A., Sandberg, D. V., Alvarado, E. C., Gielow, R., Serra Jr., A. M., and Santos, J. C.: Biomass fire consumption and carbon release rates of rainforestclearing experiments conducted in northern Mato Grosso, Brazil, J. Geophys. Res., 106(D16), 17877-17887, 2001.

Cecelski, E., Dunkerley, J., and Ramsay, W.: Household energy and the poor in the third world, Resources for the Future, Inc. Washington, D. C., 1979.

Chakrabarty, R. K., Moosmüller, H., Chen, L.-W. A., Lewis, K., Arnott, W. P., Mazzoleni, C., Dubey, M. K., Wold, C. E., Hao, W. M., and Kreidenweis, S. M.: Brown carbon in tar balls from smoldering biomass combustion, Atmos. Chem. Phys., 10, 6363-6370, doi:10.5194/acp-10-6363-2010, 2010.

Chidumayo, E. M.: Inventory of wood used in charcoal production in Zambia, Final Report to Kate Newman, Biodiversity Support Program, World Wildlife Fund, Washington, D. C., 1994.

Chang, D. and Song, Y.: Estimates of biomass burning emissions in tropical Asia based on satellite-derived data, Atmos. Chem. Phys., 10, 2335-2351, doi:10.5194/acp-10-2335-2010, 2010a.

Chang, D. and Song, Y.: Corrigendum to "Estimates of biomass burning emissions in tropical Asia based on satellite-derived data" published in Atmos. Chem. Phys., 10, 2335-2351, 2010, Atmos. Chem. Phys., 10, 2613-2613, doi:10.5194/acp-10-26132010, 2010b

Chen, L.-W. A., Moosmuller, H., Arnott, W. P., Chow, J. C., and Watson, J. G.: Particle emissions from laboratory combustion of wildland fuels: In situ optical and mass measurements, Geophys. Res. Lett., 33, L04803, doi:10.1029/2005GL024838, 2006.

Christian, T., Kleiss, B., Yokelson, R. J., Holzinger, R., Crutzen, P. J., Hao, W. M., Saharjo, B. H., and Ward, D. E.: Comprehensive laboratory measurements of biomass-burning emissions: 1 Emissions from Indonesian, African, and other fuels, J. Geophys. Res., 108(D23), 4719, doi:10.1029/2003JD003704, 2003.

Christian, T. J., Kleiss, B., Yokelson, R. J., Holzinger, R., Crutzen, P. J., Hao, W. M., Shirai, T., and Blake, D. R.: Comprehensive laboratory measurements of biomass-burning emissions: 2, First intercomparison of open path FTIR, PTR-MS, GC-MS/FID/ECD, J. Geophys. Res., 109, D02311, doi:10.1029/2003JD003874, 2004.

Christian, T. J., Yokelson, R. J., Carvalho Jr., J. A., Griffith, D. W. T., Alvarado, E. C., Santos, J. C., Neto, T. G. S., Veras, C. A. G., and Hao, W. M.: The tropical forest and fire emissions experiment: Trace gases emitted by smoldering logs and dung from deforestation and pasture fires in Brazil, J. Geophys. Res., 112, D18308, doi:10.1029/2006JD008147, 2007.

Christian, T. J., Yokelson, R. J., Cárdenas, B., Molina, L. T., Engling, G., and Hsu, S.-C.: Trace gas and particle emissions from domestic and industrial biofuel use and garbage burning in central Mexico, Atmos. Chem. Phys., 10, 565-584, doi:10.5194/acp-10-565-2010, 2010.

Clinton, N. E., Gong, P., and Scott, K.: Quantification of pollutants emitted from very large wildland fires in Southern California, USA, Atmos. Environ., 40, 3686-3695, 2006.

Cofer III., W. R., Levine, J. S., Riggan, P. J., Sebacher, D. I., Winstead, E. L., Shaw Jr., E. F., Brass, J. A., and Ambrosia, V. G.: Trace gas emissions from a mid-latitude prescribe chaparral fire, J. Geophys. Res., 93(D12), 1653-1658, 1988.

Cofer III., W. R., Levine, J. S., Winstead, E. L., Stocks, B. J., 
Cahoon, D. R., and Pinto, J. P.: Trace gas emissions from tropical biomass fires: Yucatan peninsula, Mexico, Atmos. Environ., 27a, 1903-1907, 1993.

Cofer III., W. R., Winstead, E. L., Stocks, B. J., Goldammer, J. G., and Cahoon, D. R.: Crown fire emissions of $\mathrm{CO}_{2}, \mathrm{CO}, \mathrm{H}_{2}, \mathrm{CH}_{4}$, and TNMHC from a dense jack pine boreal forest fire, Geophys. Res. Lett., 25(21), 3919-3922, 1998.

Costner, P.: Estimating Releases and Prioritizing Sources in the Context of the Stockholm Convention: Dioxin Emission Factors for Forest Fires, Grassland and Moor Fires, Open Burning of Agricultural Residues, Open Burning of Domestic Waste, Landfill and Dump Fires, The International POPs Elimination Project, Mexico, 2005.

Costner, P.: Update of Dioxin Emission Factors for Forest Fires, Grassland and Moor Fires, Open Burning of Agricultural Residues, Open Burning of Domestic Waste, Landfills and Dump Fires, International POPs Elimination Network, Mexico, 2006.

Crounse, J. D., McKinney, K. A., Kwan, A. J., and Wennberg, P. O.: Measurement of gas-phase hydroperoxides by chemical ionization mass spectrometry, Anal. Chem., 78(19), 6726-6732, 2006.

Crounse, J. D., DeCarlo, P. F., Blake, D. R., Emmons, L. K., Campos, T. L., Apel, E. C., Clarke, A. D., Weinheimer, A. J., McCabe, D. C., Yokelson, R. J., Jimenez, J. L., and Wennberg, P. O.: Biomass burning and urban air pollution over the Central Mexican Plateau, Atmos. Chem. Phys., 9, 4929-4944, doi:10.5194/acp-9-4929-2009, 2009.

Crutzen, P. J. and Andreae, M. O.: Biomass burning in the tropics: Impact on atmospheric chemistry and biogeochemical cycles, Science, 250, 1669-1678, 1990.

Crutzen, P. J., Heidt, L. E., Krasnec, J. P., Pollock, W. H., and Seiler, W.: Biomass burning as a source of atmospheric gases $\mathrm{CO}, \mathrm{H}_{2}$, $\mathrm{N}_{2} \mathrm{O}, \mathrm{CH}_{3} \mathrm{Cl}$, and COS, Nature, 282, 253-256, 1979.

DeFries, R., Hansen, M., Townshend, J. R. G., Janetos, A. C., and Loveland, T. R.: A new global $1 \mathrm{~km}$ data set of percent tree cover derived from remote sensing, Glob. Change Biol., 6, 247-254, 2000.

de Gouw, J. A., Warneke, C., Parrish, D. D., Holloway, J. S., Trainer, M., and Fehsenfeld, F. C.: Emission sources and ocean uptake of acetonitrile $\left(\mathrm{CH}_{3} \mathrm{CN}\right)$ in the atmosphere, J. Geophys. Res., 108(D11), 4329, doi:10.1029/2002JD002897, 2003.

de Gouw, J. A., Warneke, C., Stohl, A., Wollny, A. G., Brock, C. A., Cooper, O. R., Holloway, J. S., Trainer, M., Fehsenfeld, F. C., Atlas, E. L., Donnelly, S. G., Stroud, V., and Lueb, A.: Volatile organic compounds composition of merged and aged forest fire plumes from Alaska and western Canada, J. Geophys. Res., 111, D10303, doi:10.1029/2005JD006175, 2006.

de Groot, W. J., Pritchard, J. M., and Lynham, T. J.: Forest floor fuel consumption and carbon emissions in Canadian boreal forest fires, Can. J. Forest Res., 39, 367-382, 2009.

Desanker, P. V., Frost, P. G. H., Justice, C. O., and Scholes, R. J.: The Miombo network: framework for a terrestrial transect study of land-use and land-cover change in the Miombo ecosystems of central Africa, IGBP Report 41, IGBP Secr., R. Swed. Acad. of Sci., Stockholm, Sweden, 1997.

Dherani, M., Pope, D., Mascarenhas, M., Smith, K. R., Weber, M., and Bruce, N.: Indoor air pollution from unprocessed solid fuel use and pneumonia risk in children aged under five years: a systematic review and meta-analysis, B. World Health Organ., 86(5), 390-398, 2008.
Eck, T. F., Holben, B. N., Reid, J. S., O’Neill, N. T., Schafer, J. S., Dubovik, O., Smirnov, A., Yamasoe, M. A., and Artaxo, P.: High aerosol optical depth biomass burning events: A comparison of optical properties for different source regions, Geophys. Res. Lett., 30, 2035, doi:10.1029/2003GL017861, 2003.

Engling, G., Carrico, C. M., Kreidenweis, S. M., Collett Jr., J. L., Day, D. E., Malm, W. C., Lincoln, E., Hao, W. M., Iinuma, Y., and Herrmann, H.: Determination of levoglucosan in biomass combustion aerosol by high-performance anion-exchange chromatography with pulsed amperometric detection, Atmos. Environ., 40, S299-S311, 2006.

Fast, J., Aiken, A. C., Allan, J., Alexander, L., Campos, T., Canagaratna, M. R., Chapman, E., DeCarlo, P. F., de Foy, B., Gaffney, J., de Gouw, J., Doran, J. C., Emmons, L., Hodzic, A., Herndon, S. C., Huey, G., Jayne, J. T., Jimenez, J. L., Kleinman, L., Kuster, W., Marley, N., Russell, L., Ochoa, C., Onasch, T. B., Pekour, M., Song, C., Ulbrich, I. M., Warneke, C., WelshBon, D., Wiedinmyer, C., Worsnop, D. R., Yu, X.-Y., and Zaveri, R.: Evaluating simulated primary anthropogenic and biomass burning organic aerosols during MILAGRO: implications for assessing treatments of secondary organic aerosols, Atmos. Chem. Phys., 9, 6191-6215, doi:10.5194/acp-9-6191-2009, 2009.

Fearnside, P. M., Leal Jr., N., and Fernandes, F. M.: Rainforest burning and the global carbon budget: biomass, combustion efficiency, and charcoal formation in the Brazilian Amazon, J. Geophys. Res., 98, 16733-16743, 1993.

Ferek, R. J., Reid, J. S., Hobbs, P. V., Blake, D. R., and Liousse, C.: Emission factors of hydrocarbons, halocarbons, trace gases, and particles from biomass burning in Brazil, J. Geophys. Res., 103(D24), 32107-32118, doi:10.1029/98JD00692, 1998.

Fernandes, S. D., Trautmann, N. M., Streets, D. G., Roden, C. A., and Bond, T. C.: Global biofuel use, 1850-2000, Global Biogeochem. Cy., 21, GB2019, doi:10.1029/2006GB002836, 2007.

Finlayson-Pitts, B. J. and Pitts Jr., J. N.: Chemistry of the Upper and Lower Atmosphere, Academic Press, San Diego, USA, 2000.

FIRESCAN Science Team: Fire in Ecosystems of Boreal Eurasia: The Bor Forest Island Fire Experiment Fire Research Campaign Asia-North (FIRESCAN), in: Biomass Burning and Global Change, edited by: Levine, J. S., MIT Press, Cambridge, MA., 848-873, 1996.

Fishman, J., Fakhruzzaman, K., Cros, B., and Nganga, D.: Identification of widespread pollution in the Southern Hemisphere deduced from satellite analyses, Science, 252, 1693-1696, 1991.

Forster, P., Ramaswamy, V., Artaxo, P., Berntsen, T., Betts, R., Fahey, D. W., Haywood, J., Lean, J., Lowe, D. C., Myhre, G., Nganga, J., Prinn, R., Raga, G., Schulz, M., and Van Dorland, R.: Changes in Atmospheric Constituents and in Radiative Forcing, in: Climate Change 2007: The Physical Science Basis, contribution of Working Group I to the Fourth Assessment Report of the Intergovernmental Panel on Climate Change, edited by: Solomon, S. D., Qin, M., Manning, Z., Chen, M., Marquis, K B., Averyt, M. T., and Miller, H. L., Cambridge University Press, Cambridge, United Kingdom and New York, NY, USA, 129134, 2007.

French, N. H. F., Goovaerts, P., and Kasischke, E. S.: Uncertainty in estimating carbon emissions from boreal forest fires, J. Geophys. Res., 109, D14S08, doi:10.1029/2003JD003635, 2004.

Friedl, M. A., McIver, D. K., Hodges, J. C. F., Zhang, X. Y., Muchoney, D., Strahler, A. H., Woodcock, C. E., Gopal, S., 
Schneider, A., Cooper, A., Baccini, A., Gao, F., and Schaaf, C.: Global land cover mapping from MODIS: algorithms and early results, Remote Sens. Environ., 83, 287-302, 2002.

Giglio, L., van der Werf, G. R., Randerson, J. T., Collatz, G. J., and Kasibhatla, P.: Global estimation of burned area using MODIS active fire observations, Atmos. Chem. Phys., 6, 957974, doi:10.5194/acp-6-957-2006, 2006.

Giglio, L., Randerson, J. T., van der Werf, G. R., Kasibhatla, P. S., Collatz, G. J., Morton, D. C., and DeFries, R. S.: Assessing variability and long-term trends in burned area by merging multiple satellite fire products, Biogeosciences, 7, 1171-1186, doi:10.5194/bg-7-1171-2010, 2010.

Goode, J. G., Yokelson, R. J., Susott, R. A., and Ward, D. E.: Trace gas emissions from laboratory biomass fires measured by openpath FTIR: Fires in grass and surface fuels, J. Geophys. Res., 104, 21237-21245, doi:10.1029/1999JD900360, 1999.

Goode, J. G., Yokelson, R. J., Ward, D. E., Susott, R. A., Babbitt, R. E., Davies, M. A., and Hao, W. M.: Measurements of excess $\mathrm{O}_{3}, \mathrm{CO}_{2}, \mathrm{CO}, \mathrm{CH}_{4}, \mathrm{C}_{2} \mathrm{H}_{4}, \mathrm{C}_{2} \mathrm{H}_{2}, \mathrm{HCN}, \mathrm{NO}, \mathrm{NH}_{3}$, $\mathrm{HCOOH}, \mathrm{CH}_{3} \mathrm{COOH}, \mathrm{HCHO}$, and $\mathrm{CH}_{3} \mathrm{OH}$ in 1997 Alaskan biomass burning plumes by airborne Fourier transform infrared spectroscopy (AFTIR), J. Geophys. Res., 105(D17), 2214722166, doi:10.1029/2000JD900287, 2000.

Grieshop, A. P., Logue, J. M., Donahue, N. M., and Robinson, A. L.: Laboratory investigation of photochemical oxidation of organic aerosol from wood fires 1: measurement and simulation of organic aerosol evolution, Atmos. Chem. Phys., 9, 1263-1277, doi:10.5194/acp-9-1263-2009, 2009.

Guenther, A., Karl, T., Harley, P., Wiedinmyer, C., Palmer, P. I., and Geron, C.: Estimates of global terrestrial isoprene emissions using MEGAN (Model of Emissions of Gases and Aerosols from Nature), Atmos. Chem. Phys., 6, 3181-3210, doi:10.5194/acp-63181-2006, 2006.

Guild, L. S., Kauffman, J. B., Ellingson, L. J., Cummings, D. L., and Castro, E. A.: Dynamics associated with total aboveground biomass, C, nutrient pools, and biomass burning of primary forest and pasture in Rondônia, Brazil during SCAR-B, J. Geophys. Res., 103(D24), 32091-32100, 1998.

Hansen, M. C., DeFries, R. S., Townshend, J. R. G., and Sohlberg, R.: Global land cover classification at $1 \mathrm{~km}$ spatial resolution using a classification tree approach, Int. J. Remote Sens., 21, 13311364,2000

Hansen, M., DeFries, R. S., Townshend, J. R. G., Carroll, M., Dimiceli, C., and Sohlberg, R. A.: Global percent tree cover at a spatial resolution of 500 meters: first results of the MODIS vegetation continuous fields algorithm, Earth Interact., 7(10), 1-15, 2003

Hardy, C. C., Conard, S. G., Regelbrugge, J. C., and Teesdale, D. R.: Smoke emissions from prescribed burning of southern California chaparral, Res. Pap. PNW-RP-486, U.S. Department of Agriculture, Forest Service, Pacific Northwest Research Station, Portland, OR., 1996.

Hawbaker, T. J., Radeloff, V. C., Syphard, A. D., Zhu, Z., and Stewart, S. I.: Detection rates of the MODIS active fire product in the United States, Remote Sens. Environ., 112(5), 2656-2664, 2008.

Haywood, J. and Boucher, O.: Estimates of the direct and indirect radiative forcing due to tropospheric aerosols: A review, Rev. Geophys., 38(4), 513-543, doi:10.1029/1999RG000078, 2000.

Hobbs, P. V., Reid, J. S., Kotchenruther, R. A., Ferek, R. J., and
Weiss, R.: Direct Radiative Forcing by Smoke from Biomass Burning, Science, 275(5307), 1777-1778, 1997.

Hobbs, P. V., Sinha, P., Yokelson, R. J., Christian, T. J., Blake, D. R., Gao, S., Kirchstetter, T. W., Novakov, T., and Pilewskie, P.: Evolution of gases and particles from a savanna fire in South Africa, J. Geophys. Res., 108(D13), 8485, doi:10.1029/2002JD002352, 2003.

Hoffa, E. A., Ward, D. E., Hao, W. M., Susott, R. A., and Wakimoto, R. H.: Seasonality of carbon emissions from biomass burning in a Zambian savanna, J. Geophys. Res., 104(D11), 13841-13853, 1999.

Holzinger, R., Warneke, C., Hansel, A., Jordan, A., Lindinger, W., Scharffe, D., Schade, G., and Crutzen, P. J.: Biomass burning as a source for formaldehyde, acetaldehyde, methanol, acetone, acetonitrile, and hydrogen cyanide, Geophys. Res. Lett., 26, 11611164, 1999.

Hopkins, R. J., Lewis, K., Desyaterik, Y., Wang, Z., Tivanski, A. V., Arnott, W. P., Laskin, A., and Gilles, M. K.: Correlations between optical, chemical and physical properties of biomass burn aerosols, Geophys. Res. Lett., 34, L18806, doi:10.1029/2007GL030502, 2007.

Hughes, R. F., Kauffman, J. B., and Jaramillo, V. J.: Ecosystemscale impacts of deforestation and land use in a humid tropical region of Mexico, Ecol. Appl., 10(2), 515-527, 2000.

Hurst, D. F., Griffith, D. W. T., Carras, J. N., Williams, D. J., and Fraser, P. J.: Measurements of trace gases emitted by Australian savanna fires during the 1990 dry season, J. Atmos. Chem., 18, 33-56, 1994a.

Hurst, D. F., Griffith, D. W. T., and Cook, G. D.: Trace gas emissions from biomass burning in tropical Australian savannas, J. Geophys. Res., 99, 16441-16456, 1994b.

Ishengoma, R. C., Gillah, P. R., Majaliw, A. S., and Rao, R. V.: The quality of charcoal produced from Leucanea leucocephalia in earth kilns from Tanzania, Indian J. For., 20, 265-268, 1997.

Jacob, D. J., Wofsy, S. C., Bakwin, P. S., Fan, S.-M, Harriss, R. C., Talbot, R. W., Bradshaw, J. D., Sandholm, S. T., Singh, H. B., Browell, E. V., Gregory, G. L., Sachse, G. W., Shipham, M. C., Blake, D. R., and Fitzjarrald, D. R.: Summertime photochemistry of the troposphere at high northern latitudes, J. Geophys. Res., 97(D15), 16421-16431, 1992.

Jacobs, M.: The tropical rain forest: A first encounter, SpringerVerlag, New York, USA, 1988.

Jaramillo, V. J., Kauffman, J. B., Rentería-Rodríguez, L., Cummings, D. L., and Ellingson, L. J.: Biomass, carbon, and nitrogen pools in Mexican tropical dry forest landscapes, Ecosystems, 6, 609-629, 2003.

Johnson, M., Edwards, R., Frenk, C. A., and Masera, O.: Infield greenhouse gas emissions from cookstoves in rural Mexican households, Atmos. Environ., 42, 1206-1222, 2008.

Johnson, T. J., Profeta, L. T. M., Sams, R. L., Griffith, D. W. T., and Yokelson, R. J.: An infrared spectral database for detection of gases emitted by biomass burning, Vib. Spectrosc., 53, 97-102, 2010.

Jordan, A., Haidacher, S., Hanel, G., Hartungen, E., Märk, L., Seehauser, H., Schottkowsky, R., Sulzer, P., and Märk, T. D.: A high resolution and high sensitivity time-of-flight protontransfer-reaction mass spectrometer (PTR-TOF-MS), Int. J. Mass Spectrom., 2-3(286), 122-128, 2009.

Jost, C., Trentmann, J., Sprung, D., Andreae, M. O., McQuaid, J. 
B., and Barjat, H.: Trace gas chemistry in a young biomass burning plume over Namibia: observations and model simulations, J. Geophys. Res., 108(D13), 8482, doi:10.1029/2002JD002431, 2003.

Kállai, M., Máté, V., and Balla, J.: Effects of experimental conditions on the determination of the effective carbon number, Chromatographia, 57, 639-644, doi:10.1007/BF02491742, 2003.

Karl, T., Hansel, A., Mark, T., Lindinger, W., and Hoffmann, D.: Trace gas monitoring at the Mauna Loa Baseline observatory using proton-transfer reaction mass spectrometry, Int. J. Mass Spectrom., 223, 527-538, 2003.

Karl, T. G., Christian, T. J., Yokelson, R. J., Artaxo, P., Hao, W. M., and Guenther, A.: The Tropical Forest and Fire Emissions Experiment: method evaluation of volatile organic compound emissions measured by PTR-MS, FTIR, and GC from tropical biomass burning, Atmos. Chem. Phys., 7, 5883-5897, doi:10.5194/acp-7-5883-2007, 2007.

Kasischke, E. S., Bergen, K., Fennimore, R., Sotelo, F., Stephens, G., Janetos, A., and Shugart, H. H.: Satellite imagery gives a clear picture of Russia's boreal forest fires, EOS, Trans. Amer. Geophys. Union., 80, 141-152, 1999.

Kauffman, J. B., Sanford, R. L., Cummings, D. L., Salcedo, I. H., and Sampaio, E. V. S. B.: Biomass and nutrient dynamics associated with slash fires in neotropical dry forests, Ecology, 74, 140-151, 1993.

Kauffman, J. B., Cummings, D. L., Ward, D. E., and Babbitt, R.: Fire in the Brazilian Amazon: 1. Biomass, nutrient pools, and losses in slashed primary forests, Oecologia, 104, 397-408, 1995.

Kauffman, J. B., Cummings, D. L., and Ward, D. E.: Fire in the Brazilian Amazon 2. Biomass, nutrient pools and losses in cattle pastures, Oecologia, 113, 415-427, 1998.

Kauffman, J. B., Steele, M. D., Cummings, D. L., and Jaramillo, V. J.: Biomass dynamics associated with deforestation, fire, and, conversion to cattle pasture in a Mexican tropical dry forest, Forest Ecol. Manag., 176, 1-12, 2003.

Kaufman, Y. J., Justice, C. O., Flynn, L. P., Kendall, J. D., Prins, E. M., Giglio, L., Ward, D. E., Menzel, W. P., and Setzer, A. W.: Potential global fire monitoring from EOS-MODIS, J. Geophys. Res., 103, 32215-32238, 1998.

Keene, W. C., Lobert, J. M., Crutzen, P. J., Maben, J. R., Scharffe, D. H., Landmann, T., Hély, C., and Brain, C.: Emissions of major gaseous and particulate species during experimental burns of southern African biomass, J. Geophys. Res., 111, D04301, doi:10.1029/2005JD006319, 2006.

Kituyi, E., Marufu, L., Wandiga, S. O., Jumba, I. O., Andreae, M. O., and Helas, G.: Carbon monoxide and nitric oxide from biofuel fires in Kenya, Energ. Convers. Manage., 42, 1517-1542, 2001.

Kopacz, M., Jacob, D. J., Fisher, J. A., Logan, J. A., Zhang, L., Megretskaia, I. A., Yantosca, R. M., Singh, K., Henze, D. K., Burrows, J. P., Buchwitz, M., Khlystova, I., McMillan, W. W., Gille, J. C., Edwards, D. P., Eldering, A., Thouret, V., and Nedelec, P.: Global estimates of CO sources with high resolution by adjoint inversion of multiple satellite datasets (MOPITT, AIRS, SCIAMACHY, TES), Atmos. Chem. Phys., 10, 855-876, doi:10.5194/acp-10-855-2010, 2010.

Korontzi, S., Roy, D. P., Justice, C. O., and Ward, D. E.: Modeling and sensitivity analysis of fire emissions in southern Africa dur- ing SAFARI 2000, Remote Sens. Environ., 92, 255-275, 2004. Lacaux, J.-P., Brocard, D., Lacaux, C., Delmas, R., Brou, A., Yoboué, V., and Koffi, M.: Traditional charcoal making: an important source of atmospheric pollution in the African Tropics, Atmos. Res., 35, 71-76, 1994.

Lapina, K., Honrath, R. E., Owen, R. C., Val Martín, M., and Pfister, G.: Evidence of significant large-scale impacts of boreal fires on ozone levels in the midlatitude Northern Hemisphere free troposphere, Geophys. Res. Lett., 33, L10815, doi:10.1029/2006GL025878, 2006.

Lara, L. L., Artaxo, P., Martinelli, L. A., Camargo, P. B., Victoria, R. L., and Ferraz, E. S. B.: Properties of aerosols from sugarcane burning emissions in Southeastern Brazil, Atmos. Environ., 39, 4627-4637, 2005.

Lefer, B. L., Talbot, R. W., Harriss, R. C., Bradshaw, J. D., Sandholm, S. T., Olson, J. O., Sachse, G. W., Collins, J., Shipham, M. A., Blake, D. R., Klemm, K. I., Klemm, O., Gorzelska, K., and Barrick, J.: Enhancement of acidic gases in biomass burning impacted air masses over Canada, J. Geophys. Res., 99(D1), 1721-1737, 1994.

Lelieveld, J., Butler, T. M., Crowley, J. N., Dillon, T. J., Fischer, H., Ganzeveld, L., Harder, H., Lawrence, M. G., Martinez, M., Taraborrelli, D., and Williams, J.: Atmospheric oxidation capacity sustained by a tropical forest, Nature, 452, 737-740, 2008.

Lemieux, P. M., Lutes, C. C., Abbott, J. A., and Aldous, K. M.: Emissions of polychlorinated dibenzo-p-dioxins and polychlorinated dibenzofurans from the open burning of household waste in barrels, Environ. Sci. Technol., 34, 377-384, 2000.

Lemieux, P. M., Lutes, C. C., and Santoianni, D. A.: Emissions of organic air toxics from open burning: a comprehensive review, Prog. Energ. Combust., 20, 1-32, 2004.

Li, Q., Jacob, D. J., Bey, I., Yantosca, R. M., Zhao, Y., Kondo, Y., and Notholt, J.: Atmospheric hydrogen cyanide (HCN): biomass burning source, ocean sink?, Geophys. Res. Lett., 27(3), 357$360,2000$.

Li, Q., Jacob, D. J., Yantosca, R. M., Heald, C. L., Singh, H. B., Koike, M., Zhao, Y., Sachse, G. W., and Streets, D. G.: A global three-dimensional model analysis of the atmospheric budgets of $\mathrm{HCN}$ and $\mathrm{CH}_{3} \mathrm{CN}$ : Constraints from aircraft and ground measurements, J. Geophys. Res., 108(D21), 8827, doi:10.1029/2002JD003075, 2003.

Lindinger, W., Jordan, A., and Hansel, A.: Proton-transfer-reaction mass spectroscopy (PTR-MS): On-line monitoring of volatile organic compounds at pptv levels, Chem. Soc. Rev., 27, 347-534, 1998.

Lobert, J. M., Keene, W. C., Logan, J. A., and Yevich, R.: Global chlorine emissions from biomass burning: Reactive Chlorine Emissions Inventory, J. Geophys. Res., 104(D7), 8373-8389, 1999.

Ludwig, J., Marufu, L. T., Huber, B., Andreae, M. O., and Helas, G.: Domestic combustion of biomass fuels in developing countries: a major source of atmospheric pollutants, J. Atmos. Chem., 44, 23-37, 2003.

Madronich, S.: Photodissociation in the Atmosphere 1. Actinic flux and the effects of ground reflections and clouds, J. Geophys. Res., 92(D8), 9740-9752, 1987.

Magi, B. I.: Chemical apportionment of southern African aerosol mass and optical depth, Atmos. Chem. Phys., 9, 7643-7655, doi:10.5194/acp-9-7643-2009, 2009. 
Masera, O. R., Díaz, R., and Berrueta, V. M.: From cookstoves to cooking systems: the integrated program on sustainable household energy use in Mexico, Energ. Sustain. Dev., 9(1), 25-36, 2005.

Mason, S. A., Trentmann, J., Winterrath, T., Yokelson, R. J., Christian, T. J., Carlson, L. J., Warner, T. R., Wolfe, L. C., and Andreae, M. O.: Intercomparison of two box models of the chemical evolution in biomass-burning smoke plumes, J. Atmos. Chem., 55, 273-297, doi:10.1007/S10874-006-9039-5, 2006.

Matthews, E.: Global vegetation and land use: New high-resolution data bases for climate studies, J. Clim. Appl. Meteorol., 22, 474487, 1983.

Mazzoleni, L. R., Zielinska, B., and Moosmüller, H.: Emissions of levoglucosan, methoxy phenols, and organic acids from prescribed burns, laboratory combustion of wildland fuels, and residential wood combustion, Environ. Sci. Technol., 41, 21152122, 2007.

McMeeking, G. R., Kreidenweis, S. M., Baker, S., Carrico, C. M., Chow, J. C., Collet Jr., J. L., Hao, W. M., Holden, A. S., Kirchstetter, T. W., Malm, W. C., Moosmüller, H., Sullivan, A. P., and Wold, C. E.: Emissions of trace gases and aerosols during the open combustion of biomass in the laboratory, J. Geophys. Res., 114, D19210, doi:10.1029/2009JD011836, 2009.

Mooney, H. A., Bullock, S. H., and Medina, E.: Introduction, in: Seasonally dry tropical forests, edited by: Bullock, S. H. and Mooney, H. A., Cambridge University Press, Cambridge, 1-8, 1995.

Morton, D. C., DeFries, R. S., Shimabukuro, Y. E., Anderson, L. O., Arai, E., Espirito-Santo, F., Freitas, R., and Morisette, J.: Cropland expansion changes deforestation dynamics in the southern Brazilian Amazon, P. Natl. Acad. Sci., 103(39), 14637-14641, 2006.

Mutch, R. W.: Fighting fire with prescribed fire: A return to ecosystem health, J. Forest., 92, 31-33, 1994.

Nance, J. D., Hobbs, P. V., Radke, L. F., and Ward, D. E.: Airborne measurements of gases and particles from an Alaskan wildfire, J. Geophys. Res., 98, 14873-14882, 1993.

Neary, D. G., Ryan, K. C., DeBano, L. F., Landsberg, J. D., and Brown, J. K.: Chapter 1: Introduction, in: Wildland fire and ecosystems, 2005, edited by: Neary, D. G., Ryan, K. C., and DeBano, L. F., Department of Agriculture, Forest Service, Rocky Mountain Research Station, Ogden, UT., 1-17, 2005.

Osthoff, H. D., Roberts, J. M., Ravishankara, A. R., Williams, E. J., Lerner, B. M., Sommariva, R., Bates, T. S., Coffman, D., Quinn, P. K., Dibb, J. E., Stark, H., Burkholder, J. B., Talukdar, R. K., Meagher, J., Fehsenfeld, F. C., and Brown, S. S.: High levels of nitryl chloride in the polluted subtropical marine boundary layer, Nat. Geosci., 1, 324-328, 2008.

Ottmar, R. D. and Sandberg, D. V.: Predicting forest floor consumption from wildland fire in boreal forests of Alaska - preliminary results, Proceedings of Fire Conference 2000: The first national congress on fire ecology, prevention, and management, edited by: Galley, K. E. M., Klinger, R. C., and Sugihara, N. G., Miscellaneous Publication No. 13, Tall Timbers Research Station, Tallahassee, FL., 218-224, 2003.

Ottmar, R. D., Vihnanek, R. E., and Regelbrugge, J. C.: Stereo photo series for quantifying natural fuels, Volume IV: pinyonjuniper, sagebrush, and chaparral types in the Southwestern United States, National Wildfire Coordinating Group, National Intera- gency Fire Center, Boise, ID., 2000.

Page, S. E., Siegert, F., Rieley, J. O., Boehm, H. D. V., Jaya, A., and Limin, S.: The amount of carbon released from peat and forest fires in Indonesia during 1997, Nature, 420, 61-65, 2002.

Paulot, F., Crounse, J. D., Kjaergaard, H. G., Kürten, A., St. Clair, J. M., Seinfeld, J. H., and Wennberg, P. O.: Unexpected epoxide formation in the gas-phase photooxidation of isoprene, Science, 325, 730-733, 2009.

Peeters, J., Nguyen, T. L., and Vereecken, L.: $\mathrm{HO}_{\mathrm{x}}$ radical regeneration in the oxidation of isoprene, Phys. Chem. Chem. Phys., 11, 5935-5939, 2009.

Pennise, D. M., Smith, K. R., Kithinji, J. P., Rezende, M. E., Raad, T. J., Zhang, J., and Fan, C.: Emissions of greenhouse gases and other airborne pollutants from charcoal making in Kenya and Brazil, J. Geophys. Res., 106(D20), 24143-24155, 2001.

Pfister, G., Emmons, L., and Wiedinmyer, C.: Impacts of the Fall 2007 California wildfires on surface ozone: Integrating local observations with global model simulations, Geophys. Res. Lett., 35, L19814, doi:10.1029/2008GL034747, 2007.

Pickford, S., Suharti, M., and Wibowo, A.: A note on fuelbeds and fire behavior in alang-alang (Imperata cylindrica), Int. J. Wildland Fire, 2, 41-46, 1992.

Radke, L. F., Hegg, D. A., Hobbs, P. V., Nance, J. D., Lyons, J. H., Laursen, K. K., Weiss, R. E., Riggan, P. J., and Ward, D. E.: Particulate and trace gas emissions from large biomass fires in North America, in: Global biomass burning - Atmospheric, climatic, and biospheric implications, MIT Press, Cambridge, MA, 209-224, 1991.

Raff, J. D., Njegic, B., Chang, W. L., Gordon, M. S., Dabdub, D., Gerber, R. B., and Finlayson-Pitts, B. J.: Chlorine activation indoors and outdoors via surface-mediated reactions of nitrogen oxides with hydrogen chloride, P. Natl. Acad. Sci. USA, 106, 13647-13654, doi:10.1073/PNAS.0904195106, 2009.

Ramanathan, V. and Carmichael, G.: Global and regional climate changes due to black carbon, Nature, 1, 221-227, 2008.

Ranis, G. and Stewart, F.: V-goods and the role of the urban informal sector in development, Yale University Economic Growth Center Discussion Paper No. 724, New Haven, 1994.

Reid, J. S., Hobbs, P. V., Ferek, R. J., Martins, J. V., Blake, D. R., Dunlap, M. R., and Liousse, C.: Physical, chemical, and radiative characteristics of the smoke dominated regional hazes over Brazil, J. Geophys. Res., 103, 32059-32080, 1998.

Reid, J. S., Prins, E. M., Westphal, D. L., Schmidt, C. C., Richardson, K. A., Christopher, S. A., Eck, T. F., Reid, E. A., Curtis, C. A., and Hoffman, J. P.: Real-time monitoring of South American smoke particle emissions and transport using a coupled remote sensing/box-model approach, Geophys. Res. Lett., 31, L06107, doi:10.1029/2003GL018845, 2004.

Reid, J. S., Koppmann, R., Eck, T. F., and Eleuterio, D. P.: A review of biomass burning emissions part II: intensive physical properties of biomass burning particles, Atmos. Chem. Phys., 5, 799825, doi:10.5194/acp-5-799-2005, 2005a.

Reid, J. S., Eck, T. F., Christopher, S. A., Koppmann, R., Dubovik, O., Eleuterio, D. P., Holben, B. N., Reid, E. A., and Zhang, J.: A review of biomass burning emissions part III: intensive optical properties of biomass burning particles, Atmos. Chem. Phys., 5, 827-849, doi:10.5194/acp-5-827-2005, 2005b.

Reid, J. S., Hyer, E. J., Prins, E. M., Westphal, D. L., Zhang, J., Wang, J., Christopher, S. A., Curtis, C. A., Schmidt, C. C., 
Eleuterio, D. P., Richardson, K. A., and Hoffman, J. P.: Global monitoring and forecasting of biomass-burning smoke: Description and lessons from the Fire Locating and Modeling of Burning Emissions (FLAMBE) program, J. Sel. Topics Appl. Earth Obs. Rem. Sens., 2, 144-162, 2009.

Rein, G., Cohen, S., and Simeoni, A.: Carbon emissions from smouldering peat in shallow and strong fronts, P. Combust. Inst., 32, 2489-2496, 2009.

Roberts, J. M., Veres, P., Warneke, C., Neuman, J. A., Washenfelder, R. A., Brown, S. S., Baasandorj, M., Burkholder, J. B., Burling, I. R., Johnson, T. J., Yokelson, R. J., and de Gouw, J.: Measurement of HONO, HNCO, and other inorganic acids by negative-ion proton-transfer chemical-ionization mass spectrometry (NI-PT-CIMS): application to biomass burning emissions, Atmos. Meas. Tech., 3, 981-990, doi:10.5194/amt-3-981-2010, 2010.

Robinson, A. L., Donahue, N. M., Shrivastava, M. K., Weitkamp, E. A., Sage, A. M., Grieshop, A. P., Lane, T. E., Pierce, J. R., and Pandis, S. N.: Rethinking organic aerosols: Semivolatile emissions and photochemical aging, Science, 315(5816), 1259-1262, 2007.

Roden, C. A., Bond, T. C., Conway, S., and Pinel, A. B. O.: Emission factors and real-time optical properties of particles emitted from traditional wood burning cookstoves, Environ. Sci. Technol., 40(21), 6750-6757, doi:10.1021/ES052080I, 2006.

Roden, C. A., Bond, T. C., Conway, S., Pinel, A. B. O., MacCarty, N., and Still, D.: Laboratory and field investigations of particulate and carbon monoxide emissions from traditional and improved cookstoves, Atmos. Environ., 43, 1170-1181, 2009.

Rosenfeld, D.: TRMM observed first direct evidence of smoke from forest fires inhibiting rainfall, Geophys. Res. Lett., 26 (20), 3105-3108, 1999.

Rothman, L. S., Gordon, I. E., Barbe, A., Chris Benner, D., Bernath, P. F., Birk, M., Boudon, V., Brown, L. R., Campargue, A., Champion, J.-P., Chance, K., Coudert, L. H., Dana, V., Devi, V. M., Fally, S., Flaud, J.-P., Gamache, R. R., Goldman, A., Jacquemart, D., Kleiner, I., Lacome, N., Lafferty, W. J., Mandin, J.-Y., Massie, S. T., Mikhailenko, S. N., Miller, C. E., Moazzen-Ahmadi, N., Naumenko, O. V., Nikitin, A. V., Orphal, J., Perevalov, V. I., Perrin, A., Predoi-Cross, A., Rinsland, C. P., Rotger, M., Simeckova, M., Smith, M. A. H., Sung, K., Tashkun, S. A., Tennyson, J., Toth, R. A., Vandaele, A. C., and Vander Auwera, J.: The HITRAN 2008 molecular spectroscopic database, J. Quant. Spectrosc. Ra., 110, 533-572, 2009.

Roy, D. P. and Boschetti, L.: Southern Africa validation of the MODIS, L3JRC and GlobCarbon burned-area products, IEEE Geosci. Remote Sens., 47(4), 1032-1044, 2009.

Sah, J. P., Ross, M. S., Snyder, J. R., Koptur, S., and Cooley, H. C.: Fuel loads, fire regimes, and post-fire fuel dynamics in Florida Keys pine forests, Int. J. Wildland Fire, 15, 463-478, 2006.

Sander, S. P., Finlayson-Pitts, B. J., Friedl, R. R., Golden, D. M., Huie, R. E., Keller-Rudek, H., Kolb, C. E., Kurylo, M. J., Molina, M. J., Moortgat, G. K., Orkin, V. L., Ravishankara, A. R., and Wine, P. W.: Chemical kinetics and photochemical data for use in atmospheric studies, Evaluation Number 15 (JPL Publication 06-2), Jet Propulsion Laboratory, Pasadena, CA, 2006.

Savadogo, P., Zida, D., Sawadogo, L., Tiveau, D., Tigabu, M., and Oden, P. C.: Fuel and fire characteristics in savanna-woodland of West Africa in relation to grazing and dominant grass type, Int.
J. Wildland Fire, 16, 531-539, doi:10.1071/WF07011, 2007.

Seavoy, R.: The origin of tropical grasslands in Kalimantan, Indonesia, J. Trop. Geogr., 40, 48-52, 1975.

Schneider, F. and Enste, D. H.: Shadow economies: size, causes, and consequences, J. Econ. Lit., 38, 77-114, 2000.

Schwarz, J. P., Gao, R. S., Spackman, J. R., Watts, L. A., Thomson, D. S., Fahey, D. W., Ryerson, T. B., Peischl, J., Holloway, J. S., Trainer, M., Frost, G. J., Baynard, T., Lack, D. A., de Gouw, J. A., Warneke, C., and Del Negro, L. A.: Measurement of the mixing state, mass, and optical size of individual black carbon particles in urban and biomass burning emissions, Geophys. Res. Lett., 35, L13810, doi:10.1029/2008GL033968, 2008.

Seiler, W. and Crutzen, P. J.: Estimates of gross and net fluxes of carbon between the biosphere and the atmosphere from biomass burning, Climatic Change, 2, 207-247, 1980.

Shea, R. W., Shea, B. W., Kauffman, J. B., Ward, D. E., Haskins, C. I., and Scholes, M. C.: Fuel biomass and combustion factors associated with fires in savanna ecosystems of South Africa and Zambia, J. Geophys Res., 101(D19), 23551-23568, 1996.

Singh, H. B., Kanakidou, M., Crutzen, P. J., and Jacob, D. J.: High concentrations and photochemical fate of oxygenated hydrocarbons in the global atmosphere, Nature, 378, 50-54, 1995.

Singh, H. B., Anderson, B. E., Brune, W. H., Cai, C., Crawford, J. H., Cohen, R. C., Czech, E. P., Emmons, L., Fuelberg, H. E., Huey, G., Jacob, D. J., Jimenez, J. L., Kondo, Y., Kaduwela, A., Mao, J., Olson, J. R., Sachse, G. W., Vay, S. A., Weinheimer, A., Wennberg, P. O., Wisthaler, A., and the ARCTAS Science Team: Pollution influences on atmospheric composition and chemistry at high northern latitudes: Boreal and California forest fire emissions, Atmos. Environ., 44, 4553-4564, doi:10.1016/j.atmosenv.2010.08.026, 2010.

Simoneit, B. R. T.: Biomass burning - a review of organic tracers for smoke from incomplete combustion, Appl. Geochem., 17, 129-162, 2002.

Simpson, I. J., Akagi, S. K., Barletta, B., Blake, N. J., Choi, Y., Diskin, G. S., Fried, A., Fuelberg, H. E., Meinardi, S., Rowland, F. S., Vay, S. A., Weinheimer, A. J., Wennberg, P. O., Wiebring, P., Wisthaler, A., Yang, M., Yokelson, R. J., and Blake, D. R.: Boreal forest fire emissions in fresh Canadian smoke plumes: $\mathrm{C}_{1}-\mathrm{C}_{10}$ volatile organic compounds (VOCs), $\mathrm{CO}_{2}, \mathrm{CO}, \mathrm{NO}_{2}$, $\mathrm{NO}, \mathrm{HCN}$ and $\mathrm{CH}_{3} \mathrm{CN}$, Atmos. Chem. Phys. Discuss., 11, 95159566, doi:10.5194/acpd-11-9515-2011, 2011.

Sinha, P., Hobbs, P. V., Yokelson, R. J., Blake, D. R., Gao, S., and Kirchstetter, T. W.: Emissions from miombo woodland and dambo grassland savanna fires, J. Geophys. Res., 109, D11305, doi:10.1029/2004JD004521, 2004.

Sinha, P., Hobbs, P. V., Yokelson, R. J., Bertschi, I. T., Blake, D. R., Simpson, I. J., Gao, S., Kirchstetter, T. W., and Novakov, T.: Emissions of trace gases and particles from savanna fires in southern Africa, J. Geophys. Res., 108, 8487, doi:10.1029/2002JD002325, 2003.

Smil, V.: Energy flows in the developing world, Am. Sci., 67, 522531, 1979.

Smith, K. R., Pennise, D. M., Khummongkol, P., Chaiwong, V., Ritgeen, K., Zhang, J., Panyathanya, W., Rasmussen, R. A., and Khalil, M. A. K.: Greenhouse gases from small-scale combustion devices in developing countries: Charcoal-making kilns in Thailand, U.S. EPA Rep. EPA-600/R-99-109, Natl. Risk Manage. Res. Lab., Research Triangle Park, N. C., 1999. 
Smith, K., Uma, R., Kishore, V. V. N., Lata, K., Joshi, V., Zhang, J., Rasmussen, R. A., and Khalil, M. A. K.: Greenhouse gases from small-scale combustion devices in developing countries: Household stoves in India, Rep. EPA-600/R-00-052, U.S. Environ. Prot. Agency, Research Triangle Park, N. C., 2000.

Smith, R., Adams, M., Maier, S., Craig, R., Kristina, A., and Maling, I.: Estimating the area of stubble burning from the number of active fires detected by satellite, Remote Sens. Environ., 109(1), 95-106, 2007.

Snyder, J. R.: The impact of wet season and dry season prescribed fires on Miami Rock Ridge pinelands, Everglades National Park, South Florida Resource Center Technical Report SFRC 86-06, Homestead, FL, 1986.

Stocks, B. J.: The extent and impact of forest fires in northern circumpolar countries, in: Global Biomass Burning: Atmospheric, Climatic, and Biospheric Implications, edited by: Levine, J. S., MIT Press, Cambridge, MA, 1991.

Sudo, K. and Akimoto, H.: Global source attribution of tropospheric ozone: Long-range transport from various source regions, J. Geophys. Res., 112 D12302, doi:10.1029/2006JD007992, 2007.

Susott, R. A., Ward, D. E., Babbitt, R. E., and Latham, D. J.: The measurement of trace emissions and combustion characteristics for a mass fire, in: Global Biomass Burning: Atmospheric, Climatic, and Biospheric Implications, edited by: Levine, J. S., MIT Press, Cambridge, 245-257, 1991.

Susott, R. A., Olbu, G. J., Baker, S. P., Ward, D. E., Kauffman, J. B., and Shea, R. W.: Carbon, hydrogen, nitrogen, and thermogravimetric analysis of tropical ecosystem biomass, in: Biomass Burning and Global Change, edited by: Levine, J. S., MIT Press, Cambridge, 350-360, 1996.

Tabazadeh, A., Yokelson, R. J., Singh, H. B., Hobbs, P. V., Crawford, J. H., and Iraci, L. T.: Heterogeneous chemistry involving methanol in tropospheric clouds, Geophys. Res. Lett., 31, L06114, doi:10.1029/2003GL018775, 2004.

Thornton, J. A., Kercher, J. P., Riedel, T. P., Wagner, N. L., Cozic, J., Holloway, J. S., Dubé, W. P., Wolfe, G. M., Quinn, P. K., Middlebrook, A. M., Alexander, B., and Brown, S. S.: A large atomic chlorine source inferred from mid-continental reactive nitrogen chemistry, Nature, 464, 271-274, 2010.

Trentmann, J., Yokelson, R. J., Hobbs, P. V., Winterrath, T., Christian, T. J., Andreae, M. O., and Mason, S. A.: An analysis of the chemical processes in the smoke plume from a savanna fire, J. Geophys. Res., 110, D12301, doi:10.1029/2004JD005628, 2005.

USEPA: Compilation of air pollutant emission factors Volume I: Stationary point and area sources, AP-42, Office of Air Quality Planning and Standards, Office of Air and Radiation, Research Triangle Park, NC, 26 pp., 1995.

Val Martín, M., Honrath, R. E., Owen, R. C., Pfister, G., Fialho, P., and Barata, F.: Significant enhancements of nitrogen oxides, black carbon, and ozone in the North Atlantic lower free troposphere resulting from North American boreal wildfires, J. Geophys. Res., 111, D23S60, doi:10.1029/2006JD007530, 2006.

Val Martin, M., Logan, J. A., Kahn, R. A., Leung, F.-Y., Nelson, D. L., and Diner, D. J.: Smoke injection heights from fires in North America: analysis of 5 years of satellite observations, Atmos. Chem. Phys., 10, 1491-1510, doi:10.5194/acp-10-14912010, 2010.

van der Werf, G. R., Randerson, J. T., Giglio, L., Collatz, G. J.,
Kasibhatla, P. S., and Arellano Jr., A. F.: Interannual variability in global biomass burning emissions from 1997 to 2004, Atmos. Chem. Phys., 6, 3423-3441, doi:10.5194/acp-6-3423-2006, 2006.

van der Werf, G. R., Randerson, J. T., Giglio, L., Collatz, G. J., Mu, M., Kasibhatla, P. S., Morton, D. C., DeFries, R. S., Jin, Y., and van Leeuwen, T. T.: Global fire emissions and the contribution of deforestation, savanna, forest, agricultural, and peat fires (19972009), Atmos. Chem. Phys., 10, 11707-11735, doi:10.5194/acp10-11707-2010, 2010.

Veres, P., Roberts, J. M., Burling, I. R., Warneke, C., de Gouw, J., and Yokelson, R. J.: Measurements of gas-phase inorganic and organic acids from biomass fires by negative-ion proton-transfer chemical-ionization mass spectrometry, J. Geophys. Res., 115, D23302, doi:10.1029/2010JD014033, 2010.

Verma, S., Worden, J., Pierce, B., Jones, D. B. A., Al-Saadi, J., Boersma, F., Bowman, K., Eldering, A., Fisher, B., Jourdain, L., Kulawik, S., and Worden, H.: Ozone production in boreal fire smoke plumes using observations from Tropospheric Emissions Spectrometer and the Ozone Monitoring Instrument, J. Geophys. Res., 114, D02303, doi:10.1029/2008JD010108, 2009.

Vermote, E., Ellicott, E., Dubovik, O., Lapyonok, T., Chin, M., Giglio, L., and Roberts, G.: An approach to measure global biomass burning emissions of organic and black carbon from MODIS fire Radiative power, J. Geophys. Res., 114, D18205, doi:10.1029/2008JD011188, 2009.

Ward, D. E. and Radke, L. F.: Emissions measurements from vegetation fires: A Comparative evaluation of methods and results, in: Fire in the Environment: The Ecological, Atmospheric and Climatic Importance of Vegetation Fires, edited by: Crutzen, P. J. and Goldammer, J. G., John Wiley, New York, 53-76, 1993.

Ward, D. E., Susott, R. A., Kauffman, J. B., Babbitt, R. E., Cummings, D. L., Dias, B., Holden, B. N., Kaufmann, Y. J., Rasmussen, R. A., and Setzer, A. W.: Smoke and fire characteristics for Cerrado and deforestation burns in Brazil: BASE-B experiment, J. Geophys. Res., 97, 14601-14619, 1992.

Warneke, C., Roberts, J. M., Veres, P., Gilman, J., Kuster, W. C., Burling, I., Yokelson, R. J., and de Gouw, J. A.: VOC identification and inter-comparison from laboratory biomass burning using PTR-MS and PIT-MS, Int. J. Mass Spectrom., IJMS-D-1000225, in press, 2011.

Wiedinmyer, C. and Hurteau, M. D.: Prescribed fire as a means of reducing forest carbon emissions in the Western United States, Environ. Sci. Technol., 44(6), 1926-1932, 2010.

Wiedinmyer, C., Akagi, S. K., Yokelson, R. J., Emmons, L. K., AlSaadi, J. A., Orlando, J. J., and Soja, A. J.: The Fire INventory from NCAR (FINN) - a high resolution global model to estimate the emissions from open burning, Geosci. Model Dev. Discuss., 3, 2439-2476, doi:10.5194/gmdd-3-2439-2010, 2010.

Wofsy, S. C., Sachse, G. W., Gregory, G. L., Blake, D. R., Bradshaw, J. D., Sandholm, S. T., Singh, H. B., Barrick, J. A., Harriss, R. C., Talbot, R. W., Shipham, M. A., Browell, E. V., Jacob, D. J., and Logan, J. A.: Atmospheric chemistry in the Arctic and subarctic: Influence of natural fires, industrial emissions, and stratospheric inputs, J. Geophys Res., 97, 16731-16746, 1992.

Yevich, R. and Logan, J. A.: An assessment of biofuel use and burning of agricultural waste in the developing world, Global Biogeochem. Cy., 17(4), 1095, doi:10.1029/2002GB001952, 2003.

Yokelson, R. J., Griffith, D. W. T., and Ward, D. E.: Open 
path Fourier transform infrared studies of large-scale laboratory biomass fires, J. Geophys. Res., 101(D15), 21067-21080, doi:10.1029/96JD01800, 1996.

Yokelson, R. J., Ward, D. E., Susott, R. A., Reardon, J., and Griffith, D. W. T.: Emissions from smoldering combustion of biomass measured by open-path Fourier transform infrared spectroscopy, J. Geophys. Res., 102(D15), 18865-18877, 1997.

Yokelson, R. J., Goode, J. G., Ward, D. E., Susott, R. A., Babbitt, R. E., Wade, D. D., Bertschi, I., Griffith, D. W. T., and Hao, W. M.: Emissions of formaldehyde, acetic acid, methanol, and other trace gases from biomass fires in North Carolina measured by airborne Fourier transform infrared spectroscopy, J. Geophys. Res., 104(D23), 30109-30126, doi:10.1029/1999JD900817, 1999.

Yokelson, R. J., Bertschi, I. T., Christian, T. J., Hobbs, P. V., Ward, D. E., and Hao, W. M.: Trace gas measurements in nascent, aged, and cloud-processed smoke from African savanna fires by airborne Fourier transform infrared spectroscopy (AFTIR), J. Geophys. Res., 108(D13), 8478, doi:10.1029/2002JD002322, 2003.

Yokelson, R. J., Karl, T., Artaxo, P., Blake, D. R., Christian, T. J., Griffith, D. W. T., Guenther, A., and Hao, W. M.: The Tropical Forest and Fire Emissions Experiment: overview and airborne fire emission factor measurements, Atmos. Chem. Phys., 7, 5175-5196, doi:10.5194/acp-7-5175-2007, 2007a.

Yokelson, R. J., Urbanski, S. P., Atlas, E. L., Toohey, D. W., Alvarado, E. C., Crounse, J. D., Wennberg, P. O., Fisher, M. E., Wold, C. E., Campos, T. L., Adachi, K., Buseck, P. R., and Hao, W. M.: Emissions from forest fires near Mexico City, Atmos. Chem. Phys., 7, 5569-5584, doi:10.5194/acp-7-5569-2007, 2007b.

Yokelson, R. J., Christian, T. J., Karl, T. G., and Guenther, A.: The tropical forest and fire emissions experiment: laboratory fire measurements and synthesis of campaign data, Atmos. Chem. Phys., 8, 3509-3527, doi:10.5194/acp-8-3509-2008, 2008.
Yokelson, R. J., Crounse, J. D., DeCarlo, P. F., Karl, T., Urbanski, S., Atlas, E., Campos, T., Shinozuka, Y., Kapustin, V., Clarke, A. D., Weinheimer, A., Knapp, D. J., Montzka, D. D., Holloway, J., Weibring, P., Flocke, F., Zheng, W., Toohey, D., Wennberg, P. O., Wiedinmyer, C., Mauldin, L., Fried, A., Richter, D., Walega, J., Jimenez, J. L., Adachi, K., Buseck, P. R., Hall, S. R., and Shetter, R.: Emissions from biomass burning in the Yucatan, Atmos. Chem. Phys., 9, 5785-5812, doi:10.5194/acp-9-5785-2009, 2009.

Yokelson, R. J., Burling, I. R., Urbanski, S. P., Atlas, E. L., Adachi, K., Buseck, P. R., Wiedinmyer, C., Akagi, S. K., Toohey, D. W., and Wold, C. E.: Trace gas and particle emissions from open biomass burning in Mexico, Atmos. Chem. Phys. Discuss., 11, 7321-7374, doi:10.5194/acpd-11-7321-2011, 2011.

Yu, Z., Loisel, J., Brosseau, D. P., Beilman, D. W., and Hunt, S. J.: Global peatland dynamics since the Last Glacial Maximum, Geophys. Res. Lett., 37, L13402, doi:10.1029/2010GL043584, 2010.

Zárate, I. O., Ezcurra, A., Lacaux, J. P., Van Dinh, P., and Díaz de Argandoña, J.: Pollution by cereal waste burning in Spain, Atmos. Res., 73, 161-170, 2005.

Zhang, J., Smith, K. R., Ma, Y., Ye, S., Jiang, F., Qi, W., Liu, P., Khalil, M. A. K., Rasmussen, R. A., and Thorneloe, S. A.: Greenhouse gases and other airborne pollutants from household stoves in China: a database for emission factors, Atmos. Environ., 34, 4537-4549, 2000.

Zuk, M., Rojas, L., Blanco, S., Serrano, P., Cruz, J., Angeles, F., Tzintzun, G., Armendariz, C., Edwards, R. D., Johnson, M., RiojasRodriguez, H., and Masera, O.: The impact of improved woodburning stoves on fine particulate matter concentrations in rural Mexican homes, J. Expo. Sci. Env. Epid., 17, 224-232, 2007. 